Nevada

Environmental

Restoration

Project

RECEIVED

FEB 131997

OSTI
DOE/NV-450

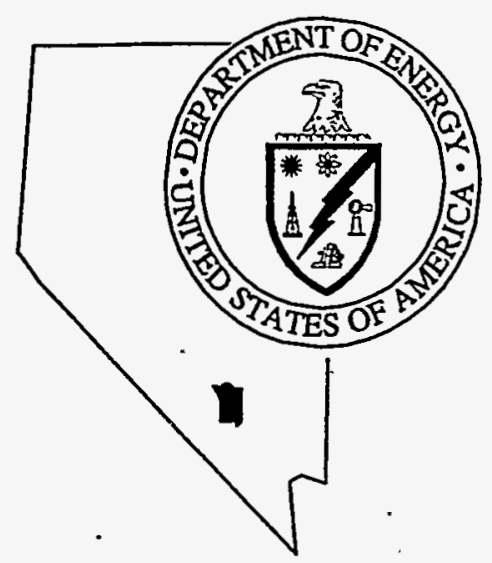

Corrective Action Investigation Plan for Central Nevada Test Area CAU No. 417

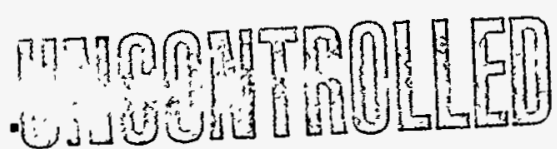

Controlled Copy No.: U.

January 1997

Environmental Restoration.

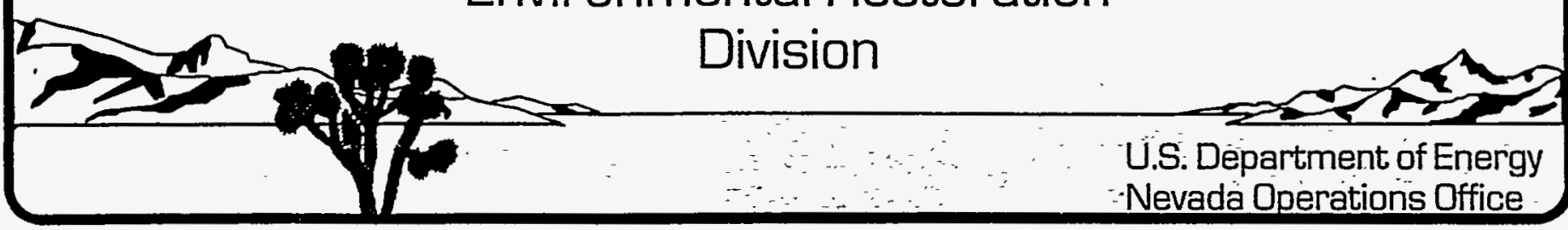




\section{CORRECTIVE ACTION INVESTIGATION PLAN FOR CENTRAL NEVADA TEST AREA CAU NO. 417}

DOE Nevada Operations Office Las Vegas, Nevada
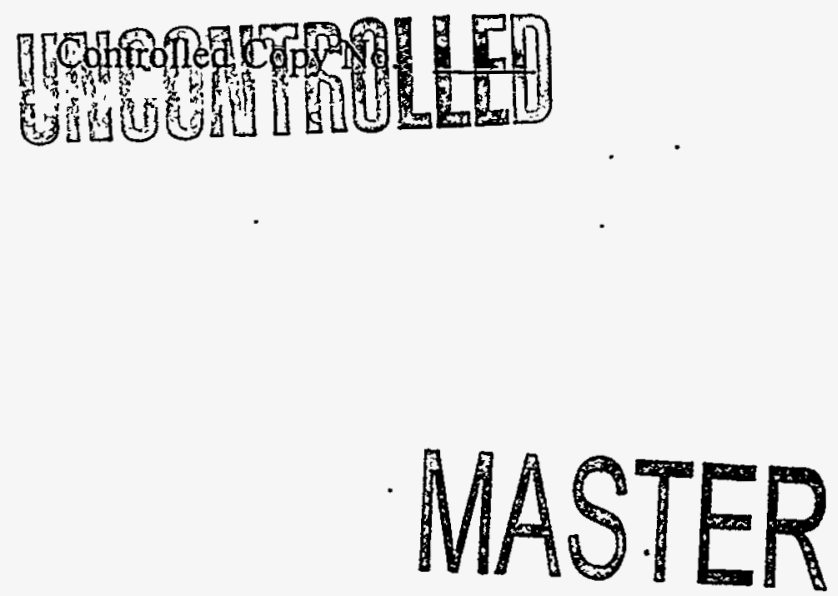

January 1997

DISTRIBUTION OF THIS DOCUMENT IS UNLIMTTED 


\section{CORRECTIVE ACTION INVESTIGATION PLAN FOR CENTRAL NEVADA TEST AREA \\ CAU NO. 417}

\section{DISCLAIMER}

This report was prepared as an account of work sponsored by an agency of the United States Government. Neither the United States Government nor any agency thereof, nor any of their employees, makes any warranty, express or implied, or assumes any legal liability or responsibility for the accuracy, completeness, or usefulness of any information, apparatus, product, or process disclosed, or represents that its use would not infringe privately owned rights. Reference herein to any specific commercial product, process, or service by trade name, trademark, manufacturer, or otherwise does not necessarily constitute or imply its endorsement, recomI mendation, or favoring by the United States Government or any agency thereof. The views and opinions of authors expressed herein do not necessarily state or reflect those of the United States Government or any agency thereof:- -

Approved by: Babive T. Curtis. for Janet Appenzeller-Wing, Project Manager, Offsites Subproject
Date: $1 / 17 / 97$

Date: $\frac{1117197}{3}$

Stephen A. Mellington, Project Manager,

Nevada Environmental Restoration Project 


\section{Table of Contents}

List of Figures iv

List of Tables vi

List of Acronyms and Abbreviations vii

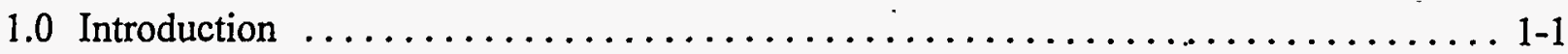

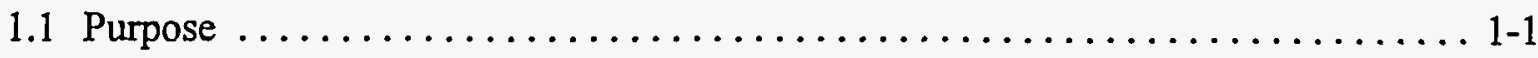

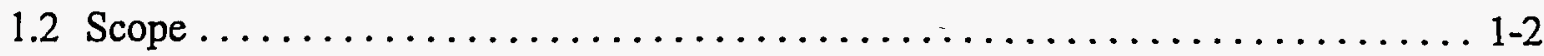

1.3 Federal Facility Agreement and Consent Order Requirements $\ldots \ldots \ldots \ldots \ldots \ldots$ 1-2

1.4 Expedited Site Characterization Methodology $\ldots \ldots \ldots \ldots \ldots \ldots \ldots \ldots \ldots \ldots$. $\ldots \ldots$

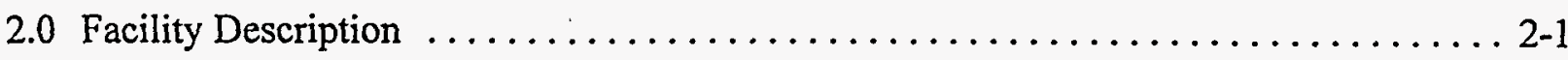

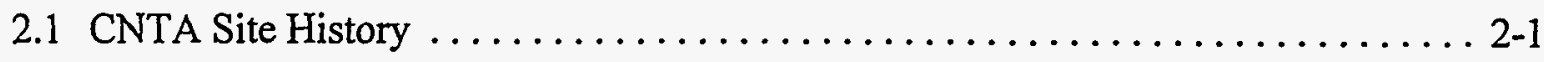

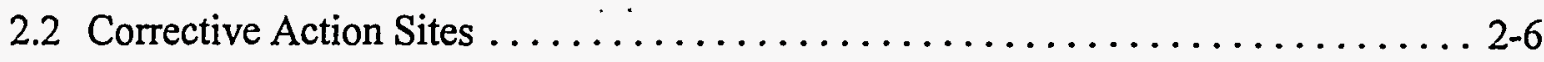

2.2.1 Decontamination Facility Pit at UC-1 $\ldots \ldots \ldots \ldots \ldots \ldots \ldots \ldots \ldots \ldots \ldots \ldots$

2.2.2 Waste Piles ........................... 2-7

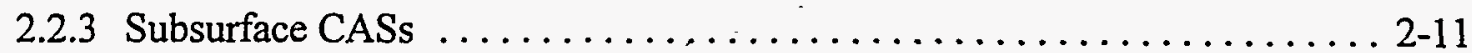

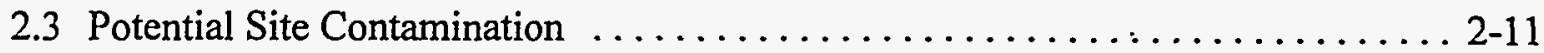

2.3.1 Potential Soil Contamination . . . . . . . . . . . . . . . 2-11

2.3.1.1 Central Mud Pit . . ...................... 2-11

2.3.1.2 Additional Mud Pits at UC-1, UC-3, and UC-4 . . . . . . . 2-11

2.3.1.3 Shaker Pad Areas . . . . . . . . . . . . . . . . 2-14

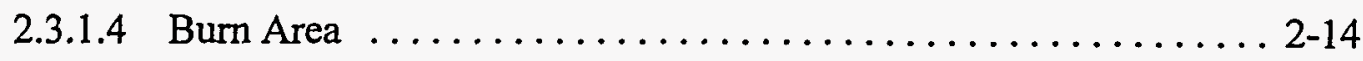

2.3.1.5 Scrap and Trash Dump $\ldots \ldots \ldots \ldots \ldots \ldots \ldots \ldots \ldots \ldots \ldots \ldots \ldots \ldots \ldots . .18$

2.3.1.6 Drilling Mud/Grout Piles and Drill Mud/Grout Spill Area . . . . . . 2-18

2.3.1.7 Protruding Pipes $\ldots \ldots \ldots \ldots \ldots \ldots \ldots \ldots \ldots \ldots \ldots \ldots \ldots \ldots \ldots \ldots \ldots \ldots \ldots \ldots \ldots .18$

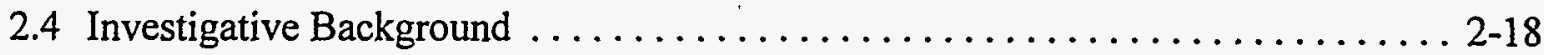

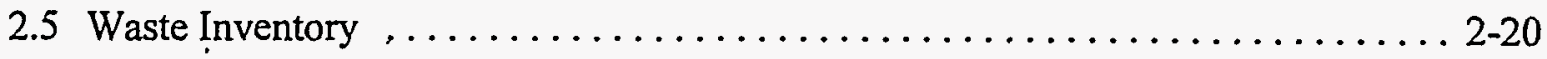

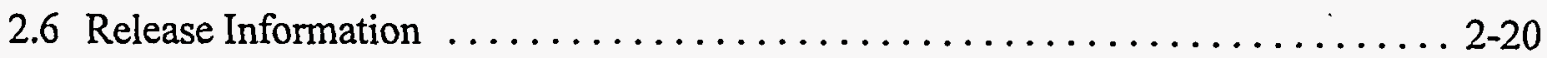




\section{Table of Contents (Continued)}

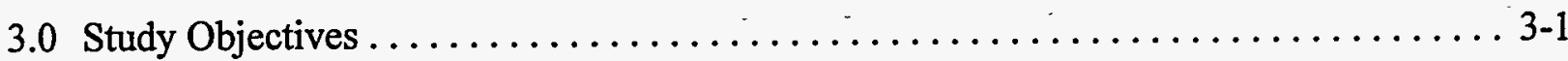

3.1 Corrective Action Site Groups $\ldots \ldots \ldots \ldots \ldots \ldots \ldots \ldots \ldots \ldots \ldots \ldots . . \ldots \ldots . . \ldots \ldots$

3.1.1 Mud Pits, Shaker Pad Areas and Drilling Mud/Grout Piles ........... 3-1

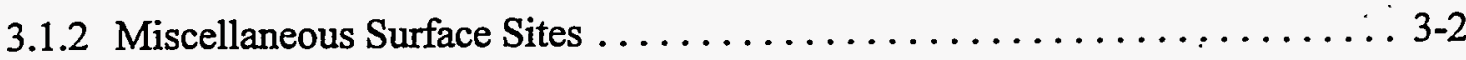

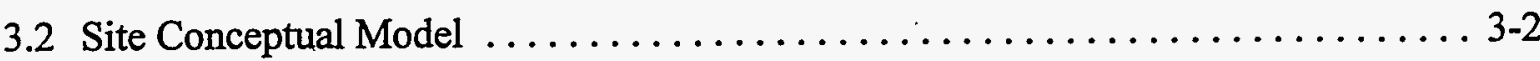

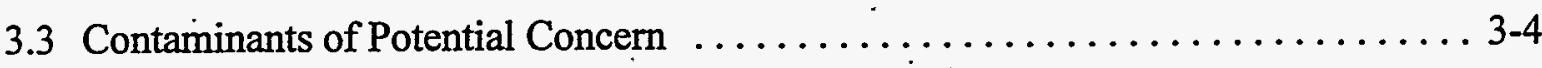

3.3.1 Mud Pits, Shaker Pad Areas, and Drilling Mud/Grout Piles .......... 3-4

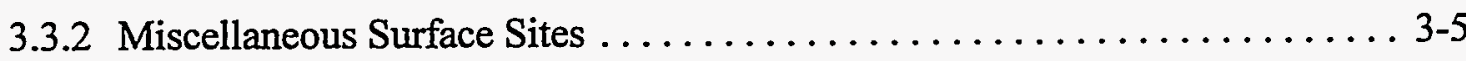

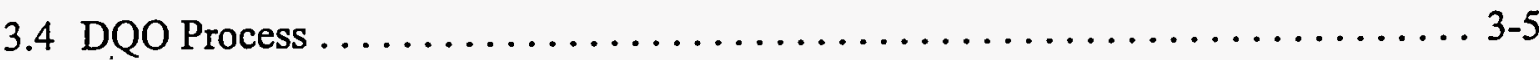

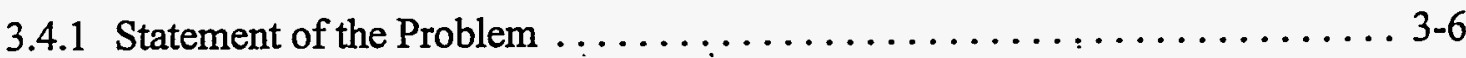

3.4.1.1 Mud Pits, Shaker Pad Areas, and Drilling Mud/Grout Piles ...... 3-6

3.4.1.2 Miscellaneous Surface Sites ................... 3-6

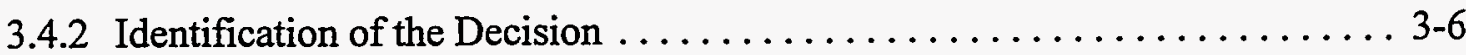

3.4.2.1 Mud Pits, Shaker Pad Areas, and Drilling Mud/Grout Piles ...... 3-6

3.4.2.2 Miscellaneous Surface Sites . .................. 3-7

3.4.3 Identification of Inputs to the Decision $\ldots \ldots \ldots \ldots \ldots \ldots \ldots \ldots \ldots .3-7$

3.4.3.1 Mud Pits, Shaker Pad Areas, and Drilling Mud/Grout Piles ...... 3-7

3.4.3.2 Miscellaneous Surface Sites $\ldots \ldots \ldots \ldots \ldots \ldots \ldots \ldots \ldots . . \ldots \ldots .7$

3.4.3.3 Preliminary Action Levels $\ldots \ldots \ldots \ldots \ldots \ldots \ldots \ldots \ldots \ldots . . \ldots \ldots$

3.4.3.4 Measurement Objectives ......................... 3-9

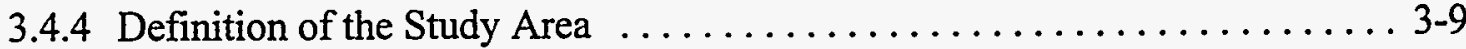

3.4.4.1 Mud Pits, Shaker Pad Areas, and Drilling Mud/Grout Piles .... . . 3-9

3.4.4.2 Miscellaneous Surface Sites .................... 3-11

3.4.5 Developmient of Decision Rules . ...................... 3-12

3.4.5.1 Mud Pits, Shaker Pad Areas, and Drilling Mud/Grout Piles .... . 3-12

3.4.5.1.1 Mud Pits ....................... 3-12

3.4.5.1.2 Shaker Pad Areas and Mud/Grout Piles ......... 3-14

3.4.5.1.3 Drilling Mud/Grout Piles ................ 3-14

3.4.5.2 Miscellaneous Surface Sites ................... 3-14

3.4.5.3 Additional Decision Rules .................... 3-14

3.4.6 Specification of Limits on Decision Errors $\ldots \ldots \ldots \ldots \ldots \ldots \ldots \ldots \ldots . . \ldots \ldots$

3.4.6.1 Mud Pits, Shaker Pad Areas, and Drilling Mud/Grout Piles . . . . 3 3-15 


\section{DISCLAIMER}

Portions of this document may be illegible in electronic image products. Images are produced from the best available original document. 


\section{Table of Contents (Continued)}

3.4.7 Optimization of the Design for Obtaining Data ............... 3-16

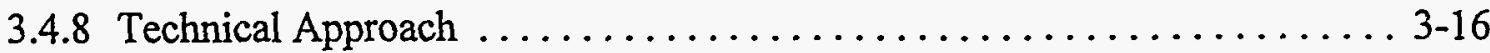

4.0 Corrective Action Investigation Sampling and Analysis Tasks $\ldots \ldots \ldots \ldots \ldots \ldots$ 4-1

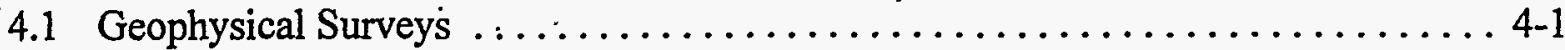

4.2 Mud Pits, Shaker Pad Areas, and Drilling Mud/Grout Piles Investigation . . . . . 4-2

4.2.1 Mud Pits . ................................. 4-2

4.2.2 Shaker Pad Area Investigation $\ldots \ldots \ldots \ldots \ldots \ldots \ldots \ldots \ldots \ldots \ldots$. 4-9

4.2.3 Drilling Mud/Grout Piles ......................... 4-10

4.2.4 Potential Underground Storage Tanks $\ldots \ldots \ldots \ldots \ldots \ldots \ldots \ldots \ldots . . \ldots \ldots \ldots$

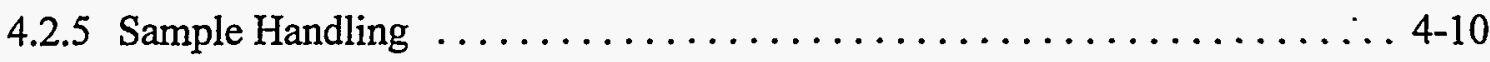

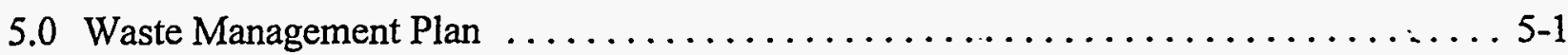

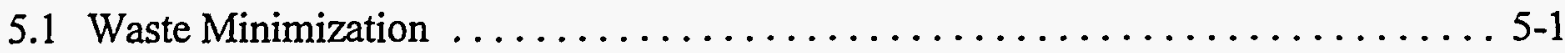

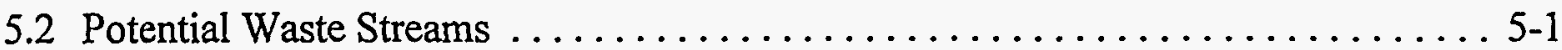

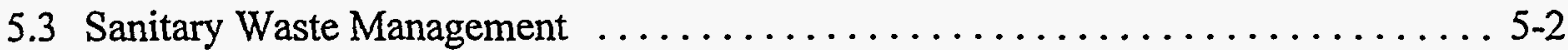

5.4 Low-Level Waste Management $\ldots \ldots \ldots \ldots \ldots \ldots \ldots \ldots \ldots \ldots \ldots \ldots \ldots \ldots \ldots \ldots \ldots \ldots .2$

5.5 Hazardous Waste Management ............................ 5-2

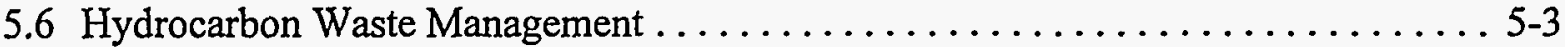

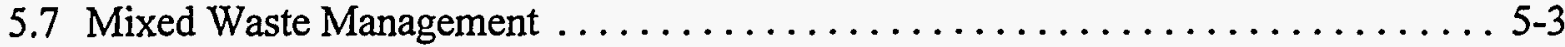

6.0 Time Frame and Reporting $\ldots \ldots \ldots \ldots \ldots \ldots \ldots \ldots \ldots \ldots \ldots \ldots \ldots \ldots \ldots \ldots, 6 \ldots \ldots, 1$

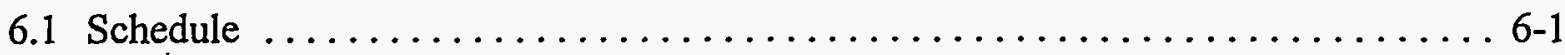

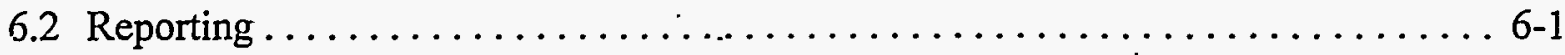

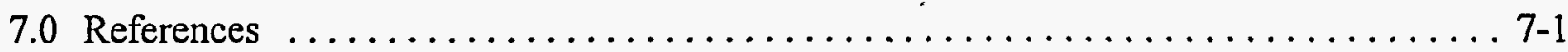

Appendix A - Expedited Site Characterization Core Team Description ............. A-1

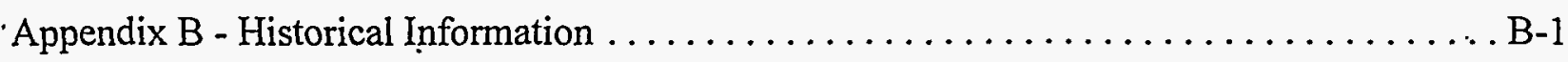

Appendix C - Sampling and Analysis Design $\ldots \ldots \ldots \ldots \ldots \ldots \ldots \ldots \ldots \ldots \ldots \ldots \ldots \ldots \ldots$ 


\section{List of Figures}

Number

Title

Page

2-1 Site Map, Central Nevada Test Area, Nye County, Nevada

2-2 Boring and Well Locations, Central Nevada Test Area

2-3 Decontamination Facility Pit at UC-1, Plan and Section, Central Nevada Test Area

2-4 Corrective Action Sites in the Vicinity of the Central Mud Pit, Central Nevada Test Area

2-5 Mud Pits at UC-1, Central Nevada Test Area ................ 2-13

2-6 Corrective Action Sites in the Vicinity of the UC-3 Emplacement Well, Central Nevada Test Area

2-7 Corrective Action Sites in the Vicinity of the UC-4 Emplacement Well, Central Nevada Test Area

2-8 UC-3 and UC-4 Mud Pits, Central Nevada Test Area

2-9 Additional Corrective Action Sites in the Vicinity of the UC-3

Emplacement Well, Central Nevada Test Area

3-1 Sampling Flowchart, Central Nevada Test Area Mud Pits $3-13$

4-1 Sampling Locations, Central Mud Pit 4-3

4-2 Sampling Locations, Additional Mud Pits at UC-1 4-4 


\section{List of Figures (Continued)}

Number

Title

Page

4-3 Sampling Locations, UC-1 Mud Pits

. 4-5

4-4 Sampling Locations, UC-3 Mud Pits $4-6$

4-5 Sampling Locations, UC-4 Mud Pits 4-7

V

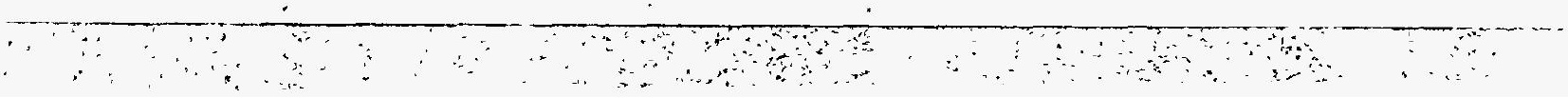




\section{List of Tables}

Number

Title

Page

1-1 Federal Facility Agreement and Consent Order

Requirements/Corrective Action Investigation Plan Crosswalk

2-1 Corrective Action Sites

2-2 Analytical Data from the 1986 REECo Survey

2-3 Central Mud Pit and UC-4 Mud Pit 1995 Analytical Results $2-22$

3-1 CNTA Mud Pits, Shaker Pad Areas, and Drilling Mud/Grout Piles Investigation Measurement Objectives

4-1 CNTA Surface Sites Sampling Requirements 4-9 


\section{List of Acronyms and Abbreviations}

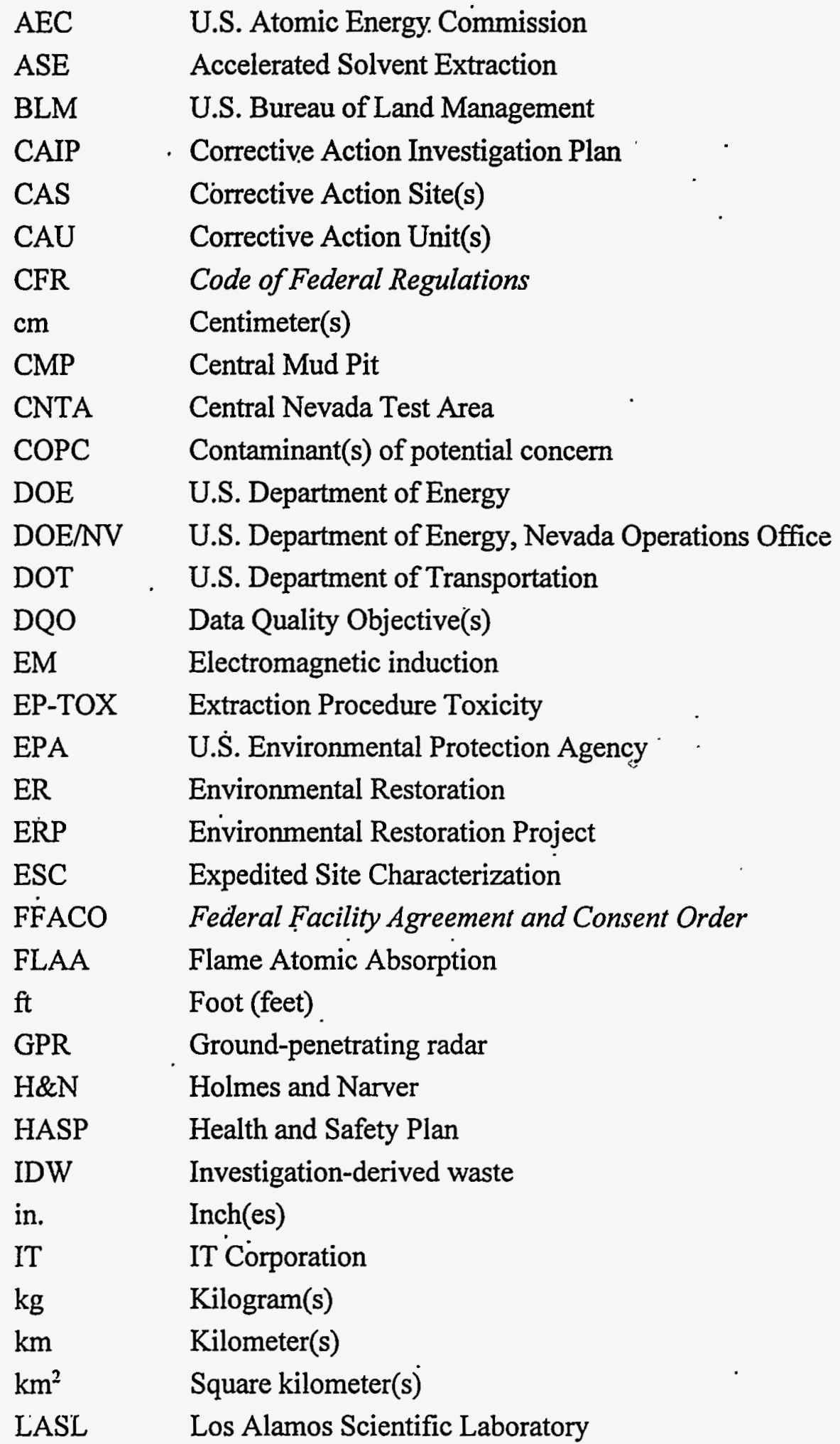




\section{List of Acronyms and Abbreviations (Continued)}

$\begin{array}{ll}\text { LLNL } & \text { Lawrence Livermore National Laboratory } \\ \text { LLW } & \text { Low-level waste } \\ \text { LTHMP } & \text { Long-Term Hydrologic Monitoring Program } \\ \mathrm{m} & \text { Meter(s) } \\ \mathrm{MDL} & \text { Minimum detectable level; also method detection limit } \\ \mathrm{mg} / \mathrm{kg} & \text { Milligram(s) per kilogram } \\ \mathrm{mg} / \mathrm{L} & \text { Milligram(s) per liter } \\ \mathrm{mi} & \text { Mile(s) } \\ \mathrm{mi}{ }^{2} & \text { Square mile(s) } \\ \mathrm{NDEP} & \text { Nevada Division of Environmental Protection } \\ \mathrm{NS} & \text { Not specified } \\ \mathrm{NTS} & \text { Nevada Test Site } \\ \mathrm{oz} & \text { Ounce } \\ \mathrm{pCi} / \mathrm{g} & \text { PicoCurie(s) per gram } \\ \mathrm{PE} & \text { Performance evaluation } \\ \mathrm{PPE} & \text { Personal protective equipment } \\ \mathrm{ppm} & \text { Part(s) per million } \\ \text { QA/QC } & \text { Quality assurance/quality control } \\ \text { QAPP } & \text { Quality Assurance Project Plan } \\ \text { RCRA } & \text { Resource Conservation and Recovery Act } \\ \text { REECo } & \text { Reynolds Electrical \& Engineering Co., Inc. } \\ \text { RPD } & \text { Relative percent difference } \\ \text { RSD } & \text { Relative standard deviation } \\ \text { RSL } & \text { Remote Sensing Laboratory } \\ \text { SGZ } & \text { Surface ground zero } \\ \text { SSL } & \text { Soil screening level } \\ \text { TBD } & \text { To be determined } \\ \text { TCLP } & \text { Toxicity Characteristics Leaching Procedure } \\ \text { TPH } & \text { Total petroleum hydrocarbon(s) } \\ \text { UST } & \text { Underground storage tank(s) } \\ \text { XRF } & \text { X-ray fluorescence } \\ { }^{\circ} \mathrm{C} & \text { Degree(s) Celcius } \\ \mu \mathrm{g} / \mathrm{kg} & \text { Microgram(s) per kilogram } \\ \% \mathrm{R} & \text { Percent recovery } \\ & \end{array}$




\subsection{Introduction}

This Corrective Action Investigation Plan (CAIP) is part of a U.S. Department of Energy (DOE)funded environmental investigation of the Central Nevada Test Area (CNTA) (Corrective Action Units [CAUs] No. 4.17 and 443). The CNTA is located in Hot Creek Valley in Nye County, Nevada, adjacent to U.S. Highway 6, about 15 kilometers $(\mathrm{km})(10$ miles [mi]) northeast of Warm Springs. The CNTA was the site of Project Faultless, a nuclear device detonated in the subsurface by the U.S. Atomic Energy Commission (AEC) in January 1968. The purpose of this test was to gauge the seismic effects of relatively large, high-yield detonations completed outside of the Nevada Test Site (NTS). The test was also used to determine the suitability of the site for future large detonations. The yield of the Faultless test was between 200 kilotons and 1 megaton (DOE, 1994c). Two other similar tests were planned for the CNTA, but neither one of them was completed (AEC, 1974).

This CAIP is prepared in a manner consistent with the principals of Expedited Site Characterization (ESC) which applies techniques such as on-site analytical facilities, on-site data management and interpretation, and a dynamic (flexible) work plan in order to minimize the potential for subsequent work episodes. Section 1.4 provides a more detailed discussion of the ESC method.

This CAIP is designed and will be implemented in accordance with the Federal Facility Agreement and Consent Order (FFACO) completed for the NTS and related DOE sites, including the CNTA (FFACO, 1996), the Industrial Sites Quality Assurance Project Plan (QAPP) (DOE, 1996), and all applicable Nevada Division of Environmental Protection (NDEP) policies and regulations.

\subsection{Purpose}

This CAIP consists of a surface investigation. The purpose of the surface investigation is to characterize 15 identified Corrective Action Sites (CASs) associated with the installation and post-shot subsurface testing at the CNTA. If contamination is found at any of the 15 surface CASs, the extent of contamination will be determined in order to develop an appropriate corrective action. 


\subsection{Scope}

The scope of the CNTA corrective action investigation includes the following elements:

- Surface geophysical surveys

- Sampling and analysis of potentially contaminated soil

Each of these elements is outlined in detail in Sections 3.0 and 4.0 of this plan.

\subsection{Federal Facility Agreement and Consent Order Requirements}

The FFACO requires that CAIPs include or reference the following components needed to conduct an investigation:

- Project Management

- Technical

- Quality Assurance/Quality Control

- Health and Safety

- Public Involvement

- Field Sampling, as applicable

- Waste Management, as applicable

Six of the seven components are discussed in other site-specific project documents. Project Management protocol is discussed in the DOE Nevada Operations Office (DOE/NV) Environmental Restoration Project (ERP) Project Management Plan (DOE, 1994b). Field and laboratory Quality Assurance and Quality Control $(\mathrm{QA} / \mathrm{QC})$ procedures applicable to the CNTA investigation are detailed in the Industrial Sites QAPP (DOE, 1996) and the site-specific QA Plan for the on-site laboratory. Additional field QA/QC procedures are discussed in contractorspecific procedures, and the Health and Safety aspects of this project are documented in the DOE/NV Environmental Restoration Project Health and Safety Plan (HASP) (DOE, 1994a) and will also be supplemented by a site-specific HASP written prior to commencement of field work. Public involvement is documented in the draft Public Involvement Plan for the NTS which, when finalized, will be incorporated as Appendix V of the FFACO. Technical, field sampling activities and methods are detailed in Section 4.0, and investigation-derived waste (IDW) management is discussed in Section 5.0 of this CAIP. A crosswalk between the FFACO requirements and the contents of this CAIP is presented in Table 1-1. 
Table 1-1

. Federal Facility Agreement and Consent Order Requirements/Corrective Action Investigation Plan Crosswalk

\begin{tabular}{||l|l||}
\hline \multicolumn{1}{|c|}{ FFACO Requirement } & \multicolumn{1}{|c|}{ Where the Requirement is Met } \\
\hline \multirow{2}{*}{ Projėct Management } & DOE/NV ERP Project Management Plan \\
\cline { 2 - 3 } & CAIP - Time Frame Schedule - Section 6.0 \\
\hline Technical & CAIP - Sections 3.0, 4.0, and Appendix C \\
\hline Quality Assurance/Quality Control & Industrial Sites QAPP and Contractor Procedures \\
\hline \multirow{2}{*}{ Health and Safety } & DOE/NV ERP Health and Safety Plan \\
\cline { 2 - 3 } & Site-Specific Health and Safety Plans \\
\hline Public Involvement & Draft Public Involvement Plan \\
\hline Field Sampling & CAIP - Section 4.0 \\
\hline Waste Management & CAIP - Section 5.0 \\
\hline Time Frame & CAIP - Section 6.0 \\
\hline
\end{tabular}

\subsection{Expedited Site Characterization Methodology}

The ESC methodology incorporates on-site decision-making technologies that permit site characterization to be completed in one continuous phase. It has been demonstrated that the characterization phase can be streamlined, without compromising data quality. By using on-site analytical technologies, the need to send nearly all samples off site is minimized. By providing on-site decision-making capability, the ESC methodology can significantly reduce the probability of having to return to the site to fill data gaps. As a result, the current multiphase time sequence of data acquisition (consisting of sampling, analyzing, evaluating, and planning that typically takes years) becomes compressed into a single real-time phase, requiring only months to complete. Because each new piece of information is dictated by analysis of all past data, its information content is maximized. The result is not only quicker but more effective site characterization. 
The on-site decision-making component of ESC is implemented by a core team of mid- to senior-level personnel with extensive experience and training in the scientific disciplines applicable for the site. A description of the roles and responsibilities of this core team is presented in Appendix A. 


\subsection{Facility Description .}

This section presents a summary of site information excerpted from the following historical documents (see Section 7.0 for full reference information):

- U.S. Atomic Energy Commission, Planning Directive:" Demobilization, Restoration, and Monitoring, CNTA

- U.S. Atomic Energy Commission, Summary Report: CNTA Demobilization and Restoration Activities

- Eberline Instrument Corporation, Radiation Contamination Clearance Report for CNTA, prepared for AEC

- Reynolds Electrical \& Engineering Co., Inc., Hazardous Waste Installation Assessment Report

- Desert Research Institute, Preliminary Assessment of DOE's Nevada Operations Office Nuclear Weapons Testing Area

Additional information was obtained from historical and recent aerial photographs of the CNTA obtained from the DOE Nevada Operations Office Remote Sensing Laboratory (RSL), operated by Bechtel Nevada (RSL, 1968; RSL, 1993). The site photographs were reviewed by DOE and IT Corporation (IT) concurrently with a site reconnaissance visit on Febiuary 13 and 14, 1996.

\subsection{CNTA Site History}

The CNTA consisted of several separate land withdrawals, land easements, and special land-use permits obtained by the AEC from the U.S. Bureau of Land Management (BLM). For the Faultless device emplacement boring (UC-1), a 2.59-square kilometer $\left(\mathrm{km}^{2}\right)$ (one square mile $\left[\mathrm{mi}^{2}\right]$ ) land withdrawal was formalized between the AEC and BLM on December 6, 1968, under Public Land Order \#4338. Subsequent additional withdrawals were made for emplacement borings UC-3 and UC-4 on December 2, 1969, under Public Land Order \#4748. The withdrawals for the UC-3 and UC-4 sites are larger than the UC-1 site by about $1.30 \mathrm{~km}^{2}$ $\left(0.5 \mathrm{mi}^{2}\right)$. Other permits and easements were obtained for exploratory borings, weather stations, and miscellaneous support facilities in Hot Creek Valley, such as Contract AT(26-1)552. This contract was negotiated with Nye County for a 91.4-meter (m) square (300-foot [ft] square) area 
on an aircraft parking apron at the Tonopah Airport. The CNTA consisted of about 20 separate properties (AEC, 1974).

Under the direction of the AEC, CNTA was operated and maintained by Holmes and Narver $(H \& N)$ and its subcontractors. Other federal agencies assisted in the operations, including:

- National Environmental Research Center (formerly the U.S. Public Health Service)

- Air Resources Laboratory (formerly the U.S. Weather Bureau)

- U.S. Geological Survey

- National Ocean Survey

Scientific programs at CNTA, implemented by AEC subcontractors, were jointly administered by Lawrence Livermore National Laboratory (LLNL) and Los Alamos Scientific Laboratory (LASL).

The Project Faultless facilities consisted of a Base Camp and a separate Control Point area (Figure 2-1). Originally, the Base Camp was a temporary H\&N support camp, but during 1968 and 1969 after the Faultless project, the Base Camp and the Control Point areas were improved for reuse. Selected facilities were purchased from H\&N; new buildings were constructed, and other buildings were replaced with portable trailers from the NTS (AEC, 1974).

Emplacement boring UC-1 was completed about $35 \mathrm{~km}$ (25 mi) north of Base Camp at Nevada State coordinates (central zone) North 1,414,340 feet, East 629,000 feet. The boring was advanced through about $700 \mathrm{~m}(2,300 \mathrm{ft})$ of alluvium and penetrated a confined aquifer in volcanic tuff. The two additional emplacement borings (UC-3 and UC-4) were also completed, as planned, about $4.8 \mathrm{~km}$ (3 mi) to the north (UC-4) and south (UC-3) of UC-1. Emplacement boring UC-3 and additional support facilities were to be used for Project Adagio, but the project was never completed. In addition, several other structures were built for the Adagio project, including a new control point, an airstrip, an access road system, a recording trailer park, cableways, and a ground zero area. Similarly, emplacement hole UC-4 was to be used for a future project (unnamed), but the project was never completed (AEC, 1974). 


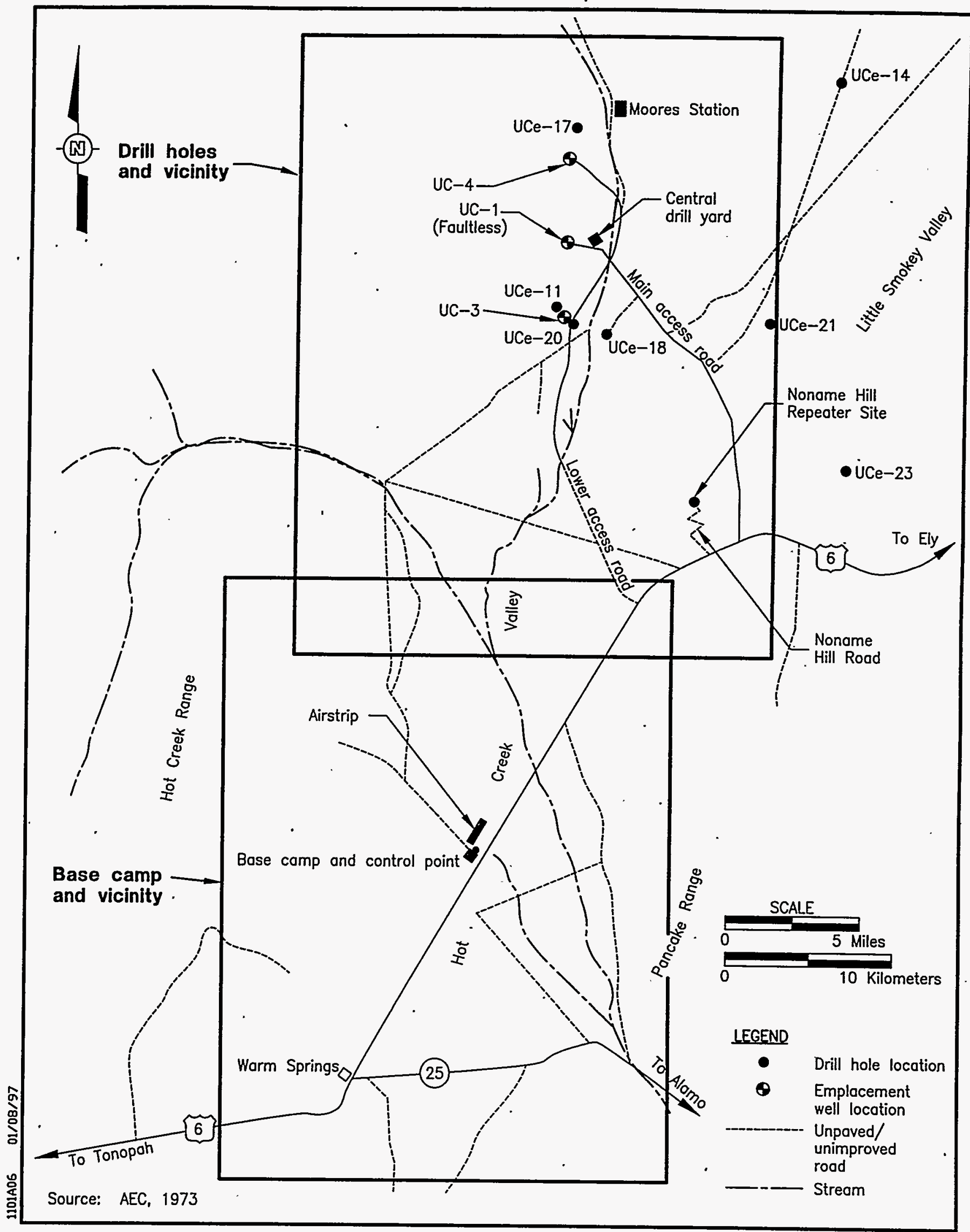

Figure 2-1

Site Map,

Central Nevada Test Area, Nye County, Nevada 2-3. 
Large-diameter, deep boreholes were completed for the emplacement borings. Boring UC-1 is a 1.8-m (72-inch [in.]) to 1.0-m (42-in.) diameter borehole advanced to $998 \mathrm{~m}(3,275 \mathrm{ft})$ below grade. It is cased from grade to about $122 \mathrm{~m}$ (400 ft) below grade with $1.2-\mathrm{m}$ (48-in.) and $0.27-\mathrm{m}$ (10.75-in.) casing. Boring UC-3 is a 3-m (120-in.) diameter borehole advanced to $1,477 \mathrm{~m}(4,846 \mathrm{ft})$ below grade. UC-3 is cased from grade to $1,458 \mathrm{~m}(4,782 \mathrm{ft})$ below grade with $1.3-\mathrm{m}$ (54-in.) casing. Boring UC-4 is a 3.6-m (144-in.) to 3-m (120-in.) diameter borehole advanced to $1,676 \mathrm{~m}(5,500 \mathrm{ft})$ below grade. UC-4 is cased with 3.1-m (122-in.) casing from grade to $127 \mathrm{~m}$ ( $415 \mathrm{ft}$ ) below grade and is uncased from that depth to the bottom (Fenix and Scisson, 1973).

In addition to the three emplacement borings completed at CNTA, several other boreholes were completed for pre-shot and post-shot hydrologic testing and geologic exploration (Figure 2-2). Eight boreholes were completed to install downhole instruments for the Faultless event; eight borings were completed for hydrologic testing; and 15 boreholes were completed for geologic exploration. Three additional boreholes were completed for post-shot hydrologic and geologic testing. The depths of the test boreholes and wells ranged from about $94 \mathrm{~m}(307 \mathrm{ft})$ to $1,986 \mathrm{~m}$ $(6,515 \mathrm{ft})$ (Fenix and Scisson, 1973).

The Faultless nuclear device was detonated on January 19,1968 , at a depth of $975.4 \mathrm{~m}(3,200 \mathrm{ft})$ in emplacement boring UC-1 (DOE, 1994c). The shot affected both the volcanic unit at the working point and the overlying surficial alluvium. The detonation produced an asymmetric collapse graben bounded by several fractures and scarps evident in the surface ground zero (SGZ) area. Surface fractures range up to $2,700 \mathrm{~m}(9,000 \mathrm{ft})$ long. The surface expression of the graben is irregular in comparison to the typical shallow, cone-shaped or semicircular crater generally characteristic of subsurface detonations that alter the SGZ.

The SGZ area is now a subsided block bounded by fresh fault scarps that outline a nearly triangular area. Typical maximum vertical fracture displacements at SGZ are about $4 \mathrm{~m}$ (15 ft), and horizontal offsets are about $1 \mathrm{~m}(3 \mathrm{ft})$. Some of the displacement occurred at the time of detonation, with additional displacement related to post-shot subsidence. The total surficial area of subsidence is about $371.6 \mathrm{~m}^{2}\left(4,000 \mathrm{ft}^{2}\right)$. Seismic data from the test were approximately the same as predicted by the Environmental Research Corporation.(DRI, 1988). 

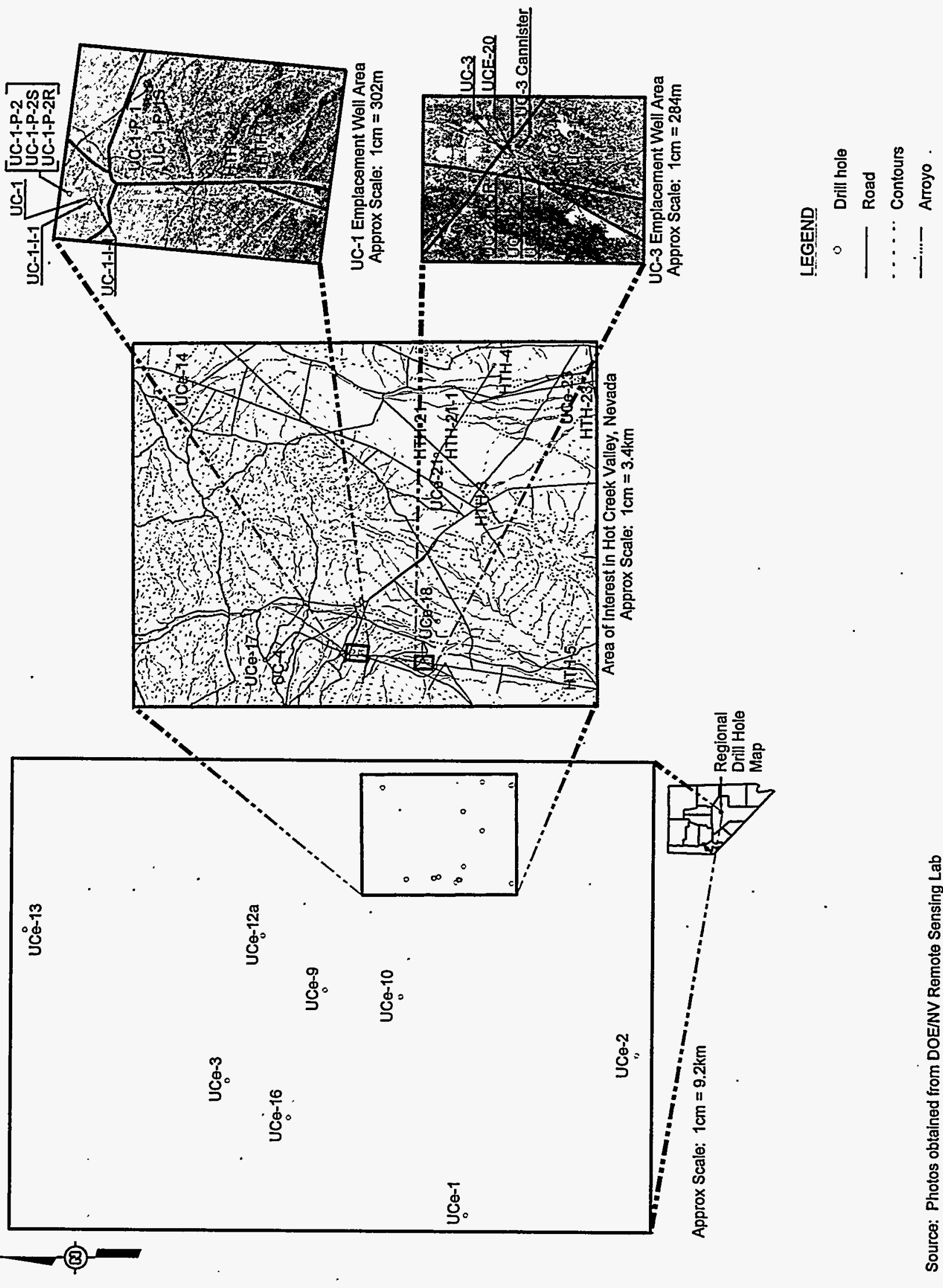

Figure 2-2

Boring and Well Locations

Central Nevada Test Area 
$\mid$ 
The CNTA site was decommissioned in 1973, and demobilization of the site commenced. All drilling sites, equipment, support facilities, and materials, including radiologically contaminated materials, were addressed in the site demobilization. In addition, areas "disturbed" by AEC operations were delineated. The DOE Nevada Operations Office retained control of some limited areas, while the BLM and the U.S. Air Force assumed responsibility of most of the area. Most borings and wells were abandoned, but five wells were left open for the CNTA Long-Term . Hydrologic Monitoring Program (LTHMP) (AEC, 1973, 1974).

The DOE, LLNL, and LASL completed several pre-shot and post-shot research projects at the CNTA, including post-shot radiological safety surveys. A radiological survey was completed by Eberline in 1973 prior to demobilization and restoration of the CNTA site. The survey detected only background radioactivity (Eberline, 1973). A second radiological and hazardous waste survey was completed by Reynolds Electrical \& Engineering Co., Inc. (REECo) in 1986 at several DOE facilities. Again, at CNTA, only background radiation was detected, but chromium (from a drilling mud additive) was detected in an uncovered drilling mud pit (REECo, 1986). Based on the two radiological surveys at CNTA, it appears the radionuclides from the Faultless event were contained within the shot cavity during the detonation, and post-shot drilling operations did not cause the release of any radionuclides.

\subsection{Corrective Action Sites}

The FFACO lists both surface (soil) and subsurface (groundwater) CASs at CNTA

(FFACO, 1996). The following surface CASs are listed:

- Central Mud Pit

- 14 additional mud pits at UC-1, UC-3 and UC-4

- Mud pit/borrow area at UC-1

- Two shaker pad areas

- Decontamination facility pit (Decon Facility Pit)

- Scrap and trash dump

- Four drilling mud/grout piles

- Two drill mud/grout spill areas

- Burn area .

- Three waste pile (drums, filters, etc.)

- Waste pile (metal, cable, etc.)

- Two protruding pipes 
The FFACO lists the following subsurface CASs:

- Faultless Event Shot Cavity (UC-1 Cavity)

- Emplacement Well UC-3

- Emplacement Well UC-4

Each of the surface and subsurface CASs is identified by a CAS number (Table 2-1). Three of the surface CASs listed in the FFACO and all of the subsurface CASs listed in the FFACO are not addressed in this CAIP. Each CAS not addressed in this CAIP is discussed in the following sections. All remaining surface CASs are discussed in Section 2.3 and will be investigated under this CAIP using the ESC methodology.

\subsubsection{Decontamination Facility Pit at UC-1}

A radiological decontamination (decon) facility pit (CAS 58-07-01) was constructed at UC-1 (AEC, 1974). The decon facility (Figure 2-3) was used to decontaminate downhole drilling equipment and other instruments potentially subjected to post-shot radioactivity. The 1973 Eberline survey (Section 2.1) did not detect any radioactivity within the pit (Eberline, 1973). The surrounding fence was then removed, and the pit was backfilled (AEC, 1974). The pit location west of the UC-1 Central Mud Pit is depicted in Figure 2-4. Because the 1973 Eberline survey did not detect any radiological contamination, the pit will not be addressed in the CNTA CAIP.

\subsubsection{Waste Piles}

An Environmental Restoration (ER) "housekeeping" site is defined as any disposed waste and/or any facility, location, or structure where waste was disposed of or contained. Designation as an ER housekeeping site, however, does not imply classification according to any regulatory framework. An ER housekeeping site may contain one or more waste types, including nonhazardous, recyclable, hazardous, radioactive, mixed, or unknown.

During the February 1996 site reconnaissance conducted by DOE and IT, four waste piles were identified at CNTA:

- Three sites near UC-3 (labeled CAS 58-98-01, CAS 58-98-02, and CAS 58-98-04)

- One site near the UC-1 Central Mud Pit (labeled CAS 58-98-03) 
Table 2-1

Corrective Action Sites

\begin{tabular}{|c|c|c|}
\hline $\begin{array}{c}\text { Corrective Action Site } \\
\text { Number }\end{array}$ & $\begin{array}{c}\text { Corrective Action Site } \\
\text { Description }\end{array}$ & General Location or Event \\
\hline \multicolumn{3}{|c|}{ Surface Sites (CAU No. 417) } \\
\hline $58-07-01$ & Decon Facility Pit & West of 58-09-01 \\
\hline $58-09-01$ & Central Mud Pit & East of UC-1 \\
\hline $58-09-02$ & Mud Pit & Southwest of 58-09-01 \\
\hline $58-09-03$ & Mud Pits (5) & $U C-4$ \\
\hline $58-09-04$ & Mud Pit/Borrow Area & UC-1 (HTH-1 Well) \\
\hline $58-09-05$ & Mud Pits (3) & UC-1 Surface GZ \\
\hline $58-09-06$ & Mud Pits (5) & UC-3 \\
\hline $58-10-01$ & Shaker Pad Area & Northeast of UC-3 \\
\hline $58-10-02$ & Shaker Pad Area & North of UC-4 \\
\hline $58-19-01$ & Scrap and Trash Dump & West of UC-3 RTP \\
\hline $58-35-01$ & Burn Area & West of 58-09-01 \\
\hline $58-44-01$ & Drilling Mud/Grout Piles (2) & West of 58-09-01 \\
\hline $58-44-02$ & Drilling Mud/Grout Piles (2) & West of 58-09-01 \\
\hline $58-44-03$ & Drill Mud/Grout Spill Area & Southeast of UC-3 \\
\hline $58-44-04$ & Drill Mud/Grout Spill Area & Southwest of UC-3 \\
\hline $58-98-01$ & Waste Pile (Drums, Filters, etc.) & West of UC-3 \\
\hline $58-98-02$ & Waste Pile (Drums, Filters, etc.) & South of UC-3 \\
\hline $58-98-03$ & Waste Pile (Drums, Filters, etc.) & Adjacent to 58-09-02 \\
\hline $58-98-04$ & Waste Pile (Metal, Cable, etc.) & Adjacent to $58-44-03$ \\
\hline $58-99-01$ & Protruding Pipes (2) & North of UC-3 \\
\hline \multicolumn{3}{|c|}{ Subsurface Sites (CAU No. 443) } \\
\hline $58-30-01$ & Emplacement Well UC-3 & UC-3 \\
\hline $58-30-02$ & Emplacement Well UC-4 & UC-4 \\
\hline $58-57-001$ & UC-1 Cavity & Faultless \\
\hline
\end{tabular}



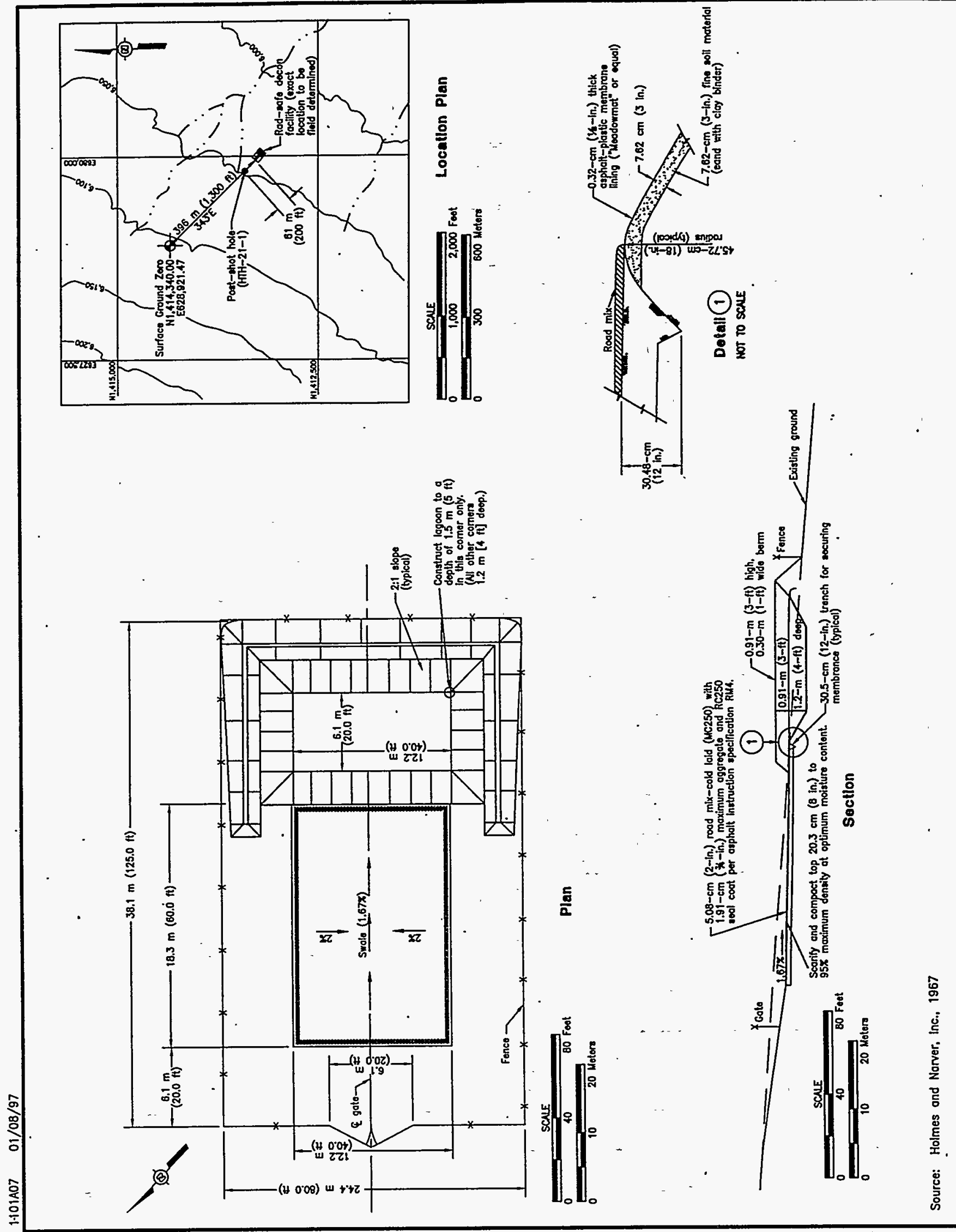

Figure 2-3

Decontamination Facility Pit at UC-1, Plan and Section, Central Nevada Test Area 


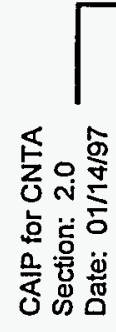

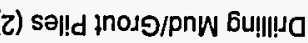

(द) sə!!d Inoגอ/pnw 6u!!|!ua

East unng

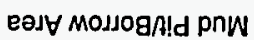

896L'Eo :ətep ojoud

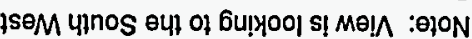

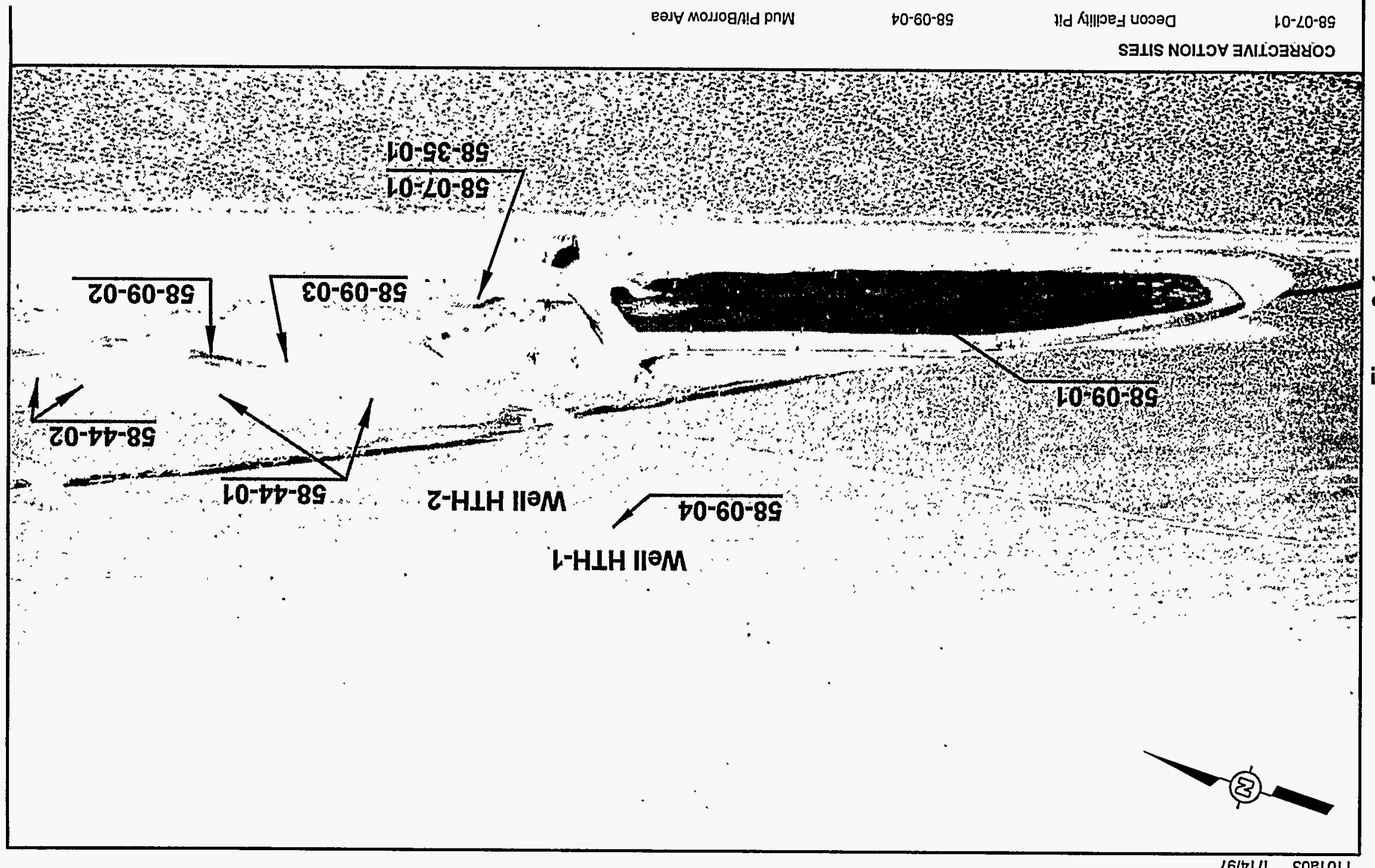



The waste piles are composed of metallic debris, heavy equipment air filters, crushed aerosol cans, and other general refuse. The sites range in size from $9 \mathrm{~m} \mathrm{x} 3 \mathrm{~m} \times 1.5 \mathrm{~m}$ $(30 \mathrm{ft} \times 10 \mathrm{ft} \times 5 \mathrm{ft})$ to $46 \mathrm{~m} \times 6 \mathrm{~m} \times 1 \mathrm{~m}(150 \mathrm{ft} \times 20 \mathrm{ft} \times 4 \mathrm{ft})$. As detailed in the FFACO, investigation of the two waste pile CASs at CNTA will be completed under the separate ER housekeeping sites program (FFACO, 1996).

\subsubsection{Subsurface CASs}

The subsurface CASs listed in the FFACO will be addressed in a separate CAIP.

\subsection{Potential Site Contamination}

The discussion of potential site contamination in this section has been compiled from the following information sources:

- The 1973 Eberline radiological survey (Eberline, 1973)

- The February 1996 DOE/IT site reconnaissance visit

- DOE/IT review of historical and recent aerial photographs of CNTA taken by the RSL (RSL, 1968; RSL, 1993)

\subsubsection{Potential Soil Contamination}

Each of the potential soil contamination CASs addressed in this investigation plan is detailed in the following text.

\subsubsection{Central Mud Pit}

The Central Mud Pit (CAS 58-09-01), located just southeast of UंC-1, was used to store drilling mud during the drilling of emplacement holes UC-3 and UC-4. During the February 1996 DOE/IT site reconnaissance, the pit was measured at approximately $168 \mathrm{~m} \times 131 \mathrm{~m}$ $(550 \mathrm{ft} \times 430 \mathrm{ft})$. Atomic Energy Commission documents indicate that the pit was not covered or diked (AEC, 1974), but 1993 aerial photographs show that the pit is fully bermed (Figure 2-4). No plans or engineering drawings of the pit could be obtained during the historical document review process.

\subsubsection{Additional Mud Pits at UC-1, UC-3, and UC-4}

\section{Additional Mud Pits at UC-1}

Four mud pits, smaller than the Central Mud Pit at UC-1, and one pit or borrow area were 
observed near UC-1 during the February 1996 site reconnaissance. These pits are designated by the following CAS identifications and labels:

- 58-09-02 (Pit 1A)

- 58-09-04 (Pit 1B)

- 58-09-05 (Pits 1C, 1D, 1E)

Mud Pit 1A is located about $183 \mathrm{~m}$ (600 ft) southwest of the Central Mud Pit at UC-1. The pit is a slight depression and measures approximately $9 \mathrm{~m} \mathrm{x} 8 \mathrm{~m} \mathrm{(29ft} \mathrm{x} 25 \mathrm{ft})$ and is bermed on the east side. Mud Pit 1B, possibly a borrow area and not a mud pit, was observed near UC-1 and adjacent to Well HTH-1. The feature measures $49 \mathrm{~m} \times 46 \mathrm{~m}$ (160 ft x $150 \mathrm{ft})$ and is bermed on the north, south, and west sides (Figure 2-4).

Mud Pit 1C (CAS 58-09-05) is located downslope from and to the east of UC-1, about halfway to the Central Mud Pit. Pit $1 \mathrm{C}$ is a slight, nearly semicircular depression which measures approximately $91 \mathrm{~m} \mathrm{x} 53 \mathrm{~m}$ ( $300 \mathrm{ft} \times 175 \mathrm{ft}$ ). A fresh scarp from the Faultless event divides the pit into two nearly equal areas (Figure 2-5). Sparse vegetation is growing within the pits.

Two additional areas which appear to be mud pits, labeled Pit 1D and Pit 1E, are evident near Pit $1 \mathrm{C}$ in historical aerial photographs (RSL, 1968). The pits measure about $183 \mathrm{~m}$ by $137 \mathrm{~m}$ ( $600 \mathrm{ft}$ by $450 \mathrm{ft}$ ) and $137 \mathrm{~m}$ by $91 \mathrm{~m}$ ( $450 \mathrm{ft}$ by $300 \mathrm{ft}$ ). Although backfilling was not fieldverified during the February $1996 \mathrm{DOE} / \mathrm{TT}$ site reconnaissance, the pits appear backfilled in recent aerial photographs (RSL, 1993). CAS 58-09-05 includes Pits $1 \mathrm{D}$ and 1E and Pit 1C discussed above.

\section{Mud Pits at UC-3 and UC-4}

The construction of mud pits at emplacement borings UC-3 and UC-4 was relatively welldocumented with engineering plans completed by Fenix and Scisson (1968). The plans for the UC-3 mud pits are included in Appendix B.

The plans indicate:

- Five mud pits at UC-3 (CAS 58-09-06), labeled Pits 3A through 3E

- Five mud pits at UC-4 (CAS 58-09-03), labeled Pits 4A through 4E 


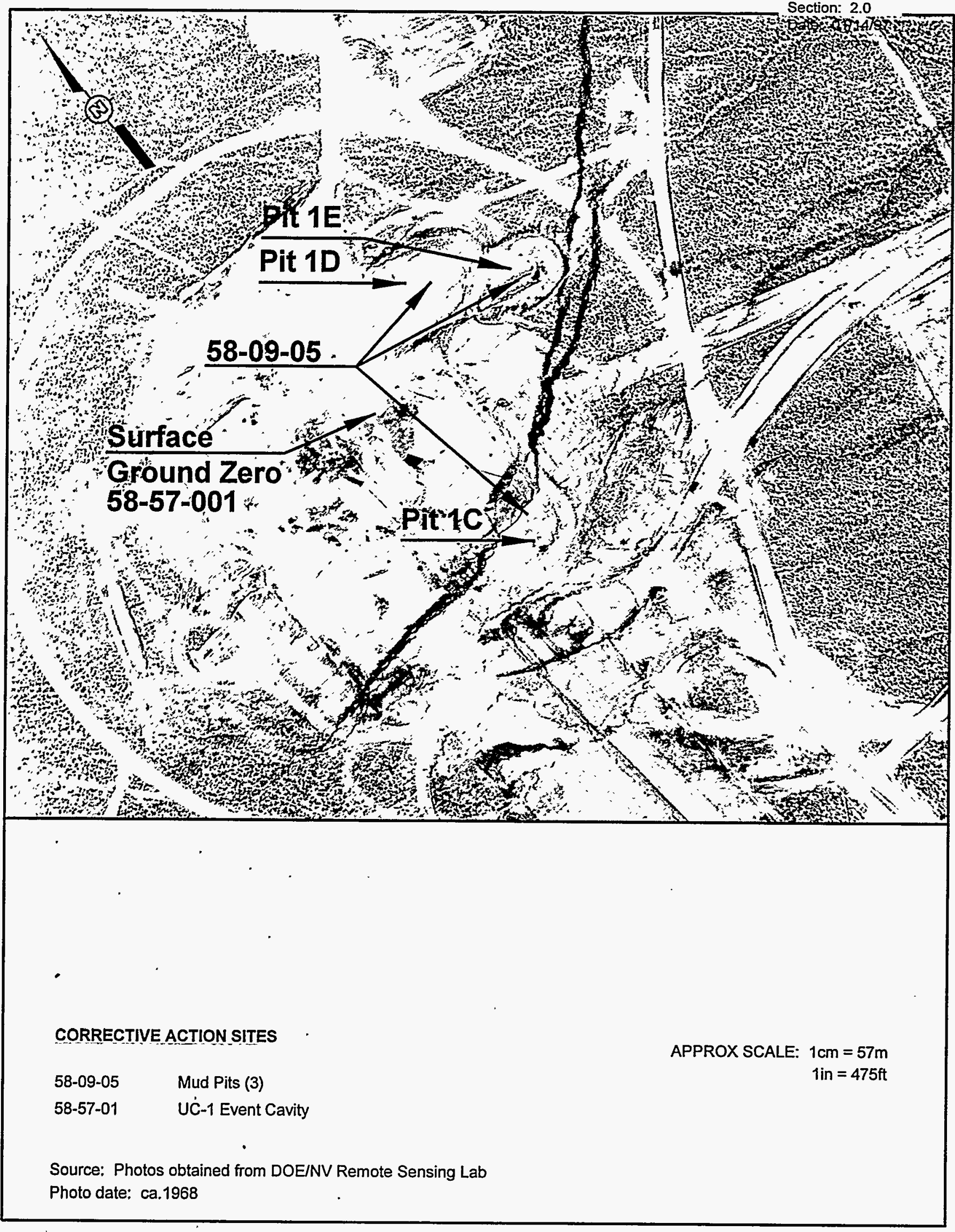

Figure 2-5

Mud Pits at UC-1

Centrál Nevada Test Area 


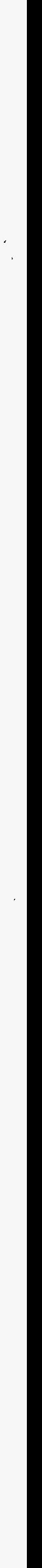


The mud pits at unused emplacement holes UC-3 and UC-4 (Figures 2-6, 2-7, and 2-8) were backfilled during the CNTA restoration activities in 1974 (AEC, 1974). The pits at UC-3 were apparently used for disposal of nonflammable scrap and nonsalvable items during site restoration activities in 1973 (AEC, 1973; AEC, 1974). All of the pits at UC-3 and four of the five pits at UC-4, however, were observed to be backfilled during the February 1996 site reconnaissance.

\subsubsection{Shaker Pad Areas}

Shaker pads are evident at unused emplacement borings UC-3 and UC-4 in historical aerial photographs (Figures 2-6, 2-7, and 2-8) (RSL, 1968). Shakers (shale shakers) are conveyor/vibration sorting machines installed on pads at mud rotary drilling sites to separate drill cuttings from drilling mud. The shakers force drill cuttings to accumulate in an outfall area while drilling mud is separated and pumped back to mud pits for storage and reuse. As drill cuttings accumulate, spilled mud is often spilled onto the ground or pooled around the shaker pad.

A substantial amount of pooled mud and water released from the UC-3 and UC-4 shaker pads is evident in the 1968 RSL aerial photographs. The spilled mud and water spread to the northeast of both pads. The shaker pad at UC-3 is labeled CAS 58-10-01, and the pad at UC-4 is labeled CAS 58-10-02.

\subsubsection{Burn Area}

An area possibly used for refuse burning is evident at the site near some degraded asphalt about $31 \mathrm{~m}$ (100 ft) west of the UC-1 Central Mud Pit. The Suspect Burn Area, labeled CAS 58-35-01, was observed during the February 1996 site reconnaissance. The location of this site corresponds with the.Decontamination Facility Pit evident in the 1968 RSL aerial photographs. The use of this site may be directly associated with the UC-1 Decontamination Facility Pit because the apparently burned material appears to be black plastic sheeting similar to lining which is evident in the $1968 \mathrm{RSL}$ aerial photographs of pit construction. Construction drawings of the pit (Figure 2-3) indicate that the pit was lined with an asphalt-plastic membrane. A large portion of the sheeting is buried and covered with vegetation. The exposed portion of the sheeting is $9 \mathrm{~m} \mathrm{x} 6 \mathrm{~m}$ ( $30 \mathrm{ft} \times 20 \mathrm{ft}$ ) and is black and blistered, with peeled and curling greencolored edges. Solar decomposition of the unburied plastic sheeting may contribute to its burned appearance. 



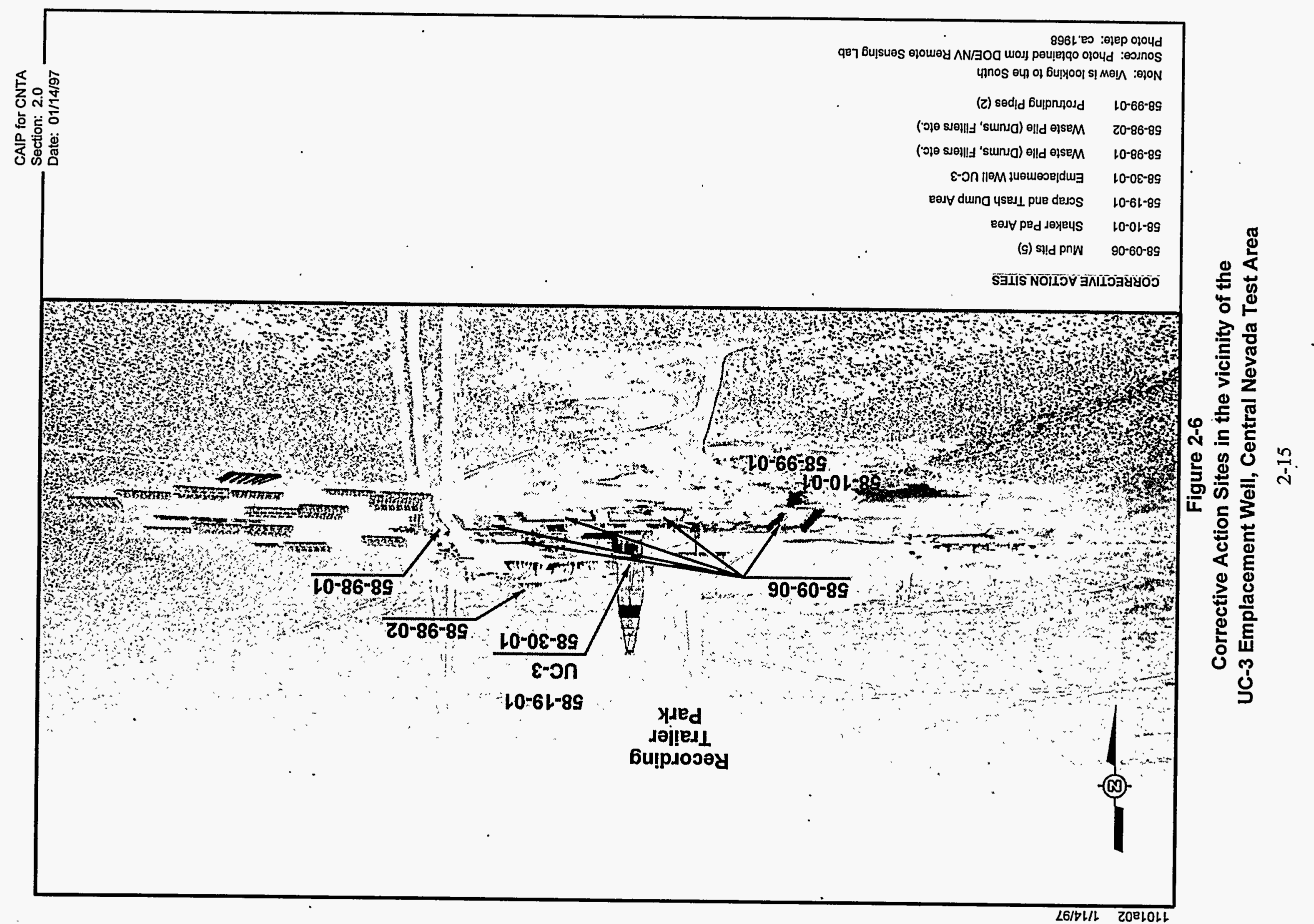






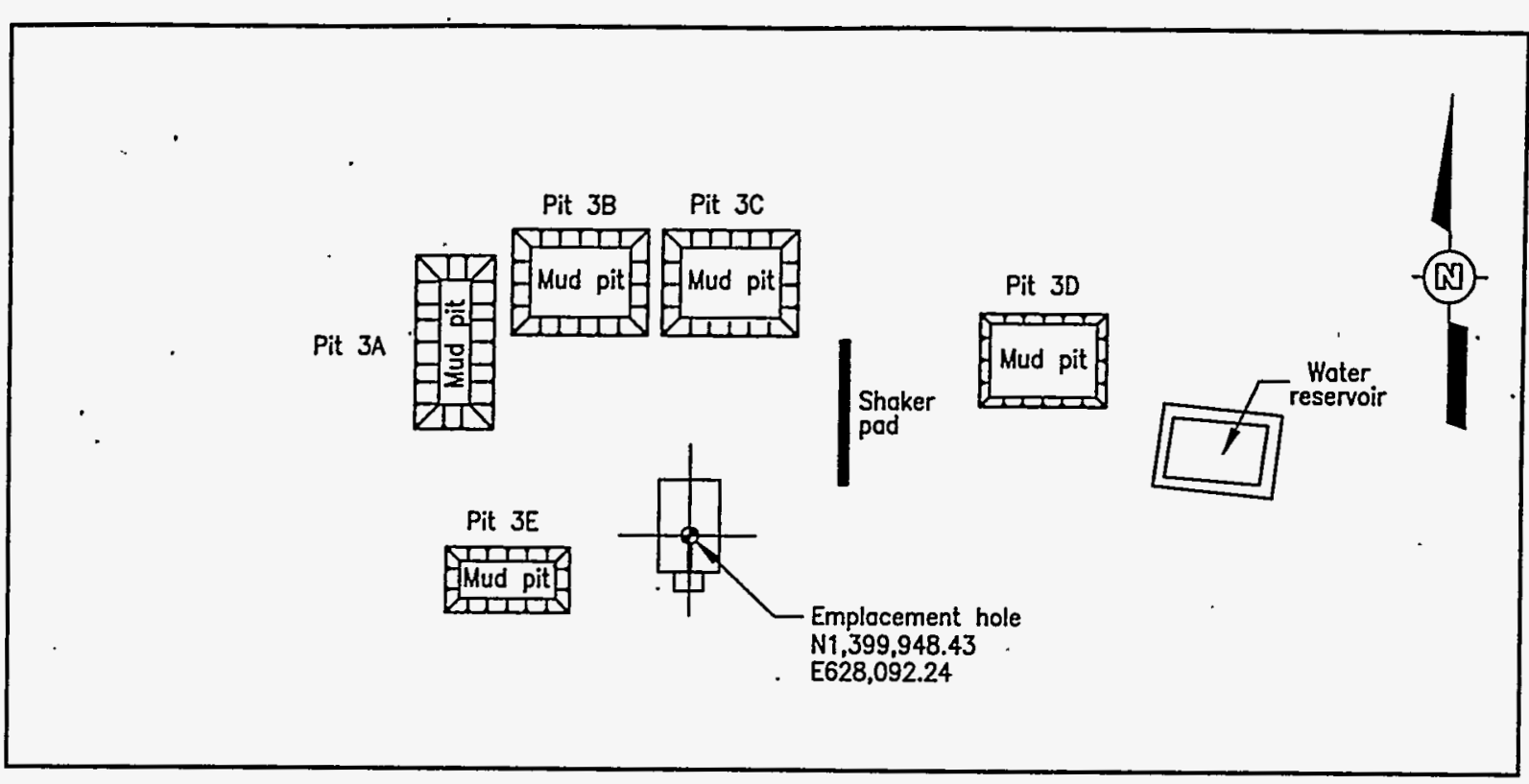

Drill Site -- UC-3

Pad elevation $=1,755 \mathrm{~m}(5,759 \mathrm{ft})$ $\begin{aligned} \text { Hole diameter }= & 137-\mathrm{cm}(54-\mathrm{in} .) \text { id with } 295-\mathrm{cm} \\ & \text { Hole depth }=1,448 \mathrm{~m}(4,750 \mathrm{ft})\end{aligned}$
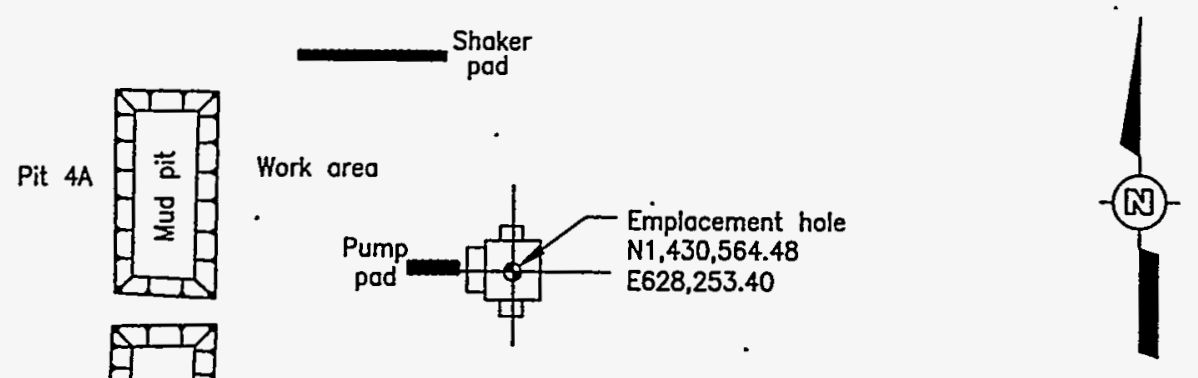

Pit $4 \mathrm{~B}$
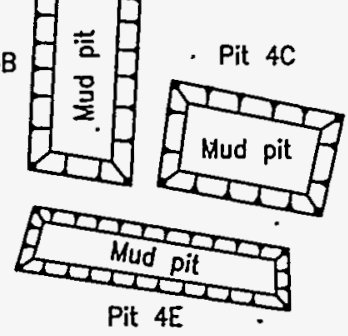

Pit 40

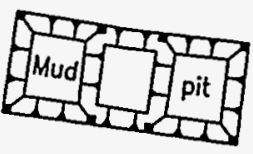

Drill Site $--\mathrm{UC}-4$

Pad elevation $=1,993.4 \mathrm{~m}(6,540 \mathrm{ft})$

Hole diameter $=137-\mathrm{cm}(54-\mathrm{in}$.$) id with 295-\mathrm{cm}(116-\mathrm{in}$.$) chomber$ Hole depth $=1,494 \mathrm{~m}(4,900 \mathrm{ft})$

SCALE

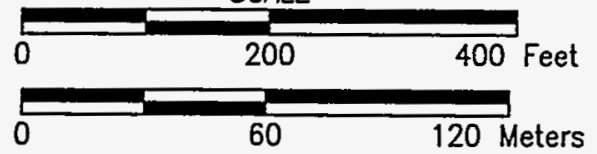

Source: Fenix \& Scisson, 1968 and AEC, 1973, and aerial photographs

Figure 2-8

UC-3 and UC-4 Mud Pits, Central Nevada Test Area $2-17$ 


\subsubsection{Scrap and Trash Dump}

A scrap and trash dump, labeled CAS 58-19-01, was located west of the Recording Trailer Park and south of UC-3 (Figure 2-6). This dump was used for disposal of nonflammable scrap and nonsalvable items during site restoration, and the dump was then backfilled (AEC, 1973; 1974). Because the dump was backfilled, its exact location could not be determined during the February 1996 site reconnaissance. .

\subsubsection{Drilling Mud/Grout Piles and Drill Mud/Grout Spill Area}

Four small drilling mud/grout piles consisting of a light gray material were observed just west of the UC-1 Central Mud Pit during the February 1996 site reconnaissance (Figure 2-9). Two pile areas are labeled CAS 58-44-01, and two areas are labeled CAS-58-44-02. The piles range in size from $2.4 \mathrm{~m}(8 \mathrm{ft})$ in diameter and $1 \mathrm{~m}(3 \mathrm{ft})$ high to $6 \mathrm{~m} \mathrm{x} 6 \mathrm{~m} \mathrm{x} 1 \dot{\mathrm{m}}(20 \mathrm{ft} \times 20 \mathrm{ft} \times 3 \mathrm{ft})$.

Two spill areas (labeled CAS 58-44-03 and CAS 58-44-04) just southeast and southwest of UC-3 are evident in the 1993 RSL aerial photographs (see Figure 2-9).

During the February 1996 site reconnaissance, the spill area to the southeast of UC-3 labeled CAS 58-44-03 was measured at about $283 \mathrm{~m} \mathrm{x} 55 \mathrm{~m}$ (930 ft x $180 \mathrm{ft}$ ). This elongated spill area contains small amounts of partially buried metal and debris. Vegetation in the area is sparse. The spill area to the southwest of UC-3 was not visited in February 1996.

\subsubsection{Protruding Pipes}

During the recent CNTA site reconnaissance, two unidentified steel pipes were observed near UC-3. The pipes are 5 centimeter (cm) $(2$ in.) and $10 \mathrm{~cm}$ (4 in.) in diameter and are located about $0.6 \mathrm{~m}(2 \mathrm{ft})$ apart. Uncapped and open to grade, the pipes extend about $0.5 \mathrm{~m}(1.5 \mathrm{ft})$ and $1 \mathrm{~m}(3 \mathrm{ft})$ below grade. Some liquid was evident inside the larger pipe. This site is labeled CAS 58-99-01.

\subsection{Investigative Background}

In addition to the 1973 radiological survey conducted by Eberline, two limited sampling and analysis events have been conducted at CNTA to evaluate potential chemical (non-radiological) contamination. The first was a hazardous waste installation assessment conducted by REECo in 1986 (REECo, 1986). The second was conducted by DOE and IT in 1995 (DOE, 1995). These two sampling and analysis events are discussed below. 
$6 I-\tau$

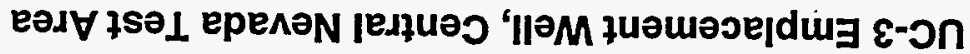

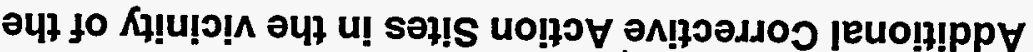

6-Z ə.มn6!ป

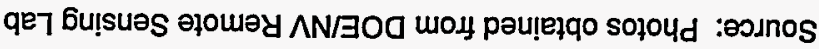

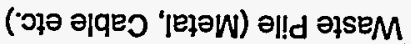

t0-86-89

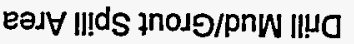

$\rightarrow 0-76-89$

$\forall 99 Z=U ! L$

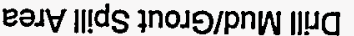

$\varepsilon 0-t \downarrow-89$

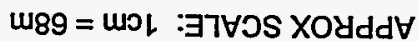

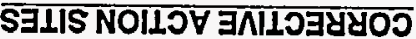

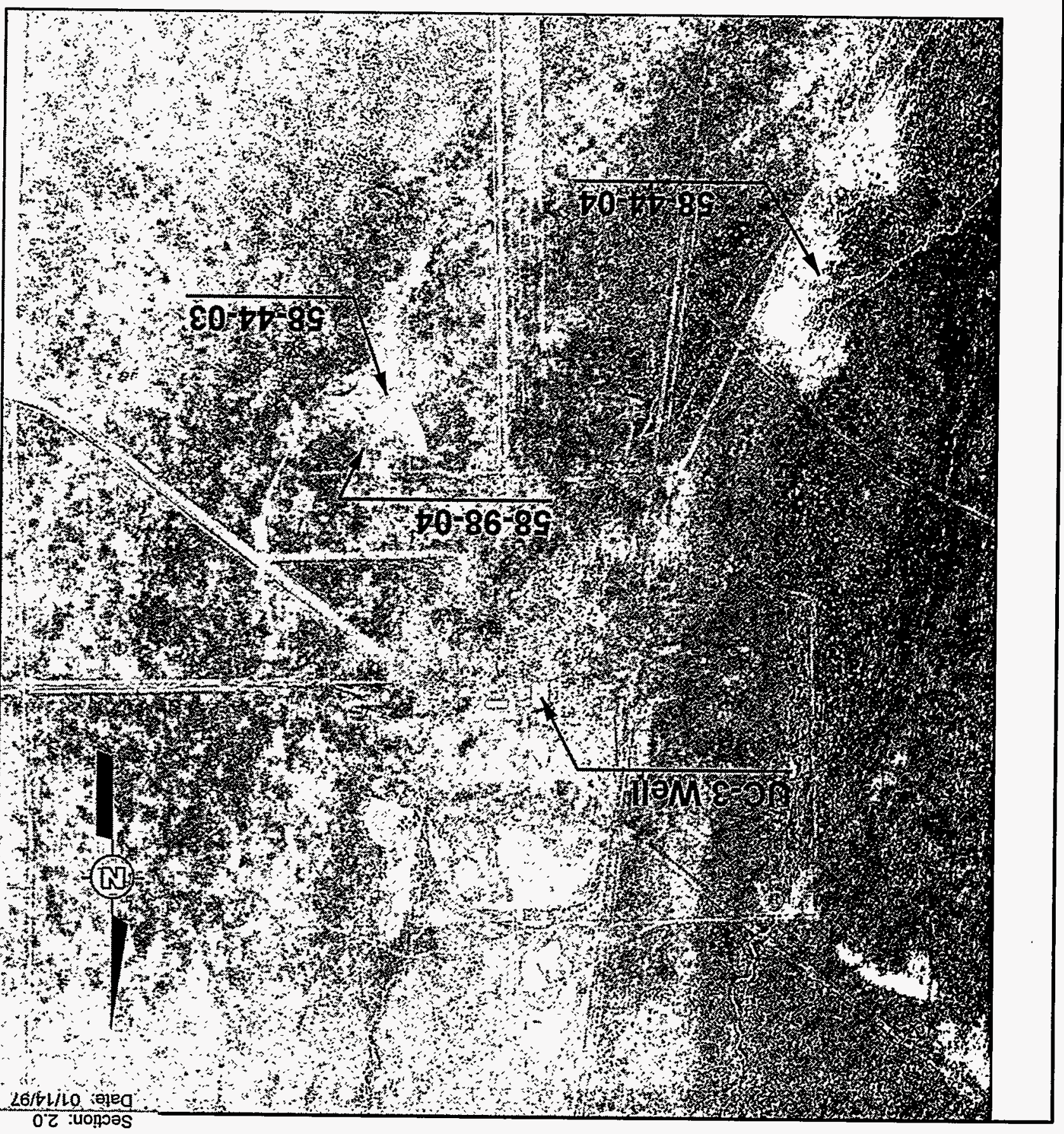

$\forall I N O$ dOJ dIVO 
During the 1986 REECo survey, the Central Mud Pit was found to be covered with a "dried oilylooking crust." Samples of the "oily dirt" and "oily crust" were collected from the mud pit and analyzed (REECo, 1986). The analytical data indicated the drilling fluids consisted of a bentonite drilling mud with diesel fuel and chrome lignosulfonate additives. The 1986 REECo data are listed in Table 2-2. The samples collected at the mud pit contained about 8 milligrams per liter (mg/L) of chromium as determined by the Extraction Procedure Toxicity (EP-TOX) . method. The chromium is likely from chrome lignosulfonate, a drilling mud thinner used to minimize drilling water loss (DRI, 1988). Because only two samples were collected in the 1986 REECo survey and both were collected at the edge of the pit, the extent of the chromium was not determined.

The 1995 DOE sampling and analysis event entailed sampling the Central Mud Pit, the uncovered mud pit at UC-4, and a drainage ditch in the vicinity of UC-1 (DOE, 1995). The samples were analyzed for total petroleum hydrocarbons (TPH) and Toxicity Characteristic Leaching Procedure (TCLP) extractable metals. The analytical results for the samples (Table 2-3) indicate that both the Central Mud Pit and the uncovered mud pit at UC-4 contain concentrations of TPH and TCLP chromium that exceed Resource Conservation and Recovery Act (RCRA) regulatory standards ( 40 CFR 261).

\section{$2.5 \quad$ Waste Inventory}

Based on available historical information and the analytical data from the 1986 REECo and 1995 DOE sampling events, the only waste materials suspected to be at CNTA are TPH and chromium associated with the mud pits, shaker pad areas, and drilling mud/grout piles. There currently is insufficient information available to estimate the quantity of waste present at the site.

\subsection{Release Information}

The only documented releases of contamination at the CNTA site are the spills associated with the UC-3 and UC-4 shaker pad areas. The berms at the Central Mud Pit and the uncovered mud pit at UC-4 were breached during the 1973 site restoration project to prevent water accumulation in the pits and to facilitate drying of the drilling mud (see Appendix B). Analytical results for samples collected in 1995 from a runoff ditch draining the Central Mud Pit suggest that drilling mud has not migrated from that pit; however, it currently is unknown whether any of the drilling mud has migrated from the UC-4 pit through the breach. 
Table 2-2

Analytical Data from the 1986 REECo Survey

\begin{tabular}{|c|c|c|c|c|c|c|}
\hline \multirow{2}{*}{$\begin{array}{l}\text { Sample } \\
\text { Location }\end{array}$} & \multirow{2}{*}{$\begin{array}{l}\text { Sample } \\
\text { Number }\end{array}$} & \multirow[b]{2}{*}{ Parameter } & \multicolumn{2}{|c|}{ EP Toxicity } & \multicolumn{2}{|c|}{ Halocarbon } \\
\hline & & & $\begin{array}{l}\text { Detected } \\
(\mathrm{mg} / \mathrm{L})^{\mathrm{a}}\end{array}$ & $\begin{array}{l}\text { Hazardous } \\
(\mathrm{mg} / \mathrm{L})\end{array}$ & $\begin{array}{l}\text { Detected. } \\
(\mu \mathrm{g} / \mathrm{kg})^{c}\end{array}$ & $\begin{array}{l}\text { Hazardous } \\
(\mathrm{kg})^{d}\end{array}$ \\
\hline Runoff Ditch & 1 & Lead & 0.3 & 5.0 & & \\
\hline \multirow{3}{*}{ Central Mud Pit } & 2 (oily crust) & Chromium & 7.9 & 5.0 & & \\
\hline & \multirow{2}{*}{2 (oily dirt) } & 2-Butanone & & & 37 & 1,000 \\
\hline & & Chromium & 8.1 & 5.0 & & \\
\hline
\end{tabular}

a Milligram(s) per liter

N Hazardous concentrations as listed in 40 CFR 261.24

Microgram(s) per kilogram

Hazardous quantity as listed in 40 CFR 261.33

$\mathrm{EP}=$ Extraction procedure

REECo = Reynolds Electrical \& Engineering Co., Inc.

Source: REECo, 1986 
Table 2-3

Central Mud Pit and UC-4 Mud Pit 1995 Analytical Results

(Page 1 of 2)

\begin{tabular}{|c|c|c|c|c|c|c|c|c|c|c|c|c|c|}
\hline \multirow{2}{*}{ Sample } & \multirow{3}{*}{$\begin{array}{l}\text { Reg } \\
\text { Std }^{1}\end{array}$} & \multicolumn{12}{|c|}{ Central Mud Pit } \\
\hline & & $1 \mathrm{~A}$ & $1 \mathrm{~B}$ & $2 A$ & 2B & $3 A$ & $3 B$ & $4 A$ & $4 B$ & $5 A$ & $5 B$ & $5 \mathrm{C}$ & 5D \\
\hline Depth (inches) & & $0-3$ & $18-21$ & $3-6$ & $20-23$ & $0-3$ & $20-23$ & $0-3$ & $20-23$ & $0-3$ & $.20-23$ & $66-72$ & $72-75$ \\
\hline $\mathrm{TPH}^{\mathrm{a}}(\mathrm{mg} / \mathrm{kg})^{\mathrm{b}}$ & 100 & 680 & 470 & 220 & 150 & 840 & 260 & 190 & 290 & 610 & 59 & $25 U$ & $25 U$ \\
\hline$\underset{\text { Arsenic }}{\operatorname{TCLP}(\mathrm{mg} / \mathrm{L})^{c}}$ & 5 & $0.23 \mathrm{U}$ & $0.23 \mathrm{U}$ & $0.23 \mathrm{U}$ & $0.23 \mathrm{U}$ & $0.23 \mathrm{U}$ & $0.23 \mathrm{U}$ & $0.23 U$ & $0.23 U$ & $0.23 \mathrm{U}$ & $0.23 \mathrm{U}$ & $0.23 \mathrm{U}$ & $0.23 U$ \\
\hline Barium & 100 & 2.1 & $0.80 \mathrm{~B}$ & 2.2 & 1.3 & 1.5 & $0.51 \mathrm{~B}$ & 0.99 & 0.94 & 1 & 1 & $0.69 \mathrm{~B}$ & $0.54 \mathrm{~B}$ \\
\hline Cadmium & 1 & $0.012 \mathrm{U}$ & $0.012 U$ & $0.012 \mathrm{U}$ & $0.012 \mathrm{U}$ & $0.012 \mathrm{U}$ & $0.012 U$ & $0.012 \mathrm{U}$ & $0.012 U$ & $0.012 U$ & $0.012 \mathrm{U}$ & $0.012 U$ & $0.012 U$ \\
\hline Chromium & 5 & 23 & 0.99 & 25.6 & 2.2 & 15.7 & 1.8 & 12.3 & 1.29 & 14.5 & 1.5 & $\cdot 0.93$ & 0.65 , \\
\hline Lead & 5 & $0.26 \mathrm{~B}$ & $0.16 U$ & $0.25 B$ & $0.16 \mathrm{U}$ & $0.21 \mathrm{~B}$ & $0.16 \mathrm{U}$ & $0.16 \mathrm{U}$ & $0.16 U$ & $0.16 \mathrm{U}$ & $0.16 U$ & $0.16 \mathrm{U}$ & $0.16 \mathrm{U}$ \\
\hline Mercury & 0.2 & 0.00046 & $0.00018 \mathrm{~B}$ & 0.00022 & 0.00023 & $0.00013 B$ & $0.0001 \mathrm{U}$ & $0.0001 \mathrm{U}$ & $0.00016 \mathrm{~B}$ & $0.00012 B$ & 0.00014 & $0.0001 \mathrm{U}$ & $0.0001 \mathrm{U}$ \\
\hline Selenium & 1 & $0.17 \mathrm{U}$ & $0.17 U$ & $0.17 \mathrm{U}$ & $0.17 \mathrm{U}$ & $0.17 \mathrm{U}$ & $0.17 U$ & $0.17 \mathrm{U}$ & $0.17 \mathrm{U}$ & $0.17 U$ & $0.17 U$ & $0.17 \mathrm{U}$ & $0.17 \mathrm{U}$ \\
\hline Silver & 5 & $0.013 B$ & $0.0088 \mathrm{~B}$ & $0.088 \mathrm{U}$ & $0.0088 \mathrm{~B}$ & $0.088 \mathrm{U}$ & $0.0088 \mathrm{U}$ & $0.0088 \mathrm{U}$ & $0.0088 \mathrm{U}$ & $0.00888 \mathrm{U}$ & $0.0088 \mathrm{U}$ & $0.0088 \mathrm{U}$ & $0.0088 \mathrm{U}$ \\
\hline
\end{tabular}

Refer to footnotes at the end of table. 
Table 2-3

Central Mud Pit and UC-4 Mud Pit 1995 Analytical Results (Page 2 of 2)

\begin{tabular}{|c|c|c|c|c|c|c|c|c|c|c|c|}
\hline \multirow{2}{*}{ Sample } & \multirow{3}{*}{$\begin{array}{l}\text { Reg } \\
\text { Std }\end{array}$} & \multicolumn{6}{|c|}{ UC-4 Mud Pit } & \multicolumn{4}{|c|}{ Runoff Ditch } \\
\hline & & $6 A$ & $6 B$ & 7A & 7B & $8 A$ & $8 B$ & $9 A$ & $10 A$ & $11 B$ & $12 A$ \\
\hline Depth (inches) & & -3 & $20-23$ & $0-3$ & $.20-23 v$ & 0.3 & $20-23$ & 0.3 & 0.3 & $0-3$ & $0-3$ \\
\hline $\mathrm{TPH}^{\mathrm{a}}(\mathrm{mg} / \mathrm{kg})^{\mathrm{b}}$ & 100 & 150 & $140^{\circ}$ & 96 & $25 U$ & 130 & $25 U$ & $25 \mathrm{U}$ & $25 U$ & $25 U$ & $25 U$ \\
\hline $\begin{array}{c}\mathrm{TCLP}(\mathrm{mg} / \mathrm{L})^{\mathrm{c}} \\
\text { Arsenic }\end{array}$ & 5 & $0.23 \mathrm{U}$ & $0.23 \mathrm{U}$ & $0.23 \mathrm{U}$ & $0.23 U$ & $0.23 \mathrm{U}$ & $0.23 U$ & $0.23 U$ & $0.23 \mathrm{U}$ & $0.23 \mathrm{U}$ & $0.23 \mathrm{U}$ \\
\hline Barium & 100 & $0.44 B$ & $0.49 \mathrm{~B}$ & $0.52 \mathrm{~B}$ & $0.21 \mathrm{~B}$ & $0.57 \mathrm{~B}$ & $0.17 \mathrm{~B}$ & 1.1 & 1.1 & $0.68 \mathrm{~B}$ & $0.57 \mathrm{~B}$ \\
\hline Cadmium & 1 & $0.012 U$ & $0.012 \mathrm{U}$ & $0.012 \mathrm{U}$ & $0.012 U$ & $0.012 U^{\prime}$ & $0.012 \mathrm{U}$ & $0.012 U$ & $0.012 U$ & $0.012 \mathrm{U}$ & $0.012 U$ \\
\hline Chromium & 5 & 6.6 & 0.96 & 6.8 & 0.53 & 10.7 & 10.8 & 0.1 & $0.035 \mathrm{~B}$ & $0.017 \mathrm{~B}$ & $0.011 U$ \\
\hline Lead & 5 & $0.16 \mathrm{~B}$ & $0.16 \mathrm{U}$ & $0.16 \mathrm{~B}$ & $0.16 \mathrm{U}$ & $0.16 \mathrm{~B}$ & $0.16 \mathrm{U}$ & $0.16 \mathrm{U}$ & $0.16 \mathrm{U}$ & $0.16 \mathrm{U}$ & $0.16 U$ \\
\hline Mercury & 0.2 & $0.0001 \mathrm{U}$ & 0.00014 & $0.0001 \mathrm{U}$ & $0.0001 \mathrm{U}$ & $0.0001 \mathrm{U}$ & $0.0001 \mathrm{U}$ & $.0 .0001 \mathrm{U}$ & $0.0001 \mathrm{U}$ & $0.0001 \mathrm{U}$ & $0.0001 \mathrm{U}$ \\
\hline Selenium & 1 & $0.17 U$ & $0.17 \mathrm{U}$ & $0.17 \mathrm{U}$ & $0.17 U$ & $0.17 \mathrm{U}$ & $0.17 \mathrm{U}$ & $0.17 \mathrm{U}$ & $0.17 \mathrm{U}$ & $0.17 \mathrm{U}$ & $0.17 U$ \\
\hline Silver & 5 & $0.0088 \mathrm{U}$ & $0.0088 U$ & $0.0088 \mathrm{U}$ & $0.0088 U$ & $0.0088 \mathrm{U}$ & $0.0088 \mathrm{U}$ & $0.0088 \mathrm{U}$ & $0.011 B$ & $0.0088 U$ & $0.0088 U$ \\
\hline
\end{tabular}

a Total petroleum hydrocarbon(s) .

Milligram(s) per kilogram

Miligram(s) per liter

${ }^{1}$ Regulatory Standard (Nevada State Environmental Commission, 1996; 40 CFR 261)

$U=$ Contaminant not detected at specified level.

$B=$ Reported value is above the instrument detection limit, but below the U.S. EPA Contract Laboratory Program Contract Required Detection Limil 


\subsection{Study Objectives}

As discussed in Section 1.0, this CAIP addresses the surface CAU at CNTA (CAU No. 417).

The objectives for the corrective action investigation were established by using the Data Quality Objective (DQO) process developed by the U.S. Environmental Protection Agency (EPA, 1993, 1994). The DQOs are qualitative and quantitative statements that specify the type, amount, and quality of the environmental data required to support corrective action decisions for the impoundment. The DQO process was employed to clearly define the purposes for which environmental data will be collected and used and to design a data collection program that will satisfy these purposes.

\subsection{Corrective Action Site Groups}

The corrective action investigation at CNTA will address $15 \mathrm{CASs}$ in the surface sites CAU. For the purpose of the CAIP and to simplify the DQO process, the surface CASs have been grouped according to the investigative approach to be used. The site groups developed for the CAIP are identified in the following sections.

\subsubsection{Mud Pits, Shaker Pad Areas and Drilling Mud/Grout Piles}

The mud pits, shaker pad areas, and drilling mud/grout piles present at the CNTA are all associated with emplacement hole and other well drilling activities. They are expected to have similar contaminants (drilling mud additives) and similar investigative approaches (sampling and laboratory analysis). The CASs included in this group are:

\section{Central Mud Pit Area:}

- Central Mud Pit (CMP) (CAS \# 58-09-01)

- Mud pit southwest of the CMP (CAS \# 58-09-02)

- Two drilling mud/grout piles southwest of the CMP (CAS \# 58-44-01)

- Two drilling mud/grout piles west of the CMP (CAS \# 58-44-02)

UC-1 Area:

- Mud pit/borrow area near UC-1 (HTH-1 Well) (CAS \# 58-09-04)

- Three mud pits near UC-1 (CAS \# 58-09-05) 
- Five mud pits at UC-3 (CAS \# 58-09-06)

- Shaker pad area northeast of UC-3 (CAS \# 58-10-01)

- Drilling mud/grout spill area southeast of UC-3 (CAS \# 58-44-03)

- Drilling mud/grout spill area southwest of UC-3 (CAS \# 58-44-04)

UC-4 Area:

- Five mud pits at UC-4 (CAS \# 58-09-03)

- Shaker pad area north of UC-4 (CAS \# 58-10-02)

\subsubsection{Miscellaneous Surface Sites}

Three additional surface CASs need to be located and/or investigated to determine their nature. Based on historical information (AEC, 1973; AEC, 1974), contamination is not expected to be associated with these CASs. The three CASs included in this group are:

- Scrap and trash dump west of UC-3 (CAS \# 58-19-01)

- Two protruding pipes north of UC-3 (CAS \# 58-99-01)

- Burn area adjacent to the decon facility pit (CAS \# 58-35-01)

\subsection{Site Conceptual Model}

Due to the number of CASs and diversity of site types included in the two surface sites CAS groups, individual site conceptual models have not been developed for each CAS. However, assumptions have been made for the various surface site CASs to formulate the basis for exposure pathways and contaminant migration and to assist in the development of objectives for the corrective action investigation.

The assumptions made for the mud pits are:

- All mud pits except for the Central Mud Pit and one mud pit at UC-4 are covered with soil. All of the mud pits are bermed; however, the berms of the Central.Mud Pit and the one uncovered mud pit at UC-4 were breached during the 1973 site restoration operation to prevent water accumulation and facilitate drying of the mud.

- With the exception of the Central Mud Pit and the uncovered mud pit at UC-4, the quantity of drilling mud in the mud pits is unknown. The planning directive for the 1973/1974 site restoration project indicates that little or no mud was present in the mud pits before restoration activities were initiated (AEC, 1973). However, if mud is present 
in any of the covered mud pits, it should be readily apparent in samples collected from the pits because of its clayey texture and dark gray to black color and should be readily detectable by electrical geophysical measurements.

- The drilling mud in the uncovered mud pit at UC-4 is approximately four feet thick. Because of the similarities between this pit and the other pits at UC- 4 and UC-3, a maximum of four feet of mud is expected in the covered pits.

- During the site demobilization and restoration activities conducted and documented by the AEC in 1973 and 1974, some or all of the mud pits at UC-3 were used for disposal of nonflammable scrap materials and nonsalvable items prior to being covered with soil (Appendix B).

- Based on historical documentation and process knowledge, the drilling mud present in all of the mud pits at each location should be similar in composition (i.e., the analytical results for one mud pit at a location should be representative of all mud pits at that location). The drilling mud specifications for UC-3 and UC-4 are included in Appendix B.

- Because drilling mud was discharged to the mud pits in a mostly aqueous form, diesel fuel, mixed with the mud during drilling operations, is expected to have "floated" to the top of the mud after drilling operations stopped. Because of this, the diesel fuel is expected to be concentrated near the top of the mud.

- Groundwater is approximately $168 \mathrm{~m}(550 \mathrm{ft})$ below the ground surface.

- There has been little or no migration of contaminants from the mud pits into underlying soils due primarily to the contaminant adsorption capacity of bentonite and the lack of - precipitation to act as a driver for contaminant migration. In addition, the bermed mud pits at UC-3 and UC-4 were lined with bentonite before mud was introduced, which would further inhibit migration into the underlying soils.

- The primary potential exposure route is by ingestion and/or inhalation of contaminated soil resulting from intrusion into the mud pits.

The assumptions made for the shaker pad areas are:

- The drilling mud spilled from the UC-3 and UC-4 shaker pads was covered with clean soil during the 1973/1974 site restoration project (AEC, 1974). It is assumed that the cover soil is no more than three feet thick.

- It is unknown how much mud was spilled from the shaker pads, how thick the spilled mud may be, or how thick the soil cover is. However, if a layer (or layers) of mud is 
present in the soils, it should be readily apparent in samples collected from the areas of the spills because of its color (dark gray to black) and should be readily detectable by electrical geophysical measurements.

- There has been little or no migration of contaminants from the mud spills into underlying soils due primarily to the contaminant adsorption capacity of bentonite and the lack of precipitation to act as a driver for contaminant migration.

The assumptions made for the drilling mud/grout piles are:

- It is unknown whether the drilling mud/grout piles are composed of drilling mud, cement grout, or both. However, the light gray color of the material suggests that it is likely to be cement grout, since drilling mud in both the Central Mud Pit and the one uncovered mud pit at UC-4 is dark gray to black.

The assumptions made for the miscellaneous CAS group are:

- The scrap and trash dump was a trench that was used for disposal of nonflammable debris and nonsalvable items (all nonhazardous) during the 1973/1974 site restoration project (AEC, 1973, 1974) (Appendix B). The trench was covered with clean soil during the restoration project, and its exact location currently is unknown. All material disposed of in the dump is expected to be confined to the trench.

- The two protruding pipes north of UC-3 may be associated with some type of an underground structure, such as an underground storage tank (UST) that is currently filled with sand or soil.

- The decontamination facility pit was lined with an asphalt-plastic membrane (Figure 2-3). It is expected that the material observed in the burned area is actually weathered liner material from the decontamination pit, as the location of the material corresponds with the location of the decontamination facility pit (see Section 2.2.1).

\subsection{Contaminants of Potential Concern}

\subsubsection{Mud Pits, Shaker Pad Areas, and Drilling Mud/Grout Piles}

The contaminants of potential concern (COPCs) for the mud pits, shaker pad areas, and drilling mud/grout piles are constituents of drilling mud additives that were used at the site. Based on historical records (Appendix B) and field data, the COPCs are:

- Total petroleum hydrocarbons (TPH), as diesel

- Chromium (from chrome lignosulfonate and/or chrome lignite) 
Chrome lignosulfonate and chrome lignite were included in the drilling mud specifications for UC-3 and UC-4 (Appendix B). Samples collected from the Central Mud Pit and the uncovered mud pit at the vicinity of UC-4 by DOE/NV and IT personnel in 1995 contained TPH as diesel and waste oil and also contained levels of chromium that exceeded the RCRA (40 CFR 261.35) toxicity characteristic limit $(5 \mathrm{mg} / \mathrm{L})$ in Toxicity Characteristic Leaching Procedure extracts from the samples (Table 2-3). There are no historical records of RCRA hazardous wastes on site. Previous sampling events have shown no evidence for the presence of any other COPCs at the site.

In addition to the above COPCs, man-made radionuclides are COPCs for UC-1 mud pit $1 \mathrm{D}$ (Figure 2-4) because this mud pit may have been used to store waste drilling mud generated during the drillback operation into the UC-1 shot cavity.

\subsubsection{Miscellaneous Surface Sites}

Based on the assumptions described in Section 3.2, no COPCs have been identified for the three CASs in this group.

\subsection{DQO Process}

The DQO process is a systematic planning tool for establishing criteria for data type, quantity, and quality and for developing data collection programs that satisfy the needs of the project. It is an iterative, seven-step process, and these seven steps are:

- State the problem.

- Identify the decision.

- Identify the inputs to the decision.

- Define the study boundaries.

- Develop decision rules.

- Specify limits on the decision errors.

- Optimize the design for obtaining data.

These seven steps have been applied to the CNTA CAS groups, and they support a course of action for investigating the CNTA surface CAU.

The problem areas as discussed in the following DQO steps are based on grouping by CAS (i.e., mud pit, shaker pad, or drilling mud/grout piles). The on-site decision-making required by the ESC process suggests the following field analytical schedule. The sampling crews will be 
mobilized to each of the UC sites sequentially, not only to minimize travel time, but to also provide for all decision-makers to be involved in each type of CAS at one site. This will allow scrutiny of all sampling and analysis procedures and strategies at the first site, and modifications can be incorporated before moving to the second UC site. As a result; the three UC sites and the central mud pit can be considered as four nearly separate investigations during one field mobilization.

\subsubsection{Statement of the Problem}

\subsubsection{Mud Pits, Shaker Pad Areas, and Drilling Mud/Grout Piles}

The primary problem with the CASs included in this group is that the mud pits, shaker pad areas, and drilling mud/grout piles may contain contaminants that pose a threat to human health and the environment. The presence of these contaminants in most of the areas has not been determined, and, where present, their extent is unknown. Sections $2.3,2.5$, and 3.4.1 of this CAIP provide more detailed information regarding potential contamination at these CASs.

\subsubsection{Miscellaneous Surface Sites}

The primary problems with the three CASs included in this group are that the location and areal dimensions of the scrap and trash dump are currently unknown; the purpose of the two protruding pipes north of UC-3 is unknown; and the composition of the material in the burned area is unknown.

\subsubsection{Identification of the Decision}

\subsubsection{Mud Pits, Shaker Pad Areas, and Drilling Mud/Grout Piles}

Implementation of the mud pits, shaker pad areas, and drilling mud/grout piles investigation portion of this CAIP is intended to support the following decisions:

- Determine whether the soils and drilling mud present in the mud pits, shaker pad areas, and drilling mud/grout piles are contaminated above preliminary action levels. The contaminants of potential concern for these areas are discussed in Section 3.4.1, and preliminary action levels are discussed in Section 3.4.3.3.

- Determine whether contaminated drilling mud has migrated from the breaches in the Central Mud Pit and uncovered UC-4 mud pit berms. 


\subsubsection{Miscellaneous Surface Sites}

Implementation of the miscellaneous surface sites portion of this CAIP is intended to support the following decisions:

- Determine the location and areal extent of the scrap and trash dump west of UC-3.

- Determine whether the two protruding pipes north of UC-3 are associated with an underground structure and, if so, determine what that structure is.

'. Determine whether the material at the suspected burn area adjacent to the decontamination facility pit is weathered liner from the pit.

\subsubsection{Identification of Inputs to the Decision}

\subsubsection{Mud Pits, Shaker Pad Areas, and Drilling Mud/Grout Piles}

The potential contamination of the soils and drilling mud present in the mud pits, shaker pad areas, and drilling mud/grout piles will be evaluated by collecting and analyzing samples from these areas. Potential contaminant migration from the Central Mud Pit and the uncovered mud pit at UC-4 will be evaluated by collecting and analyzing samples from outside of those mud pits in the vicinity of the breaches in the mud pit berms. Appendix $C$ and Section 4.0 of this CAIP provide a detailed description of the sampling and analysis program for the mud pits, shaker pad areas, and drilling mud/grout piles.

Although historical information is available for the site, it is not sufficient to confirm that any wastes disposed of in the mud pits or shaker pad areas would be considered RCRA listed wastes. Because of this, it is assumed that if the mud pit, shaker pad area, and drilling mud/grout piles soils and/or drilling mud are removed as a part of site remediation, they would be characteristic wastes. The sampling and analysis program for the mud pits, shaker pad areas, and drilling mud/grout piles described in Appendix $\mathrm{C}$ includes collection samples of soils or drilling mud for TCLP volatile and semivolatile organic compounds and TCLP metals analyses from areas that exceed TPH and/or hexavalent chromium preliminary action levels to allow evaluation of remedial alternatives and to support waste management decisions.

\subsubsection{Miscellaneous Surface Sites}

The scrap and trash dump west of UC-3 and the two protruding pipes north of UC-3 will be evaluated by using surface geophysical surveys, as described in Section 4.1. If the two 
protruding pipes are associated with an underground storage tank, samples will be collected from inside of the tank to determine if it contained petroleum products and from the soils adjacent to the tank to determine if it had leaked. The suspected burn area adjacent to the decontamination facility pit will be evaluated by visual inspection to determine if the material that appears to be burned is degraded liner from the pit.

\subsubsection{Preliminary Action Levels}

As discussed in Section 3.4.1, the primary COPCs for the CNTA mud pits, shaker pad areas, and drilling $\mathrm{mud} /$ grout piles are TPH and chromium. In addition, man-made radionuclides are COPCs for one of the mud pits located at UC-1 (pit 1D on Figure 2-5), even though they were not detected in previous investigations. In order to develop decision rules using the DQO process (Section 3.4.5, below), it is necessary to first develop preliminary action levels. For the purpose of this CAIP, the preliminary action levels are based on the corrective action regulation adopted by the Nevada State Environmental Commission on September 10, 1996 (Nevada State Environmental Commission, 1996). These preliminary action levels for the targeted analytes are:

- $\underline{\text { TPH }}$ - 100 milligrams per kilogram $(\mathrm{mg} / \mathrm{kg}$ ), which is the NDEP regulatory action level for TPH set forth in the corrective action regulation (Nevada State Environmental Commission, 1996).

- Chromium (total) - $390 \mathrm{mg} / \mathrm{kg}$, which is the generic soil screening level (SSL) for hexavalent chromium published in the EPA guidance document entitled Soil Screening Guidance: Technical Background Document (EPA, 1996a). This SSL also applies to total chromium concentrations when the portion of the total concentration that is hexavalent chromium is unknown. Although hexavalent chromium is not expected to be present in the mud pits or shaker pad areas, its SSL is more conservative than the SSL for trivalent chromium $(78,000 \mathrm{mg} / \mathrm{kg})$, so it is being used to establish the chromium measurement objective for the project. As described in Appendix B, if the total chromium concentration in a sample exceeds the preliminary action level, then the percentage that is hexavalent chromium will be determined.

The chromium SSL developed by EPA was selected as the preliminary action level in accordance with the Nevada corrective action regulation for sites where ingestion, dermal contact, and/or inhalation are the primary exposure pathways (Nevada State Environmental Commission, 1996).

- Man-made radionuclides - analytical laboratory reporting limits 
It should be noted that the preliminary action levels identified for this CAIP are not necessarily the cleanup goals for the CASs, but are primarily intended to provide the basis for decisions and decision rules and to ensure that the analytical methods selected for the project are capable of measuring the contaminants of potential concern at or below levels of concern.

\subsubsection{Measurement Objectives}

The analytical measurement objectives for the mud pit, shaker pad area, and drilling mud/grout pile samples have been established at 50 percent of the preliminary action level values (except for radionuclides) to ensure that the analytical methods selected for the project are capable of meeting quantitation limit needs for the project. Table 3-1 provides a list of the analytical methods to be used, the measurement objectives for the targeted analytes, and the field and laboratory analytical reporting limits for the targeted analytes that typically are achieved for similar matrices. As indicated in the table, the analytical methods specified for nonradiolotical analyses for the project are capable of measuring the targeted analytes at levels significantly below the measurement objectives.

Table 3-1 also lists the analytical accuracy and precision goals established for the project.

\subsubsection{Definition of the Study Area.}

\subsubsection{Mud Pits, Shaker Pad Areas, and Drilling Mud/Grout Piles}

Each mud pit, shaker pad area, and drilling mud/grout pile will be an individual study area. The physical boundaries of the mud pits study areas are:

- Within the bermed area of each mud pit

- Outside of and downslope from breached berms, as determined by historical aerial photography (RSL, 1968), visual observations of breached berms, and surface geophysical data indicating enhanced soil electrical conductivity

- Six meters $(20 \mathrm{ft})$ below the bottom of each mud pit or $0.6 \mathrm{~m}(2 \mathrm{ft})$ below the deepest sample that exceeds action levels, whichever is shallower 
Table 3-1

CNTA Mud Pits, Shaker Pad Areas, and Drilling Mud/Grout Piles
Investigation Measurement Objectives

\begin{tabular}{|c|c|c|c|c|c|}
\hline Analyte & Method & $\begin{array}{c}\text { Measurement } \\
\text { Goal }\end{array}$ & $\begin{array}{c}\text { Analytical } \\
\text { Reporting } \\
\text { Limit }\end{array}$ & $\begin{array}{l}\text { Precision } \\
\text { (RPD) }\end{array}$ & $\begin{array}{c}\text { Accuracy } \\
(\% R)\end{array}$ \\
\hline TPH (diesel) & $\begin{array}{c}3545 / 8015^{a} \\
\text { Modified }\end{array}$ & $50 \mathrm{mg} / \mathrm{kg}$ & $25 \mathrm{mg} / \mathrm{kg}$ & \pm 40 & . 61 to 144 \\
\hline Total Chromium & $\mathrm{XRF}$ & $195 \mathrm{mg} / \mathrm{kg}$ & $60 \mathrm{mg} / \mathrm{kg}$ & NS & NS \\
\hline Total Chromium & $3051 / 7190^{b}$ & $195 \mathrm{mg} / \mathrm{kg}$ & $10 \mathrm{mg} / \mathrm{kg}$ & \pm 35 & 75 to 125 \\
\hline $\begin{array}{l}\text { Hexavalent } \\
\text { Chromium }\end{array}$ & $3060 \mathrm{~A} / 7196 \mathrm{~A}^{\mathrm{b}}$ & $195 \mathrm{mg} / \mathrm{kg}$ & $130 \mathrm{mg} / \mathrm{kg}$ & \pm 35 & 75 to 125 \\
\hline Gross Alpha & $S M 7110^{C}$ & $1 \mathrm{pCi} / \mathrm{g}$ & $1 \mathrm{pCi} / \mathrm{g}$ & \pm 25 & 75 to 125 \\
\hline Gross Beta & $\operatorname{SM} 7110^{c}$ & $3 \mathrm{pCi} / \mathrm{g}$ & $3 \mathrm{pCi} / \mathrm{g}$ & \pm 25 & 75 to 125 \\
\hline Gamma-spec & $\begin{array}{c}\text { HASL } 300 \\
4.5 .2 .3^{\mathrm{d}}\end{array}$ & $1 \mathrm{pCi} / \mathrm{g}$ & $1 \mathrm{pCi} / \mathrm{g}$ & \pm 25 & 75 to 125 \\
\hline Tritium & EERF $\mathrm{H}-01^{\mathrm{e}}$ & $1 \mathrm{pCi} / \mathrm{g}$ & $1 \mathrm{pCi} / \mathrm{g}$ & \pm 25 & 75 to 125 \\
\hline
\end{tabular}

${ }^{a}$ EPA SW-846, Test Methods for Evaluating Solid Waste, $3^{\mathrm{d}}$ Edition, modified according to the California State Water Resources Control Board, Leaking Underground Fuel Tank Field Manual, Guidelines for Site Assessment, Cleanup, and Underground Storage Tank Closure, Appendix B (EPA, 1996b)

bEPA, SW-846, Test Methods for Evaluating Solid Waste, $3^{j}$ Edition (EPA, 1996b)

American Public Health Association, Standard Methods for the Examination of Water and Wastewater (APHA, 1992)

U.S. Department of Energy Environmental Measurements Laboratory Procedure Manual, HASL-300 (DOE, 1992a)

U.S. Environmental Protection Agency (EPA) Eastern Environmental Radiation Facility (EPA, 1984)

$\mathrm{pCi} / \mathrm{g}=$. PicoCurie(s) per gram .

$\mathrm{mg} / \mathrm{kg}=$ Milligram(s) per kilogram

$\mathrm{RPD}=$ Relative percent difference

$\% R=$ Percent recovery

NS $=$ Not specified

The physical boundaries of the shaker pad study areas are:

- The horizontal extent of the apparent drilling mud spills as determined by historical aerial photography (RSL, 1968), visual observations, and surface geophysical data indicating enhanced soil electrical conductivity

- A depth of $6 \mathrm{~m}(20 \mathrm{ft})$ below the ground surface or $0.6 \mathrm{~m}(2 \mathrm{ft})$ below the deepest sample that exceeds action levels, whichever is shallower The physical boundaries of the drilling mud/grout piles study areas are the horizontal and vertical extent of each pile. 
These boundaries are based on the preliminary site conceptual models discussed in Section 3.2 of the CAIP. The physical boundaries of the mud pits, shaker pad areas, and drilling mud/grout piles study areas may change depending on the results of the analytical data generated during sampling. There are no temporal constraints or boundaries for collection and use of data for the mud pits, shaker pad areas, and drilling mud/grout piles study areas.

\subsubsection{Miscellaneous Surface Sites}

Each of the three CASs in this group will be an individual study area. The physical boundaries of the scrap and trash dump study area are:

- The horizontal extent of apparently disturbed ground in the area where the dump is thought to be located

- The depth to which the surface geophysical instruments used for the investigation are effective

The physical boundaries of the two protruding pipes study area are:

- A horizontal area within a five meter radius of the pipes

- The depth to which the surface geophysical instruments used for the investigation are effective

The physical boundaries of the suspected burn area study area are the horizontal extent of the apparently burned material. No vertical boundaries have been established for the suspected burn area because the investigation of that area will consist of only visual inspection of the material that appears to be burned to confirm that it is part of the decontamination facility pit liner.

These boundaries are based on the preliminary site conceptual models discussed in Section 3.2 of the CAIP. The physical boundaries of miscellaneous surface sites study areas may change depending on the results of the investigations. There are no temporal constraints or boundaries for collection and use of data for the miscellaneous surface sites study areas. 


\subsubsection{Development of Decision Rules}

\subsubsection{Mud Pits, Shaker Pad Areas, and Drilling Mud/Grout Piles}

The analytical results for the samples collected from the mud pits, shaker pad areas, and drilling mud/grout piles will be used to determine if the mud pits and/or shaker pad areas require remediation. Since the character of the mud pits, shaker pads, and mud/grout piles differ fundamentally, the decision rules for each will vary.

\subsection{Mud Pits}

The mud pits contain two subsites (within the berms and outside of breached berms) which involve different decision rules. Evidence of a berm breach would include, but is not limited to, visual observations of the presence of bentonite or petroleum staining and geophysical data suggesting high clay content in soil outside of the berm.

For the mud pits subsites within berms, if the upper 90 percent confidence levels of the mean concentrations of all contaminants of potential concern are below preliminary action levels (see Section 3.5.3.4 for a discussion of preliminary action levels), then no further action will be required. If the upper 90 percent confidence level of the mean concentration of any contaminant of potential concern equals or exceeds its preliminary action level, then a limited number of remedial alternatives will be evaluated, such as no action, restricted site access, removal and off-site disposal, and in situ containment and capping. An appropriate remedial alternative will be selected based on the type(s) and concentration(s) of contaminants encountered. Appendix C provides a detailed discussion of the statistical sampling program designed to support application of this decision rule, and Figure 3-1 presents a flow chart for mud pit sampling based on the statistical design.

For the mud pits subsites outside of breached berms, if the concentration of any contaminant of potential concern equals or exceeds its preliminary action level, additional samples will be collected to determine the horizontal and vertical extent of the contamination outside of the berm. Once these boundaries have been determined, the statistical evaluation of analytical data described for the mud pits within the berms will be applied to the contaminated area outside of the berm. 


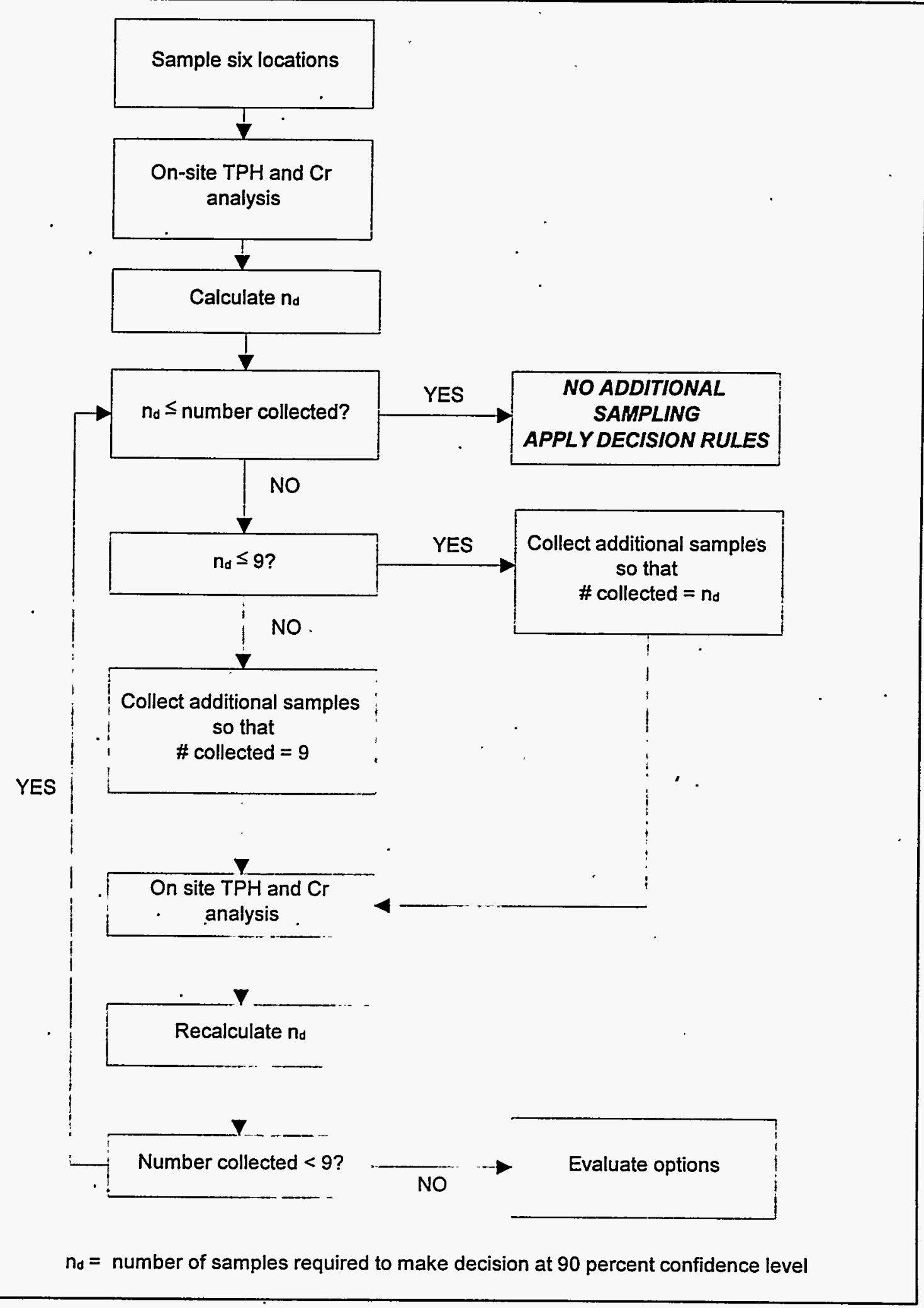

Figure 3-1

Sampling Flowchart, Central Nevada Test Area Mud Pits 


\subsection{Shaker Pad Areas and Mud/Grout Piles}

The shaker pad areas are similar to the mud pits subsites outside of breached berms since, in both cases, the areas are not controlled by engineered structures. Because of this, the decision rules for the shaker pad areas are essentially the same as the decision rules for the mud pits subsites outside of breached berms described in the previous section.

\subsection{Drilling Mud/Grout Piles}

The primary decision to be made for the drilling mud/grout piles is whether the material in the piles can be removed and disposed of as inert construction debris, or whether it requires handling as some other type of waste. If the concentrations of all contaminants of potential concern in a drilling mud/grout pile are below preliminary action levels, then the material will be handled as construction debris. If the concentration of any contaminant of potential concern equals or exceeds its preliminary action level, then a limited number of remedial alternatives will be evaluated, and an appropriate alternative will be selected based on the type(s) and concentration(s) of contaminants encountered.

\subsubsection{Miscellaneous Surface Sites}

The primary goals of the scrap and trash dump and the suspected burn area investigation are to find the dump and to confirm that the material that appears to be burned is part of the liner from the decontamination facility pit. Upon completion of the investigation, the scrap and trash dump (if found) and the suspected burn area adjacent to the decontamination facility pit will be added to the list of ER housekeeping sites and will be addressed along with the other housekeeping sites.

If the two protruding pipes north of UC-3 are found to be associated with a UST, samples will be collected from inside of the tank to determine if the tank contained petroleum products and from the soils adjacent to the tank to determine if the tank has leaked.

\subsubsection{Additional Decision Rules}

It is possible that unexpected conditions will be encountered that will necessitate field decisions to change the investigation approach for CNTA or will necessitate a stop in work. For example, if radiological screening of samples from UC-1 mud pit 1D are significantly above background, those samples will be sent to an off-site fixed laboratory for analysis instead of the on-site mobile laboratory. Most operational stop-work issues will be addressed in the site-specific HASP and 
QAPP. Section C.2 of Appendix C provides a detailed description of the decision rules established for the on-site analytical system. If conditions at the site are substantially different than expected, so that the data collected during the investigation as currently proposed would clearly not be useful for supporting the decision-making process, the work will be terminated, NDEP will be notified, and the investigation will be rescoped.

\subsubsection{Specification of Limits on Decision Errors}

\subsubsection{Mud Pits, Shaker Pad Areas, and Drilling Mud/Grout Piles}

Based on existing information, it currently is assumed that the mud pits, shaker pad area soils, and drilling mud/grout piles contain levels of contaminants (TPH and/or chromium) that exceed action levels (the "null hypothesis" for statistical testing). The primary decision errors in implementing the mud pit, shaker pad area, and drilling mud/grout pile investigation portion of the CNTA CAIP are deciding that no further action is required when concentrations of contaminants of potential concern actually exceed preliminary action levels (a false positive error) or deciding that active remedial action is required when concentrations of all contaminants of potential concern are actually below preliminary action levels (a false negative error).

The primary consequence of a false positive error is that contamination would remain in place without controls and potential threats to human heaith and the environment would continue. The primary consequence of a false negative error would be spending funds on active remediation when no remedial action was required.

Control of potential errors depends foremost on the accuracy of the assumptions made for the CASs because these assumptions are used to design the sampling and analysis program. If the assumptions are accurate, the sampling and analysis program generally will provide adequate data for supporting decisions. The decision error rate goal for the surface investigation portion of this project has been set at no more than a 10 percent chance of making a decision error.

The sampling program for the CNTA surface investigation has been designed to provide data to allow statistical determination of whether an appropriate number of samples has been collected to support application of the decision rules at the specified level of confidence ( 90 percent, which is equivalent to the 10 percent decision error rate goal identified above). This determination will be made using the procedures described in Chapter 6 of the EPA publication Methods for 
Evaluating the Attainment of Cleanup Standards, Volume 1: Soils and Solid Media (EPA, 1989). The mean concentration (or activity for radionuclides) and standard deviation of each targeted analyte detected in the soil and drilling mud samples from each mud pit and shaker pad study. area will be used to calculate the number of samples necessary to make the determination at the 90 percent confidence level. If the calculated number of samples is less than or equal to the number of samples actually collected, no additional samples would be required to support the decision with no more than a 10 percent chance of making a decision error. If the calculated number of samples is greater than the number actually collected, then either additional samples can be collected to meet the specified level of confidence, or the decision could be made with the level of confidence calculated for the number of samples collected. Appendix $\mathrm{C}$ provides a more detailed discussion of the statistical sampling design.

\subsubsection{Optimization of the Design for Obtaining Data}

The sampling and analysis approaches for the CNTA surface investigation described in Section 4.0 and Appendix $\mathrm{C}$ of this CAIP were developed to optimize the design for obtaining data to meet the data quality objectives for the site. If these approaches result in insufficient data to support the decisions to be made, the DQO process will be evaluated.

\subsubsection{Technical Approach}

The technical approach for the surface investigation sampling and analysis program is described in detail in Appendix C. 


\subsection{Corrective Action Investigation Sampling and Analysis}

\section{Tasks}

This section of the CAIP describes the methodology for the investigation of CNTA surface CASs. The DQO process has been implemented in order to design a data collection program that will support the site's data needs and to supply sufficient site characterization information to make a decision concerning remedial action and closure. The principals of ESC will guide the overall investigation to the degree that it is applicable. All sampling activities will be conducted in compliance with the Industrial Sites $Q A P P(\mathrm{DOE}, 1996)$ and all applicable approved procedures. Requirements for field and laboratory environmental sampling QA/QC are contained in the Industrial Sites QAPP (DOE, 1996).

\subsection{Geophysical Surveys}

Surface geophysical surveys will be conducted over the entire disturbed areas at UC-1, UC-3, and UC-4. The targets of these surveys are the covered mud pits, shaker pad areas, scrap and trash dump, and protruding pipes. Surface geophysical surveys will be used to aid in locating backfilled mud pits, determine mud pit boundaries, locate spilled mud in the vicinity of shaker pads and breached mud pit berms, characterize pit contents (e.g., buried metal), select locations to begin chemical sampling, and provide a limited amount of near-surface stratigraphic information. In addition, intrusive soil electrical conductivity measurements will be taken using a Geoprobe ${ }^{\circledR}$ conductivity logging system. This instrument will be used to provide depth-to-mud and mud thickness data not determinable from the surface geophysical systems. .

A $6 \mathrm{~m} \mathrm{x} 6 \mathrm{~m}$ ( $20 \mathrm{ft} \times 20 \mathrm{ft})$ grid will be installed over each UC area. Steel stakes will be placed at the four corners of each grid, and their locations will be determined with respect to the coordinate system currently used at the CNTA. The grid will be used to guide the acquisition of data. Four electromagnetic induction (EM) systems and ground-penetrating radar (GPR) will be used. In addition, a magnetometer will be used to assist in assessing the presence of a buried tank near the protruding pipes at UC-3. Continuous EM measurements will be taken and recorded digitally over the grid. GPR profiles will be acquired over selected areas of interest. 


\subsection{Mud Pits, Shaker Pad Areas, and Drilling Mud/Grout Piles Investigation}

\subsubsection{Mud Pits}

Each mud pit will be divided into six equal-area sections by bisecting the mud pit along the long dimension and trisecting the mud pit along the short dimension (Figures 4-1 through 4-5). The initial six sampling locations for each pit will be in the center of each section. The remaining three sampling locations (if needed) will be at the grid nodes (two locations) and the center of the mud pit (one location).

Samples will be collected from the mud pits by means of a truck- or skid-mounted Geoprobe ${ }^{\otimes}$ system capable of collecting continuous core samples. At the first location in each mud pit, if depth-of-mud information has not been previously acquired by geophysical measurements, the core barrel will be advanced from the ground surface to a depth of ten feet to allow identification of the thickness of mud in the pit. At subsequent locations in the mud pit, the core barrel will be advanced to at least one foot into the native soils below the bottom of the drilling mud or until refusal, whichever is shallower.

If several borings at each location are necessary to collect an adequate volume of soil for the required analyses, additional borings will be advanced in a circular pattern around the first boring location at a distance interval of not greater than one foot.

Materials collected from the core barrel will be described by a field geologist. A description of the retrieved materials will include:

- Color

- Odor (specifically, petroleum odor)

- Visual soil classification (grain size)

- Relative moisture (dry to wet)

- Relative density (loose to hard)

- Unified Soil Classification System symbol

- Type of materials - fill or natural

- Depth interval of sample collected

- Contact between drilling mud and native materials

- Nature of material - stratified or massive

The cores extracted at each sampling location will be split into samples representing two-foot depth increments from the ground surface to two feet below the bottom of the drilling mud. If 


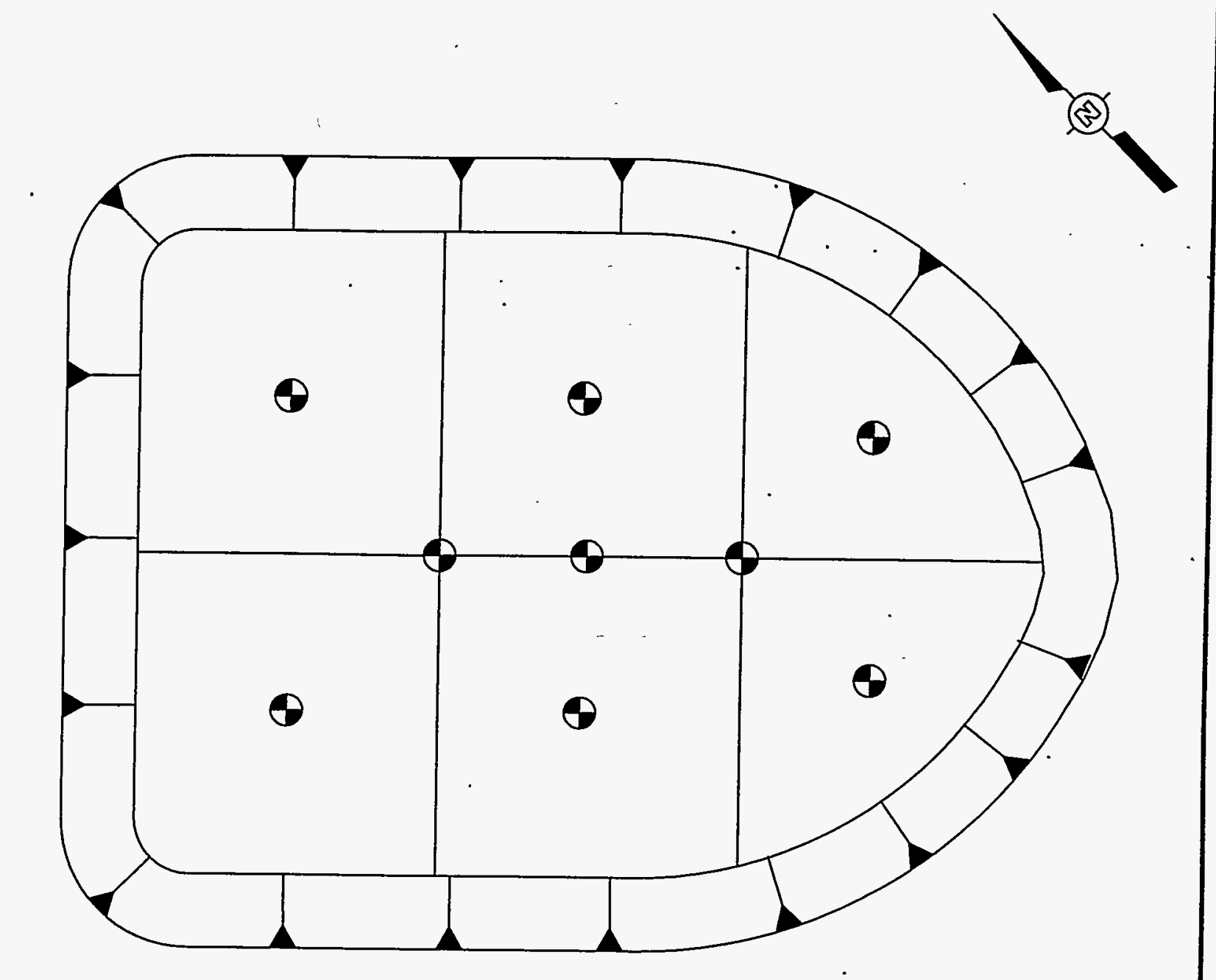

ㅎํำ
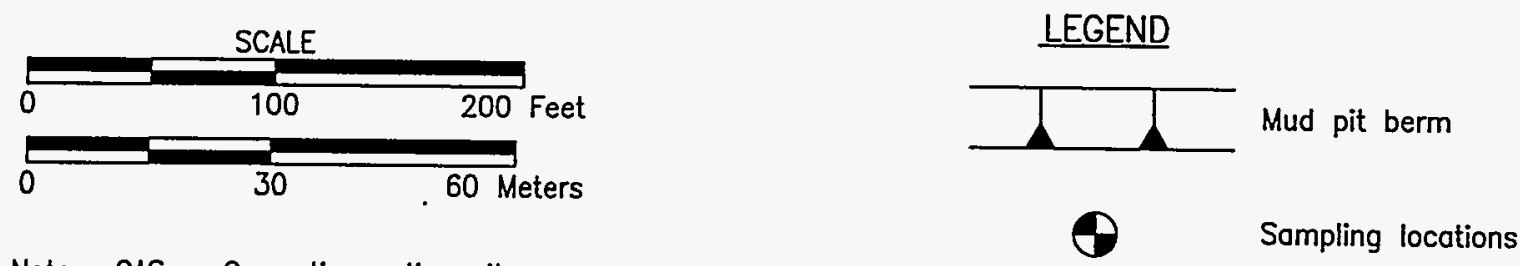

Note: $\quad C A S=$ Corrective action site

Compiled and modified from: Fenix \& Scisson, 1968,

U.S. Atomic Energy Commission, 1973, and

1968 and 1993 CNTA Aerial Photographs from

DOE/NV Remote Sensing Loboratory

Figure 4-1

Sampling Locations, Central Mud Pit

4-3 


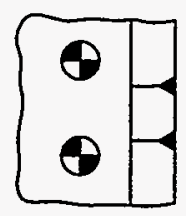

Pit $1 \mathrm{~A}$

CAS 58-09-02

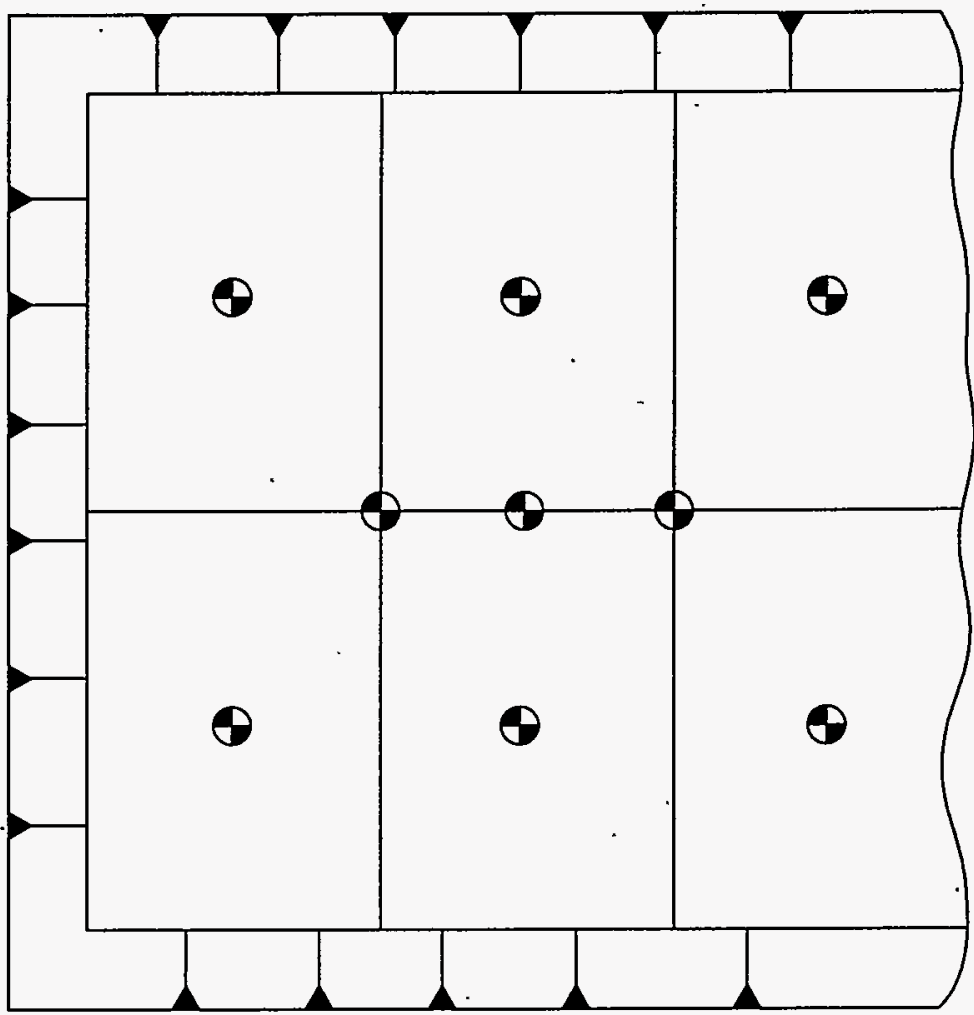

Pit 18

CAS 58-09-04

LEGEND

\section{SCALE}
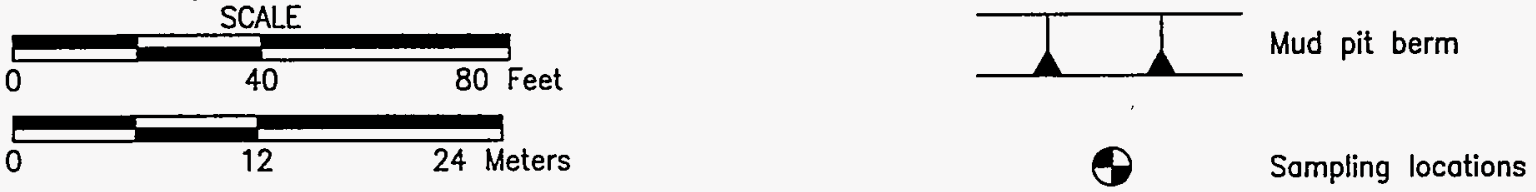

Note: $\quad$ CAS $=$ Corrective action site

Compiled and modified from: Fenix \& Scisson, 1968,

U.S. Atomic Energy Commission, 1973, and 1968 and 1993 CNTA

aerial photographs from DOE/NV Remote Sensing Laboratory

Figure 4-2

Sampling Locations, Additional Mud Pits at UC-1

4-4 


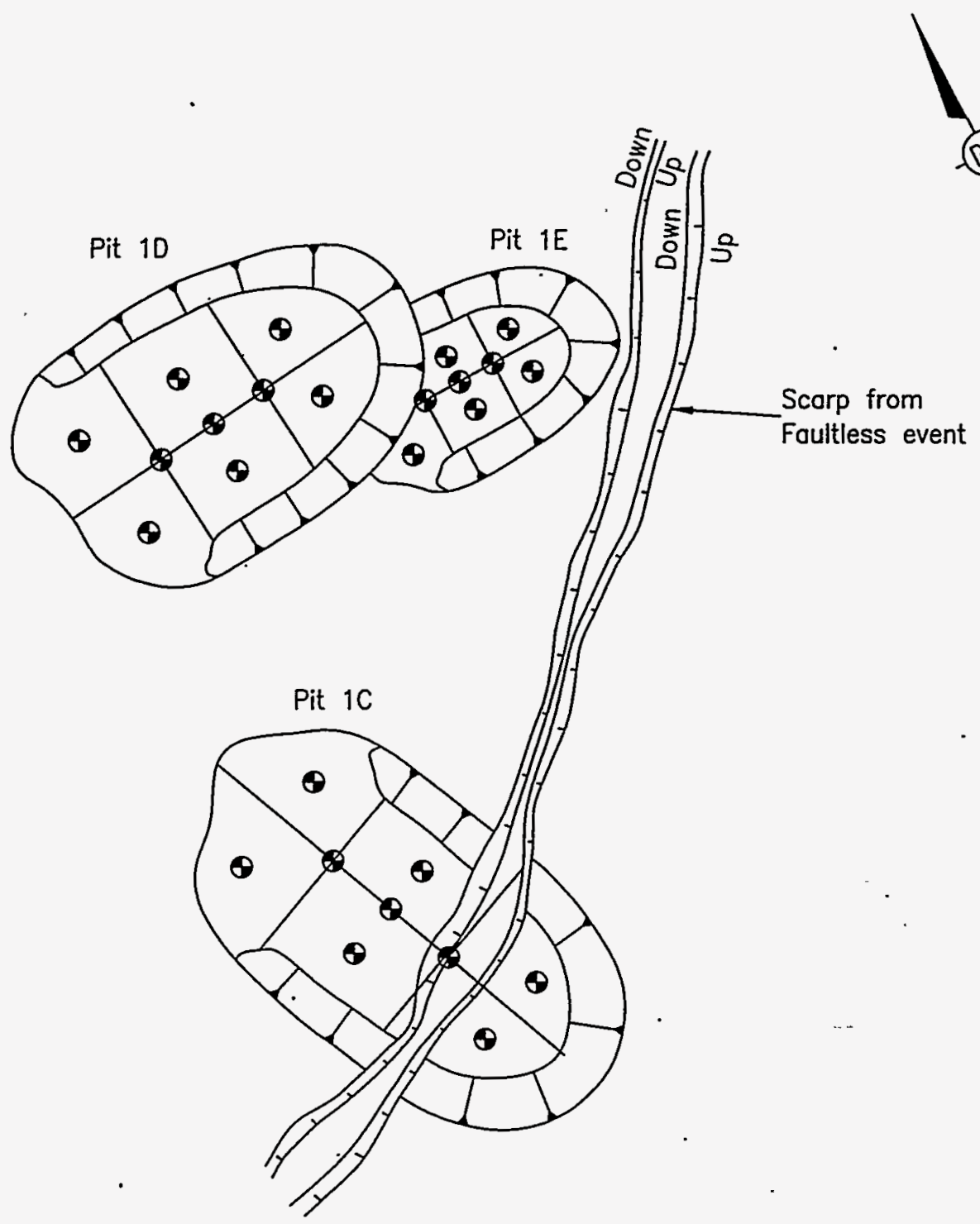

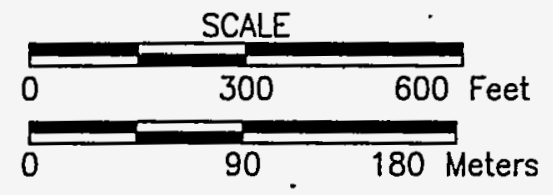

Note: CAS $=$ Corrective action site

Modified from: 1993 aerial photogroph from DOE/NV Remote Sensing Laboratory

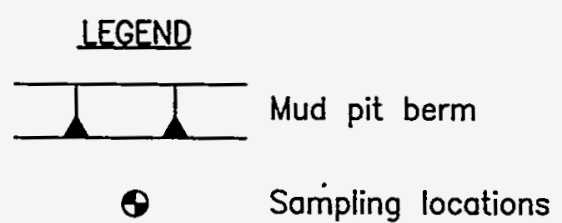

Figure 4-3

Sampling Locations, UC-1 Mud Pits

$$
\text { 4-5 }
$$




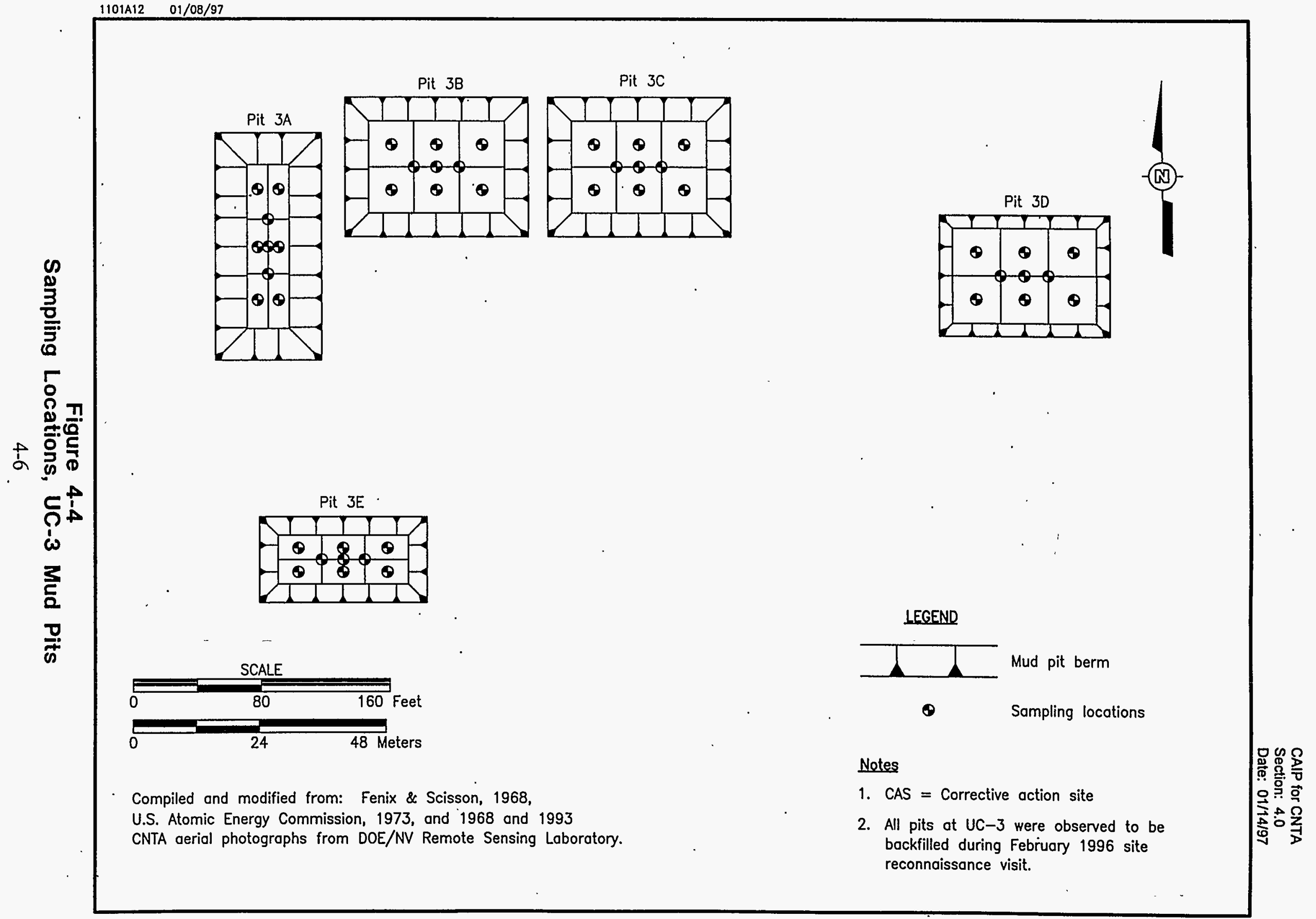




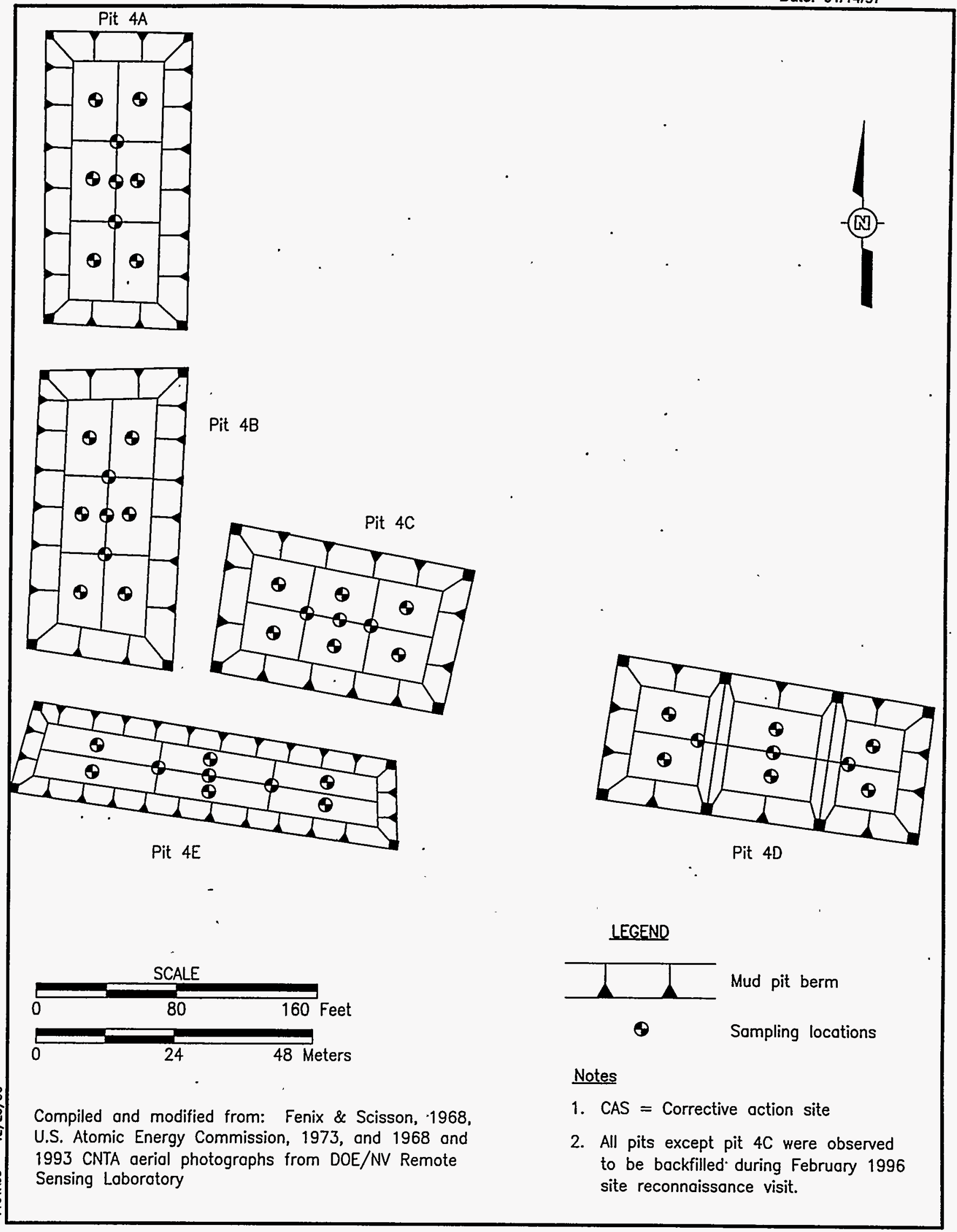

Figure 4-5

Sampling Locations, UC-4 Mud Pits 
multiple cores are needed to obtain the required sample volumes, the samples from the desired depth increment from each boring will be composited into one uniform sample representing that depth increment.

After collection of each sample, the core barrel will be decontaminated using approved procedures; and at the completion of sampling at each location, the cutting shoe, barrel, stop pin, and drive rods also will be decontaminated using the same process. Decontamination fluids will be containerized for later disposal in accordance with all applicable regulations. Upon completion of sampling, the Geoprobe ${ }^{\circledR}$ soundings will be backfilled with bentonite pellets.

The samples collected from pit ID at UC-1 (Figure 4-3) will be screened with portable alpha and beta/gamma detectors. If the screening results are significantly above background, the samples from pit $1 D$ will be sent to an off-site fixed laboratory for all analyses.

All samples collected will be analyzed for TPH and hexavalent chromium. Analyses for both TPH and chromium will be conducted in an on-site mobile laboratory. The laboratory will provide definitive quality data in accordance with regulatory-approved and standardized methods and quality assurance. Performance evaluation (PE) samples will be analyzed in the mobile laboratory and by an off-site referee laboratory.

Three samples from each mud pit representing the depth interval(s) where TPH and/or hexavalent chromium exceeds its preliminary action level will be submitted to an off-site fixed laboratory for T.CLP-extractable volatiles, semivolatiles, and metals analyses. If the radiological screening results for the samples collected from pit $1 \mathrm{D}$ at UC-1 are significantly above background, those samples also will be analyzed for gross alpha/beta, gamma spectroscopy, and tritium by an off-site fixed laboratory. A summary of the collected samples (including the estimated number of field duplicates) and the analytical methods to be used is presented in Table 4-1, and sample handling is discussed in Section 4.2.5. It should be noted that the sample numbers included in Table 4-1 are the maximum number to be collected inside the mud pits, based on sampling.at all nine proposed sampling locations at each pit. The number of samples to be collected outside the mud pits near breached berms cannot be estimated at this time due to the unknown extent of the affected areas. The number of samples to be collected for TCLP analyses also cannot be estimated at this time. 
Table 4-1

CNTA Surface Sites Sampling Requirements

\begin{tabular}{|c|c|c|c|c|c|c|}
\hline $\begin{array}{l}\text { Sample } \\
\text { Location }\end{array}$ & $\begin{array}{c}\text { Number } \\
\text { of } \\
\text { Samples }\end{array}$ & Sample Type & $\begin{array}{l}\text { Constituent of } \\
\text { Concern }\end{array}$ & $\begin{array}{l}\text { Analytical } \\
\text { Method }\end{array}$ & $\begin{array}{l}\text { Container Type and } \\
\text { Volume Required }\end{array}$ & Preservative \\
\hline $\begin{array}{l}\text { Mud Pit } \\
\text { Samples }\end{array}$ & 625 & Soil Grab & TPH & $8015 \mathrm{M}$, Diesel $^{\mathrm{a}}$ & $\begin{array}{l}\text { 8-oz. glass with poly- } \\
\text { lined cap }\end{array}$ & Cool to $4^{\circ} \mathrm{C}$ \\
\hline $\begin{array}{l}\text { Mud Pit } \\
\text { Samples }\end{array}$ & 625 & Soil Grab & $\begin{array}{l}\text { Total and hex. } \\
\text { Chromium }\end{array}$ & $7196^{a}, 7190$ & 8-02. glass & Cool to $4^{\circ} \mathrm{C}$ \\
\hline $\begin{array}{l}\text { Shaker Pad } \\
\text { Area Soils }\end{array}$ & TBD & Soil Grab & TPH & 8015M, Diesel ${ }^{a}$ & $\begin{array}{l}\text { 8-oz. glass with poly- } \\
\text { lined cap }\end{array}$ & Cool to $4^{\circ} \mathrm{C}$ \\
\hline $\begin{array}{l}\text { Shaker Pad } \\
\text { Area Soils }\end{array}$ & TBD & Soil Grab & $\begin{array}{l}\text { Total and hex. } \\
\text { Chromium }\end{array}$ & $7190^{a}$ & 8-oz. glass & Cool to $4^{\circ} \mathrm{C}$ \\
\hline $\begin{array}{l}\text { Drilling } \\
\text { Mud/Grout } \\
\text { Piles }\end{array}$ & 12 & Soil Grab & TPH & $8015 \mathrm{M}$, Diesel ${ }^{a}$ & 8-0z. glass & Cool to $4^{\circ} \mathrm{C}$ \\
\hline $\begin{array}{l}\text { UC-1 } \\
\text { Mud Pit 1D } \\
\text { Samples }\end{array}$ & 48 & Soil Grab & $\begin{array}{l}\text { Gross } \\
\text { Alpha/beta } \\
\text { Gamma spec } \\
\text { Tritium }\end{array}$ & $\begin{array}{l}\text { SM } 7110^{b} \\
\text { HASL300 } \\
4.5 .2 .3^{\mathrm{C}} \\
\text { EERF } \mathrm{H}-01^{\mathrm{d}}\end{array}$ & $\begin{array}{l}\text { 4-oz. glass or poly } \\
8-0 z \text {. glass or poly } \\
8-0 z \text { glass or poly }\end{array}$ & $\begin{array}{l}\text { none } \\
\text { none } \\
\text { none }\end{array}$ \\
\hline Potential UST & 4 & Soil Grab & TPH & 8015M, Diesel ${ }^{\mathrm{a}}$ & 8-0z. glass & Cool to $4^{\circ} \mathrm{C}$ \\
\hline
\end{tabular}

${ }^{2}$ EPA SW-846, Test Methods for Evaluating Solid Waste, $3^{\mathrm{d}}$ Edition, modified according to the California State Water Resources Control Board, Leaking Underground Fuel Tank Field Manual, Guidelines for.Site Assessment, Cleanup, and Underground Storage Tank Closure; Appendix B (EPA, 1996b)

American Public Health Association, Standard Methods for the Examination of Water and Wastewater (APHA, 1992)

CU.S, Department of Energy Environmental Measurements Laboratory Procedure Manual, HASL-300 (DOE, 1992a)

U.S. Environmental Protection Agency (EPA) Eastern Environmental Radiation Facility (EPA, 1984)

$T B D=$ To Be Determined through judgmental sampling of targeted areas

oz. = Ounce

${ }^{\circ} \mathrm{C} \quad=$ Degree(s) Celsius

\subsubsection{Shaker Pad Area Investigation}

Initial locations will be sampled at two-foot depth increments from the ground surface to four feet, or to a different target depth if indicated from geophysical measurements. If a distinct layer of TPH contamination is found, either visually or by analysis, samples will be collected only from that depth interval and the underlying two-foot depth interval at subsequent sampling locations, as described in Appendix C. Table 4-1 includes the targeted analytes for the shaker pad areas. The total number of samples to be collected from the shaker pad areas cannot be estimated at this time due to the unknown extent of the sampling area. 


\subsubsection{Drilling Mud/Grout Piles}

The samples will be collected with either a disposable or a decontaminated stainless steel trowel or spoon. Sample handling and analysis procedures will be the same as those described for the mud pits. Table 4-1 includes the estimated number of samples and targeted analytes for the drilling mud/grout piles.

\subsubsection{Potential Underground Storage Tanks}

If the two protruding pipes north of UC-3 are associated with a UST, two soil samples will be collected from the elevation of the bottom of the tank using the Geoprobe ${ }^{\circledR}$. In addition, a hand auger will be used to collect two samples from inside of the tank, if possible. The samples will be analyzed for TPH by the on-site laboratory.

\subsubsection{Sample Handling}

Field QC will be maintained by performing all field activities in accordance with standardized operating procedures, quality practices, and guidance established in the QAPP (DOE, 1996). QC samples will be collected to analyze for possible contamination and to evaluate precision and accuracy of analysis associated with sample collection activities. Field duplicate, equipment rinsate blank, and field blank samples will be collected according to approved procedures and the QAPP. Each type of field QC sample will be collected and analyzed at a frequency of one per site or one per 20 samples at each site.

Soil samples will be handled, packaged, and shipped in accordance with approved procedures. Shipping containers and filled sample bottles will be radiologically screened and shipped in accordance with U.S. Department of Transportation (DOT) regulations. Sample containers will be obtained from an approved laboratory and certified clean per EPA protocol. Sample bottles will remain sealed until used.

Documentation of sampling events will be sufficient to demonstrate that samples have been obtained from the locations stated and that they have reached the laboratory without alteration except by required preservation. Field activities, sample collection, and sample custody will be documented in accordance with approved procedures. Custody refers to the method by which sample history is tracked and continuous possession of samples by approved custodians is documented. A legally defensible written record of sample custody from the time of collection through disposal will be maintained. 


\subsection{Waste Management Plan}

Management of investigation-derived waste will be based on regulatory requirements, field observations, and the results of DOE-approved, laboratory analysis of site characterization samples. Administrative controls (decontamination procedures and characterization strategies) will minimize hazardous waste generated during site investigation activities.

Hazardous and/or mixed waste, if it is generated, will be managed and disposed of in accordance with DOE Orders, DOT requirements, NDEP regulations, RCRA regulations, agreements and permits between DOE and NDEP, and site-specific requirements. Decontamination activities will be performed according to approved procedures specified in the contractor field sampling instructions and will be written considering the contaminants of concern present at the site.

\subsection{Waste Minimization}

Characterization activities have been planned to minimize the amount of IDW generated. The planned field technique will generate minimal soil waste in the form of cuttings. Soil waste generated that does not require management as radioactive or RCRA-regulated waste will be left at the site and used in site recontouring operations and/or construction of berms. Other waste, such as disposable sampling and personal protective equipment, will be segregated to the greatest extent possible to avoid generation of hazardous, radioactive, or mixed waste. Hazardous materials will be controlled, minimizing generation of hazardous or mixed waste.

\subsection{Potential Waste Streams}

Based on preliminary sampling results of similar type sites and process knowledge, no mixed or transuranic waste streams are expected. It is likely that low-level, hydrocarbon, hazardous, and/or sanitary wastes will result from field activities. Potential waste constituents include tritium, other man-made radionuclides, petroleum hydrocarbons, and solvents used for sample extraction by the on-site mobile laboratory. Wastes generated during the surface investigation may include, but are not limited to:

- Decontamination rinsate

- Disposable sampling equipment (plastic, paper, sample containers, aluminum foil, etc.)

- Personal protective equipment (PPE)

- Spent samples and extraction media used by the on-site mobile laboratory 
Wastes generated by laboratory operations will be managed separately from those generated by general site characterization activities. For example, waste PPE generated through contact with soil will be segregated from waste PPE generated from laboratory operations. In addition, spent samples and extraction media used by the on-site mobile laboratory will be segregated.

\subsection{Sanitary Waste Management}

Sanitary waste will be contained in plastic bags, dumpsters, or drums and transported to a sanitary waste landfill. Soils that are not regulated or are below low-level waste limits for radioactivity will be left on site.

\subsection{Low-Level Waste Management}

Low-level waste (LLW) will be managed in accordance with DOE Orders and the requirements of the Nevada Test Site Defense Waste Acceptance Criteria, Certification, and Transfer Requirements, NVO-325, Rev. 1 (DOE, 1992b). Liquid LLW, if any, will be evaporated on site. Solid IDW, such as sampling equipment and PPE, will be placed in plastic bags with an attached waste tracking tag in accordance with Standard Quality Practices. The bags will be placed in DOT-compliant drums (49 CFR 172), which will be properly labeled and locked or fitted with tamper-indicating devices. The drums will be staged at a designated Radioactive Materials Area pending disposal under NVO-325 criteria at the NTS (DOE, 1992b).

\subsection{Hazardous Waste Management}

Suspected hazardous wastes will be managed in accordance with RCRA and State of Nevada hazardous waste management regulations, interpreted as follows. Suspected hazardous wastes will be placed in DOT-compliant drums (49 CFR 172), which will be locked or fitted with tamper-indicating devices. The containers shall be compatible with the waste in accordance with the requirements of 40 CFR 265.172. Containers shall be handled and inspected in accordance with the requirements of 40 CFR 265.173 and 174, respectively. Based on process knowledge, incompatible wastes shall be managed in accordance with 40 CFR 265.177 (i.e., shall not be placed in the same container, and shall be separated such that in the event of a spill, leak, or release); incompatible wastes shall not contact one another. Wastes shall be containerized in a manner to comply with Subpart CC of 40 CFR 265.

Wastes shall be characterized in accordance with the requirements of 40 CFR 261.

Characterization will be based on laboratory results, process knowledge, or a combination thereof. Wastes pending characterization will be marked with "Hazardous Waste - Pending 
Analysis" stickers until its regulatory status can be determined through evaluation of laboratory results. Waste shall be traceable to its source and/or samples considered analogous to the waste (such as waste drill core associated with a sample). Traceability shall be maintained by numbering containers and keeping appropriate records which trace waste to samples, areas, or products. After receipt of analytical results, hazardous wastes will be labeled and marked in . accordance with the requirements of 40 CFR 262.32, and State of Nevada requirements such as . writing the EPA Waste Code on the hazardous waste label.

Hazardous wastes will be accumulated at the site of generation for less than 90 days in accordance with 40 CFR 262.34. Prior to 90 days after the accumulation start date as specified in 40 CFR 262.34(a) or generation of wastes in excess of quantity limits specified in 40 CFR 262.34(c)(1), the waste will be shipped to a permitted hazardous waste treatment, storage, or disposal facility. The waste will be shipped by an appropriately licensed and permitted hazardous waste hauler. A Uniform Hazardous Waste Manifest shall be completed prior to shipping hazardous waste in accordance with the requirements of 40 CFR 262.20, $262.21,262.22$, and 262.23. A copy of the manifest shall be provided to the State of Nevada in accordance with state regulatory requirements.

\subsection{Hydrocarbon Waste Management}

Hydrocarbon waste (containing more than 100-parts per million (ppm) total petroleum hydrocarbons [TPH]) will be properly containerized in bags or drums and will be transported to an appropriately permitted hydrocarbon waste management facility after the waste is fully characterized.

\subsection{Mixed Waste Management}

Mixed waste shall be managed in accordance with RCRA (40 CFR 262) and State of Nevada (NRC 444) regulations, as well as DOE requirements for radioactive waste, interpreted as follows. Where there is conflict in regulations or requirements, the most stringent shall apply. For example, the 90-day accumulation time limit and weekly inspections per RCRA regulations will be applied to mixed waste even though it is not required for radioactive waste. Conversely, while RCRA does not require traceability through the use of waste tracking tags, the waste acceptance program for LLW does; therefore, waste tracking tags shall be used for nonliquid waste. In general, mixed waste shall be managed in the same manner as hazardous waste. Suspected mixed waste will be managed in accordance with applicable regulations and requirements and will be marked with "Awaiting Analysis" stickers pending characterization 
and confirmation of its regulatory status. However, mixed waste shall be transported to the Nevada Test Site transuranic waste storage pad for storage pending treatment or disposal.

Mixed waste with hazardous waste constituents below land disposal restrictions may be disposed of at the Area 5 Radioactive Waste Management Site under interim status. Mixed waste not meeting land disposal restrictions will require development of a treatment plan under the requirements of the Mutual Consent Order between DOE and the State of Nevada (Mutual Consent Agreement, 1995). 


\subsection{Time Frame and Reporting}

\subsection{Schedule}

Field work will begin after the approval of this CAIP by the NDEP. Upon approval of this plan, NDEP will be notified of the scheduled start date for the field activities at least 10 working days. prior to the start of field work. The expected completion time frame, in working days, is:

- Day 0: Mobilize surface geophysics crew to the site.

- Day 7: Mobilize conductivity logging probe and crew to the site.

- Day 14: Complete surface and intrusive geophysical surveys.

- Day 42: Mobilize sampling equipment and mobile laboratory and crews to the site.

- Day 70: Complete surface sites investigation.

- Day 101: Receive analytical performance evaluation results for on-site and referee off-site labs.

- Day 101: Quality-assured analytical data from on-site laboratory available.

Factors beyond DOE/NV's control, such as weather or delays in receipt of laboratory results, may delay field activities. If such delays occur, NDEP will be notified verbally.

\subsection{Reporting}

Within eight months of receipt of validated analytical results from the final field activities, a Corrective Action Decision Document will be submitted to NDEP. The document will, at a minimum, include the following:

- Drawings of the site, including appropriate site boundaries, sampling locations, estimated boundaries of contamination (if applicable), and other relevant features

- Discussions of the characterization methods used, including soil sampling methods, materials, and logs

- Information regarding the presence and concentrations of constituents of concern

- Tables summarizing laboratory and field-screening data . 
- Discussion regarding the adequacy of the characterization of the site

- Discussion regarding the quality control data obtained for the characterization

- Recommendations for further assessment, remediation, or closure of the site

- Photo documentation

In addition to the aforementioned scheduled deliverables, the DOE will notify the NDEP as soon as it is practicable of any findings that will require the alteration of this plan or that will have a major impact on potential remedial action for the site and/or human health and the environment. 


\subsection{References}

AEC, see U.S. Atomic Energy Commission.

APHA, see Americal Public Health Association.

American Public Health Association. 1992. Standard Methods for the Examination of Water and Wastewater. 18th Edition. Washington, DC.

CFR, see Code of Federal Regulations.

Code of Federal Regulations. 1995. 40 CFR Part 136. Washington, DC: U.S. Government Printing Office.

Code of Federal Regulations. 1995. 40 CFR Part 161. Washington, DC: U.S. Government Printing Office.

Code of Federal Regulations. 1995. 40 CFR Part 172. Washington, DC: U.S. Government Printing Office.

Code of Federal Regulations. 1995. 40 CFR Part 260. Washington, DC: U.S. Government Printing Office.

Code of Federal Regulations. 1995. 40 CFR Part 261. Washington, DC: U.S. Government Printing Office.

Code of Federal Regulations. 1995. 40 CFR Part 262. Washington, DC: U.S. Government .Printing Office.

Code of Federal Regulations. 1995. 40 CFR Part 265. Washington, DC: U.S. Government Printing Office.

DRI, see Desert Research Institute.

Desert Research Institute. 1988. CERCLA Preliminary Assessment of DOE's Nevada Operations Office Nuclear Weapons Testing Areas. Las Vegas, NV.

DOE, see U.S. Department of Energy.

Eberline, see Eberline Instrument Corporation. 
Eberline Instrument Corporation. 1973. Radiation Contamination Clearance Report for Central Nevada Test Area, NVO-294-10. Prepared for U.S. Atomic Energy Commission, Nevada Operations Office. Las Vegas, NV.

EPA, see U.S. Environmental Protection Agency.

FFACO, see Federal Facility Agreement and Consent Order.

Federal Facility Agreement and Consent Order. 1996. Agreed to by the U.S. Department of Energy, the State of Nevada, and the U.S. Department of Defense.

Fenix \& Scisson, Inc. 1968. "Mud Pits \& Sections Map for UC-3." Prepared for the U.S. Atomic Energy Commission, Nevada Operations Office. Las Vegas, NV.

Fenix \& Scisson, Inc. 1973. Abandonment of Drilled Holes, Central Nevada Test Area. Prepared for the U.S. Atomic Energy Commission, Nevada Operations Office: Las Vegas, NV.

Gilbert, Richard O. 1987. Statistical Methods for Environmental Pollution Monitoring. New York, NY: Van Nostrand Reinhold.

Mutual Consent Agreement for the Storage of Low-LevelLand Disposal Restricted Mixed Waste, June 6, 1995.

NAC, see Nevada Administrative Code.

Nevada Administrative Code. 1995. Chapter 444. Carson City, NV.

Nevada State Environmental Commission. 1996. Amendment to Chapter 445A of the Nevada Administrative Code. Submitted to the Legislative Counsel Bureau for filing on September 13, 1996.

REECo, see Reynolds Electrical \& Engineering Co., Inc.

Remote Sensing Laboratory. 1968. Aerial photographs of the Central Nevada Test Area. RSL is operated by Bechtel Nevada for DOE/NV. Las Vegas, NV.

Remote Sensing Laboratory. 1993. Aerial photographs of the Central Nevada Test Area. RSL is operated by Bechtel Nevada for DOE/NV. Las Vegas, NV.

Reynolds Electrical \& Engineering Co., Inc. 1986. Hazardous Waste Installation Assessment Report. Prepared for DOE by D.N. Fauver. Las Vegas, NV: Reynolds Electrical \& Engineering Co., Inc. 
RSL, see Remote Sensing. Laboratory.

U.S. Atomic Energy Commission, Nevada Operations Office. 1973. Planning Directive: Demobilization, Restoration and Monitoring, Central Nevada Test Area, NVO-90. Prepared by Fenix and Scisson. Las Vegas, NV.

U.S. Atomic Energy Commission, Nevada Operations Office. 1974. Summary Report: Central Nevada Test Area Demobilization and Restoration Activities, NVO-52. Prepared by Holmes and Narver. Las Vegas, NV.

U.S. Department of Energy. 1992a. Environmental Measurements Laboratory Procedures Manual, HASL-300, 27th Edition, Volume 1. New York, NY.

U.S. Department of Energy, Nevada Operations Office. 1992b. Nevada Test Site Defense Waste Acceptance Criteria, Certification, and Transfer Requirements, NVO-325, Rev. 1.

- Las Vegas, NV.

U.S. Department of Energy, Nevada Operations Office. 1994a. Nevada Environmental Restoration Health and Safety Plan. Las Vegas, NV.

U.S. Department of Energy, Nevada Operations Office. 1994b. Nevada Environmental Restoration Project Project Management Plan. Las Vegas, NV.

U.S. Department of Energy, Nevada Operations Office. 1994c. United States Nuclear Tests, July 1995 through September 1992, DOE/NV-209 (Rev. 14). Las Vegas, NV: IT Corporation.

U.S. Department of Energy, Nevada Operations Office. 1995. Unpublished analytical data for samples collected from the Central Mud Pit and UC-4.

U.S. Department of Energy, Nevada Operations Office. 1996. Industrial Sites Quality Assurance Project Plan, Nevada Test Site, Nevada, DOE/NV-372. Las Vegas, NV: IT Corporation.

U.S. Environmental Protection Agency. 1984. Eastern Environmental Radiation Facility Radiochemistry Procedures Manual, EPA/520/5-84/006. Washington, DC.

U.S. Environmental Protection Agency. 1989. Methods for Evaluating the Attainment of Cleanup Standards, Volume 1: Soils and Solid Media, EPÄ/230/02-89-042. Washington, DC.

U.S. Environmental Protection Agency. 1993. Data Quality Objectives Process for Superfund, EPA-540-R-93-071. Washington, DC. 
U.S. Environmental Protection Agency. 1994. Guidance for the Data Quality Objectives Process, QA/G-4. Washington, DC.

U.S. Environmental Protection Agency. 1996a. Soil Screening Guidance: Technical Background Document, EPA/540/R95/128. Washington, DC.

U.S. Environmental Protection Agency. 1996b. Test Methods for Evaluation, Solid Waste, Physical/Chemical Methods, SW-846, Third Edition: Washington, DC. 


\section{Appendix A}

\section{Expedited Site Characterization Core Team Description}





\section{Core Team Composition:}

The core decision-making team consists of a team leader and two or three technical support members.

\section{Core Team Structure:}

The core team, headed by a team leader, consists of three or four individuals with expertise in the scientific disciplines applicable to the site. For the purpose of the CNTA surface CAU corrective action investigation, the relevant scientific disciplines include geology, geophysics, environmental chemistry, and analytical chemistry. The core team leader is responsible, at a minimum, for revisions to the conceptual site model, the in-field decisions that incorporate core team members' views prior to deciding on the next sequence of measurements, and for deciding when the site characterization objectives have been achieved. The core team members manage the field activities within their respective areas of expertise, provide interpretations of the characterization results to the other core team members, and implement the core team leader's decisions. A core team member can serve in more than one area of expertise if site characteristics permit, but in no case should the core team consist of a single person. It is a key ESC concept that the exchange of views within a multidisciplinary team ensures on-site peer review of the evolving conceptual site model. The core team is supported by appropriate on-site and off-site personnel.

\section{Core Team Responsibilities:}

The core team members are responsible for the following:

- Project scoping

- Preparing a dynamic work plan that allows for on-site decision making

- Selecting site characterization technologies and qualified tèchnology providers appropriate for implementing the project

- Continuously directing and managing the ESC field activities, including the activities of other field team members (e.g., the logistics coordinator, direct push operations, sampling crews, geophysical investigations, etc.)

- Communicating field ESC results to the client

- Preparing the final report. 
It is a key to ESC's previous successes that the same core team members who are involved in the site planning also are involved in the field when field activities relevant to their core competency are occurring. Only the core team leader is necessarily involved continuously in all ESC field phases.

\section{Core Team Qualifications:}

Core team leader: The core team leader should be a mid- to senior-level individual with extensive training and experience in one or more of the scientific disciplines applicable to the site. The core team leader also must have extensive experience in managing and directing multidisciplinary teams, and in all elements and functions of contaminated site characterization projects.

Core team member: A core team member should be a mid- to senior-level individual with extensive training and experience in one of the scientific disciplines applicable to the site. In addition, a core team member must be able to communicate well with other team members with complementary technical expertise. Areas of expertise may include soil science, geology, geophysics, hydrogeology, geochemistry, analytical chemistry, environmental chemistry, or any other discipline central to understanding the site characteristics. 


\section{Appendix B}

\section{Historical Information}



SPECIFICATIONB FOP.

UENTONITE AND CHEY.ICALS

UC-3 AND UC-4

Tho spociflcations woro prepared for the United States itonic Enorgy Conmisoion, Novada Operations OfHce, by Fontx and Scisson, Inc, and Potrol eum Conbultants.

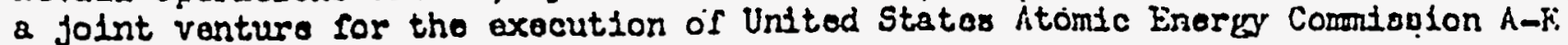
Contract $\Lambda T(26-1)-38$.

Spocifications for bentontte and chemicals to trost driling fluids required to drill holes UC-3 and UC-4, Contral Nevada Test Site, are as Collows:

Item

Bentontto

Chrame Iignosul fonate

Chrame Lignite

Caustic Soda

Soda Ash

Mica

\section{Description}

Selected, finely ground, montinorillonite clays. To bo used to form a colloidial gol that controls viscosity, gel strengths, and flitration. Kust conform to API Std. 13A, deted March 1966.

A non-caking water soluble powider to be used as a chenicul thinner for drilling muds. Lowers mud viscosity, gel strengths and improves illtration properties. Supplied in 50 pound multi-nall paper bags.

A water soluble powder to be used as a chemical thinner for drilling muds. Aids the chrome lignosul fonate in improving viscosity and gel strengths. Alds in controling the flufd loss property of drilling mud at elevated temperatures and pressures. Suppiied in 50 pound multi-wall paper bags.

Flake form, domestic, comercial grade, $98.06 \%$ sodiun hydraxide, $\mathrm{Ph}$ 12.6, supplled in 100 pound motsl drums.

Light type, grayish white powder, comercial sodium carbonate, $58 \% \mathrm{Nh}_{2} \mathrm{O}$, in accordance with $A S T M$ desigration $D-45 E-57$. Supplied in 100 pound multi-irali paper bags.

Flakes of mica that can be used when lost circulation is anticipated. The ifne particles will pass the shaker screen. hids in establishing circulation when mad returns have boen lost. ilds in building a good wall cake.

Fine Kizca

$35 \%$ retained on 40 mesh soreen $30 \%$ retained on 60 mesh screen 20\% retained on 80 mesh screen

Corrso mica

$30 \%$ retiinod on 10 mesh screen $35 \%$ retained on 20 mesh screen 15\% retained on. 40 mesh screen

Supplied in 50 pound multi-wall paper bags. 
Item

Cano and iood Fibor

Coarso Cedar Fiber

\section{Desoription}

A mixturo of cano and wood rtbars for preventing or overcoming lost circulation. Tranted to resist docomposition. Non-abrasivo. Supplied in 40 pound mult1-well paper bags.

A Iiberized redwood that does not rot, deteriorate or sour when mtxed with drilling mud. To have good matting and bridging properties. Supplied in 40 pound aulti-wall papor b8gs. 
NVO-152

\section{SUMMARY REPORT}

CENTRAL NEVADA TEST AREA

DEMOBILIZATION

AND

\section{RESTORATION ACTIVITIES}

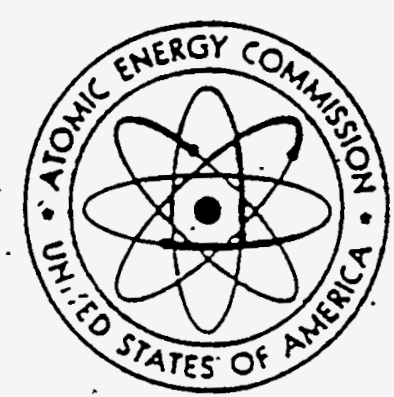

DECEMBER 1974

UNITED STATES ATOMIC ENERGY COMMISSION NEVADA OPERATIONS OFFICE

Las Vegas, Neyada

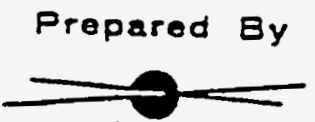

HOLMES E NARVER.INC 
fencing, iave jeen removed and the area cleaned ud. Lnder2round warer, sewer, electricai, signal, and relepnone i.ies :ere abandoned in piace. This area is locared inside the $\mathrm{CC}-3$ land witndrawal winich $\mathrm{NV}$ is retaining.

a. Scientific Cableway (RTP to Ground Zero)*

Fencing was removed and a parallel drainage ditch ias backïilled (rejer to Figure 11).

b. Trash Dumpo' (West of the RTP)*

Trash that high winds had scattered was returned to she dump. Additional trash was added after which the entire pit was backfilled.

3. UC-3, Ground Zero Area**

This area is being retained by $\mathrm{NW}$. It remains fenced (perimecer fence only). Work accomplished to dare includes the following:

a. Removal of the inner security fence.

b. Capping of the large diameter UC-3 emplacement and and canister holes with heavy concrete slabs over existing steel plates. (See Figures 12, 13, and 14.)

c. Plugging of other drilled holes (refer to Section II, paragraph $\mathrm{C}$ ).

d. Removal of all aboveground structures except for two technical buildings (long buildings) and two generator shelters which were transferred in place to the U.S. Navy in exchange for the Navy's removal from this site. Other buildings and aboveground facilities were.disposed of either through public sale or transfer to other NV contractors and/or to other government agencies.

e. A large quantity of scrap iron, resulting from drilling operations, was removed via a public sale.

f. Sumps previously used to contain drilling mud and vater were used for trash dumps and then were backfilled.

g. An initlal cleanup has been made, principally around the emplacement hole or $a$ eastern half of the fenced area.

9. Borrow Area (Aggregate Site $C$ ) **

NAR 


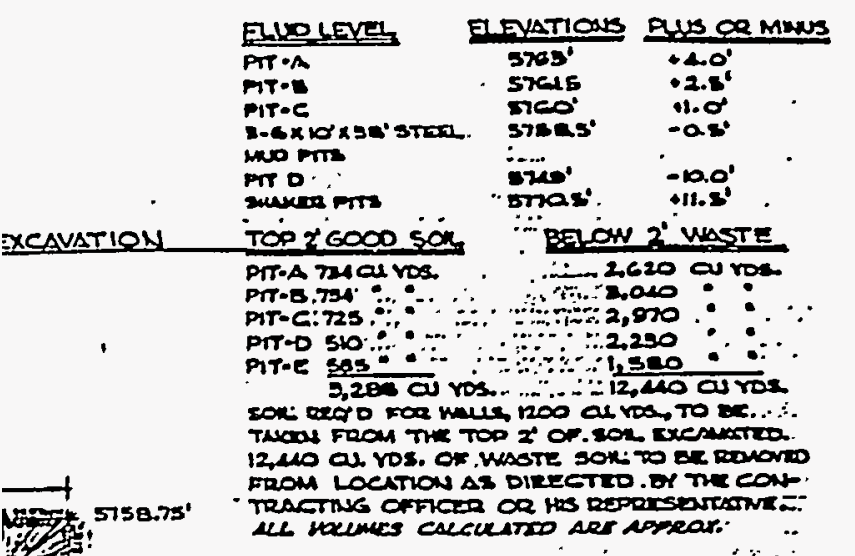

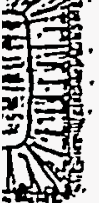

stseded

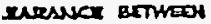

IT of 70 isproax.

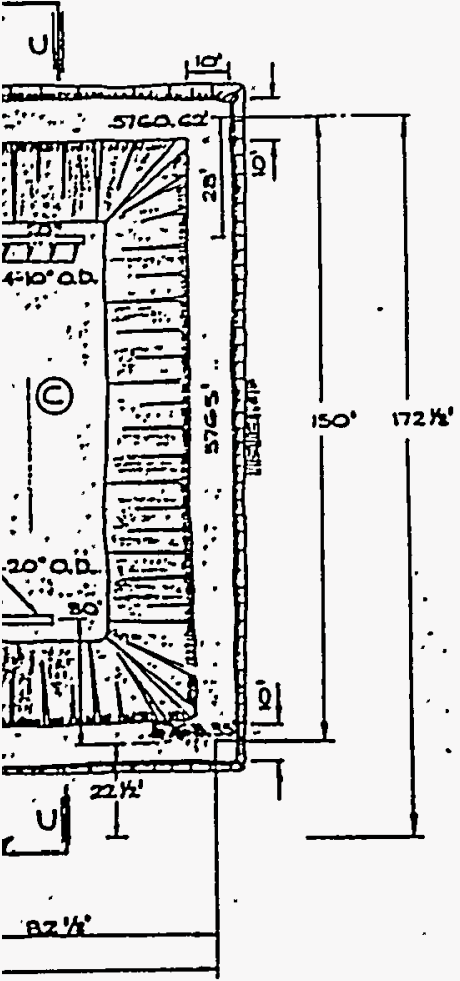

Das mo

a Nert now un

C Har oveanow lase

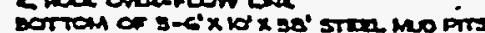
corton or contrafivese prex soos

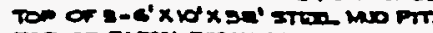

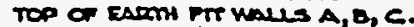

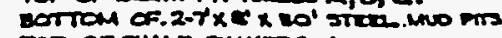
TOP of shale sureces pu. Foon.
ERATHONS: $:$ RuF or Minus: STr?

$5788^{\circ}$

ตอร...

6784

ored.

sxes:.

5xesti:

$8770.5^{\circ}$

tiet". $\because:$ ac:

4.0
-4.83

$-8.0^{\circ}$

$1.0^{\circ}$

$60^{\circ}$

(a):

$\rightarrow 217.5$.

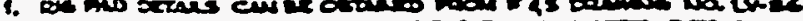

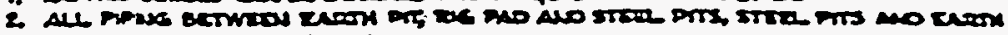

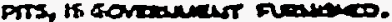

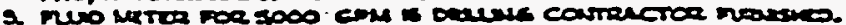

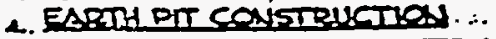

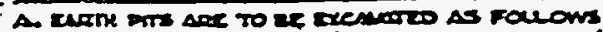

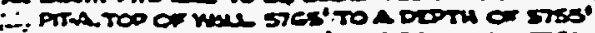

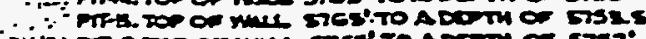

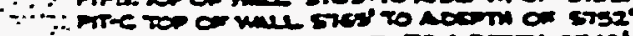

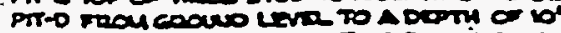

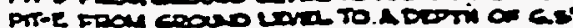

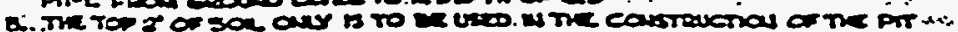

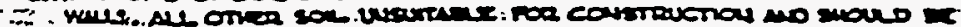

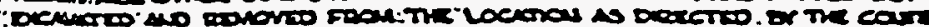

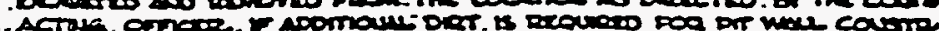

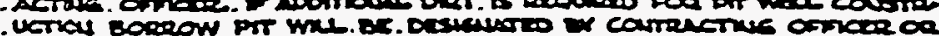

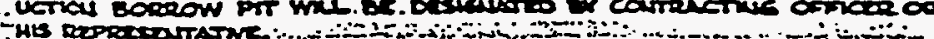

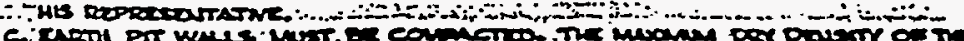

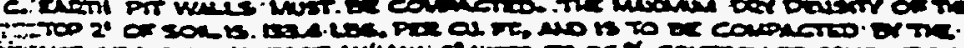

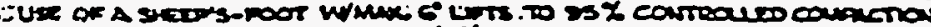

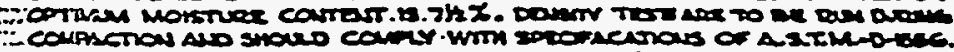

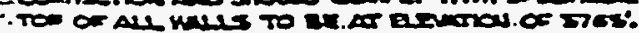

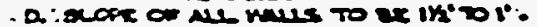

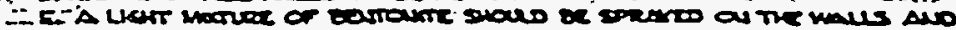

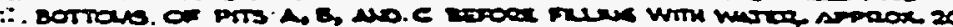

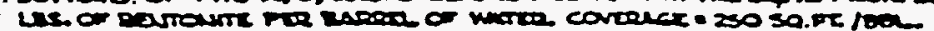

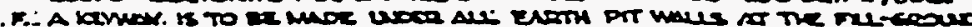

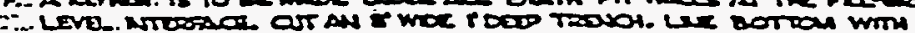

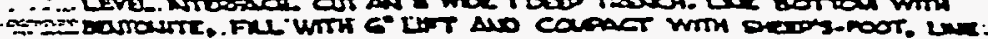

-

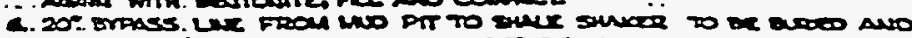

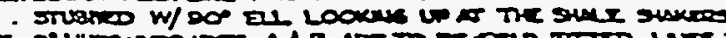

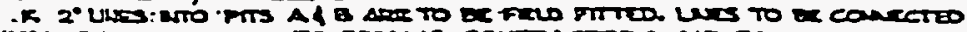

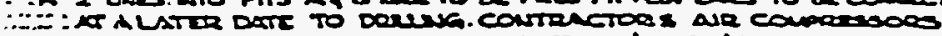

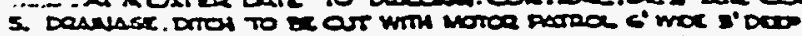

C. CONCRFTE H PAD.

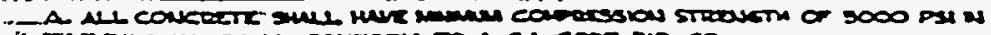

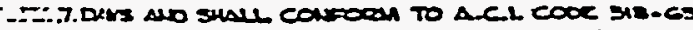

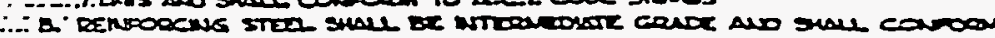

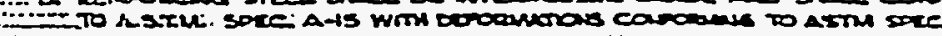

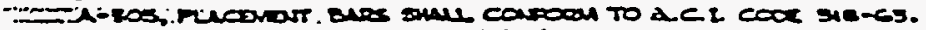

7: PIPINEI INSTALIATIOA

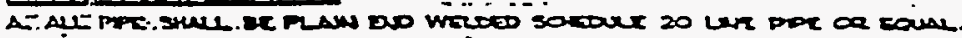
A. Ail vives Aace Fusweo

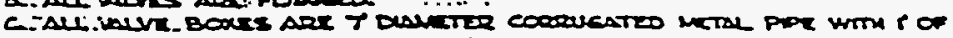
= Loose conara w Bortou.

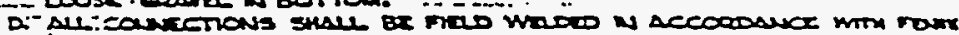

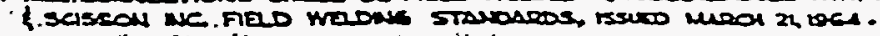

\section{BUL OF MATERLIS}

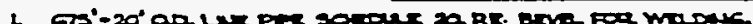

-2. 7 FA

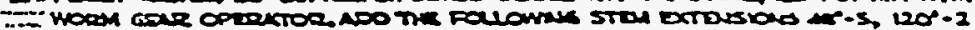

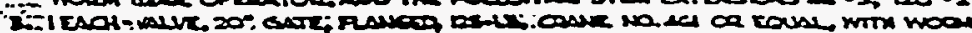
- cen copotor

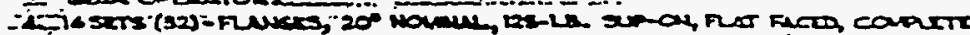

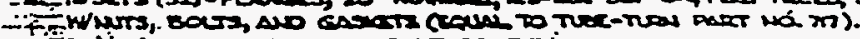

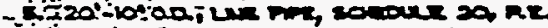

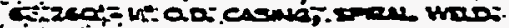

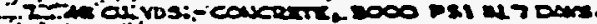

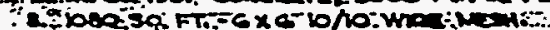

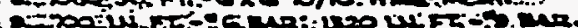

D-2

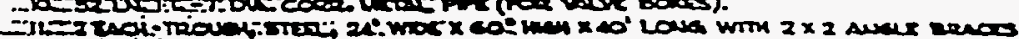

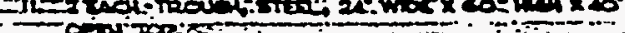

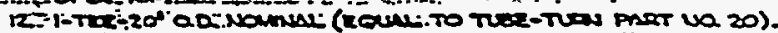

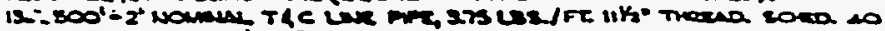

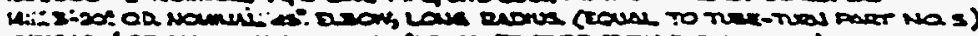

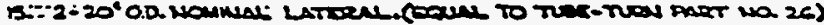

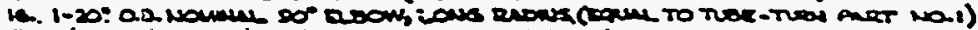

\begin{tabular}{|c|c|c|c|c|c|}
\hline & & - & & & \\
\hline & & & & & \\
\hline & . & 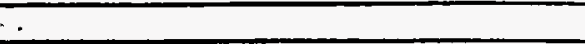 & & & \\
\hline & & & & & \\
\hline & & & & & \\
\hline 1. & Eaned & 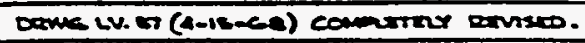 & 5.2 & स2 & \\
\hline$m$ & $m \pi$ & mencons & - & $d$ & \\
\hline
\end{tabular}

T. U. ATOMIC ENERGY COMMISSION

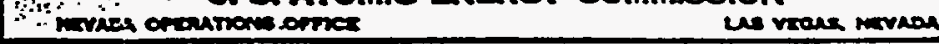

J. Gises

IREZS.

Therionand

MUD PITS \& SECTIONS

inistat

(1)

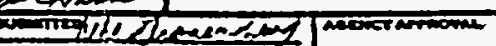

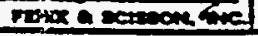

Fratx a scieson, INC.

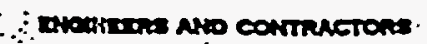

\begin{tabular}{|c|c|c|}
\hline & $U C-3$ \\
\hline & $5 V-87$ & 1 \\
\hline
\end{tabular}




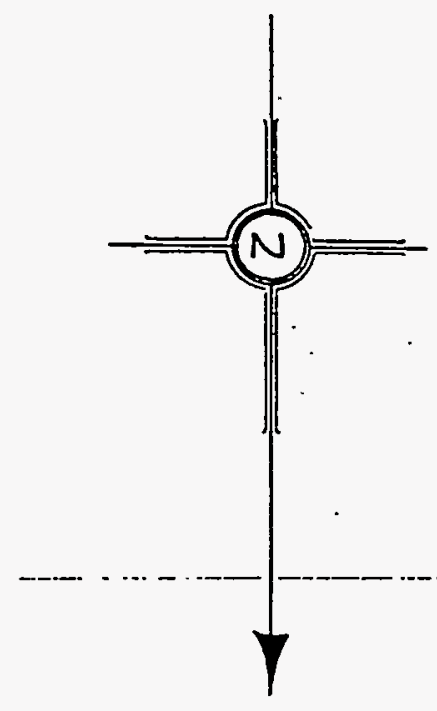

posunc5 Diro
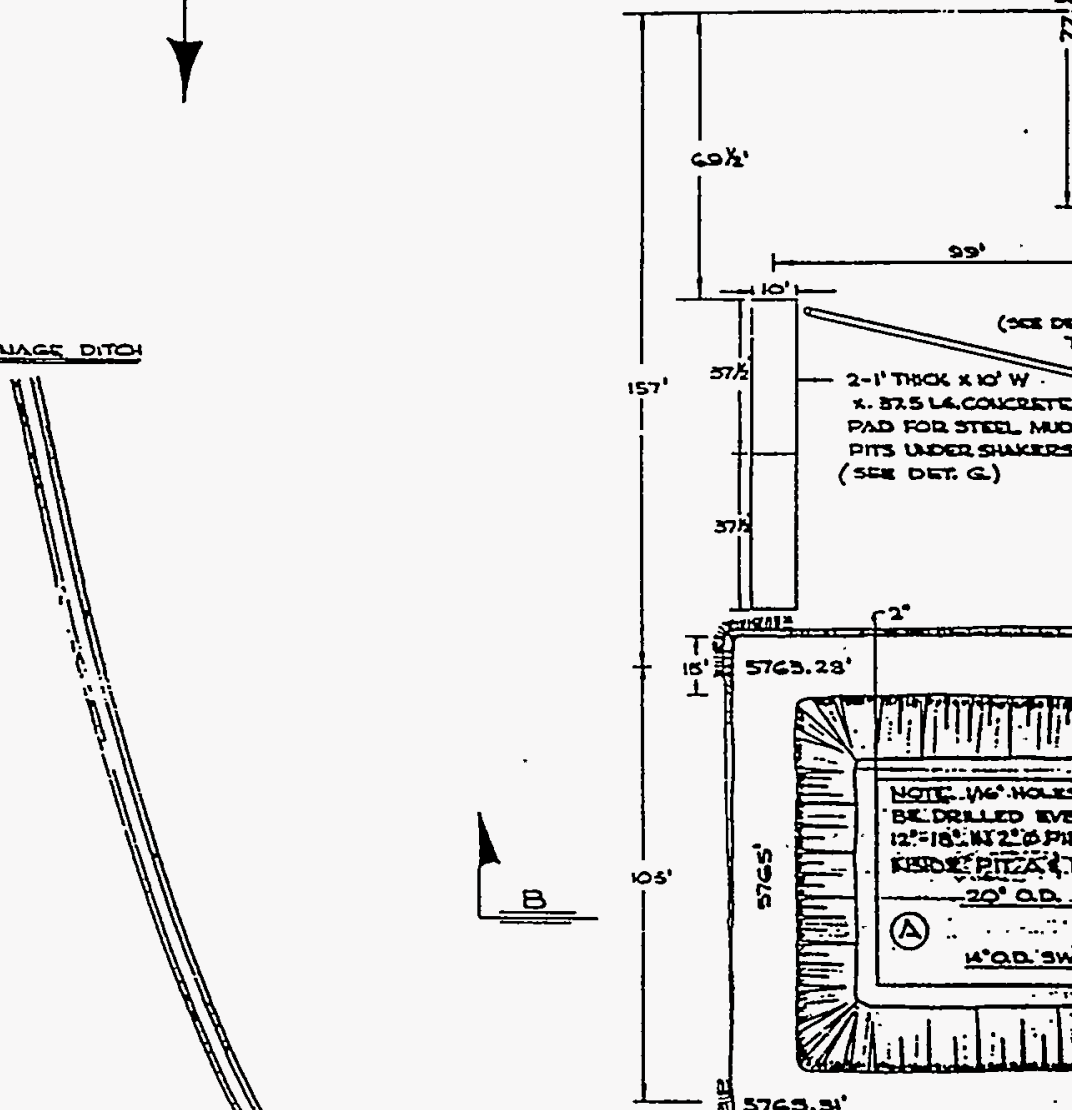

8

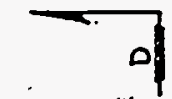

.

$100^{\prime}$

Gilst.

:

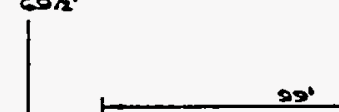

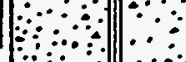
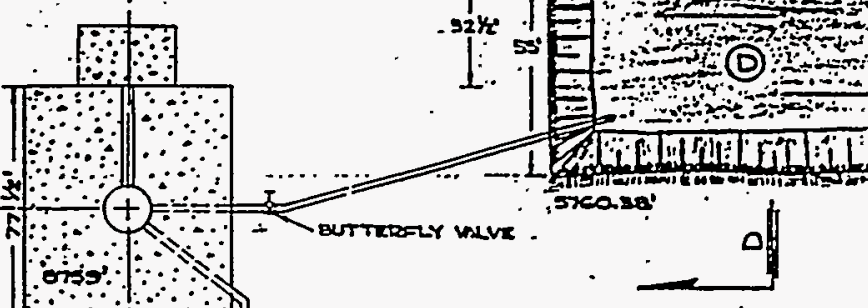

$\because \because$

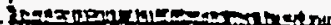

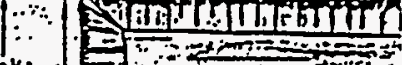

$22 \%=\frac{1}{10}=0$

L. 1 -

0

-

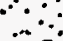

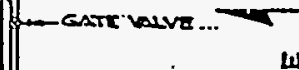

w)

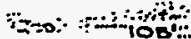

sxcl.22"

-
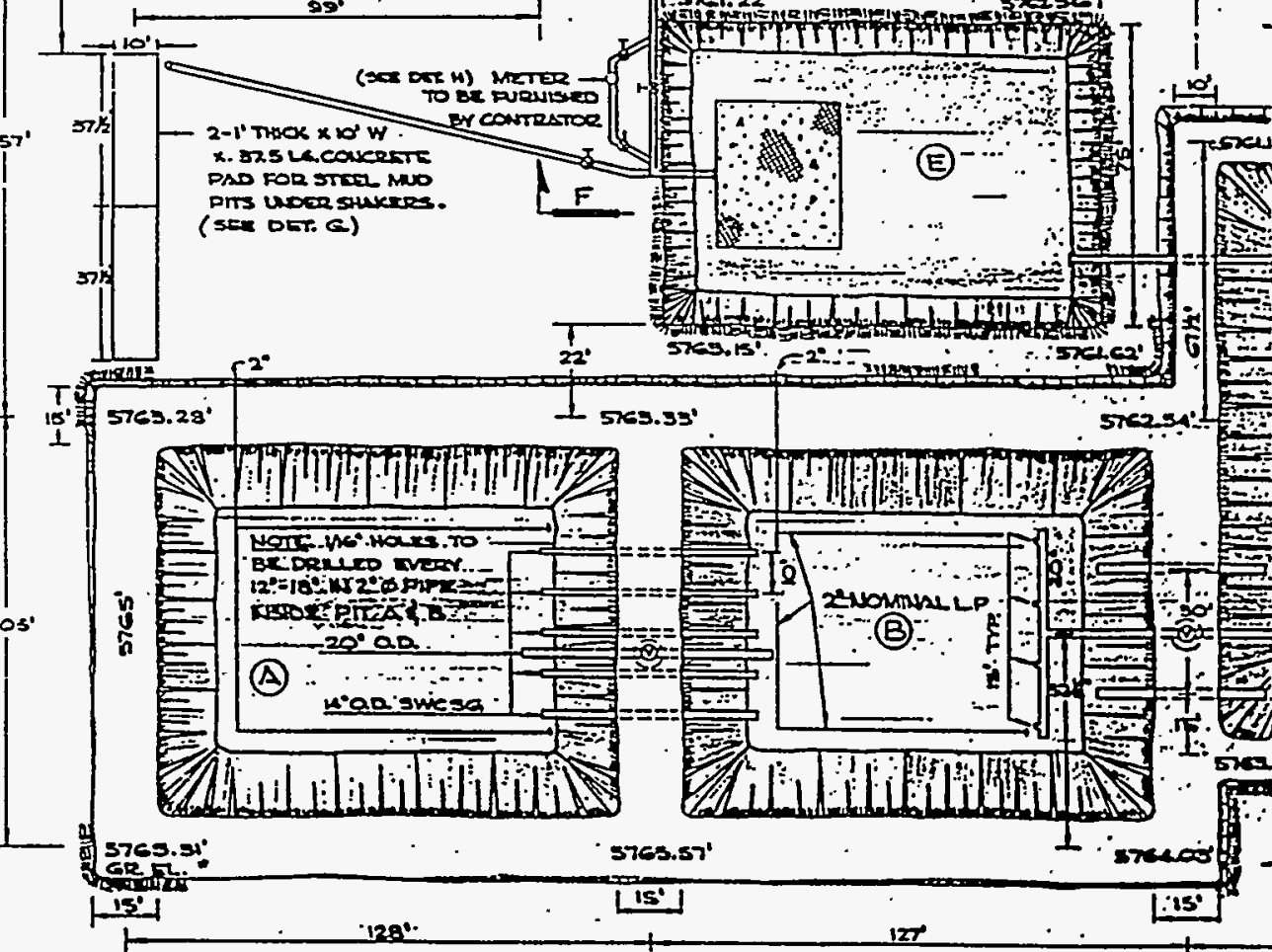

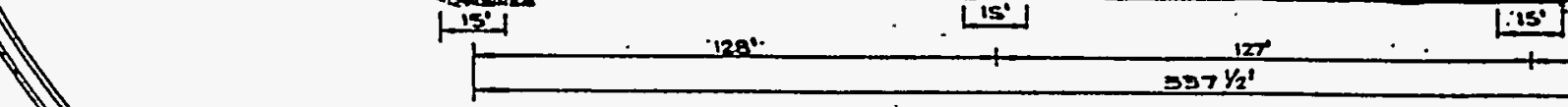

14
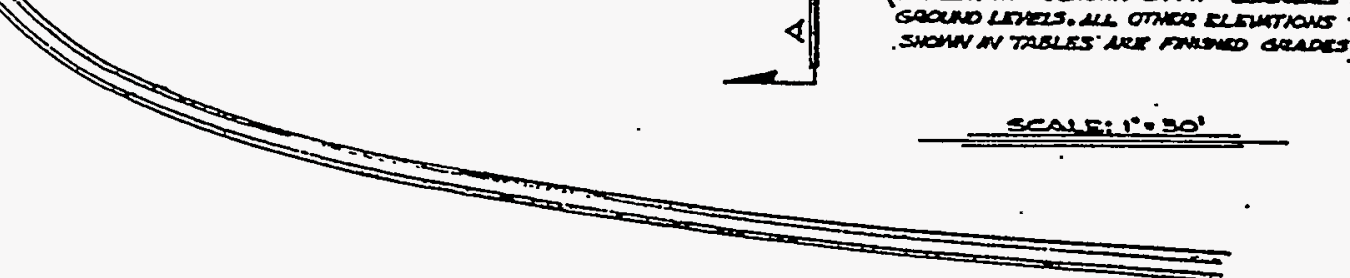


\section{Appendix C}

\section{Sampling and Analysis Design}




\section{Table of Contents}

C.1.0 Optimization of the Design for Collecting Data $\ldots \ldots \ldots \ldots \ldots \ldots \ldots \ldots \ldots$ C-1

C.1.1 Statistical Design for Inside Mud Pits $\ldots \ldots \ldots \ldots \ldots \ldots \ldots \ldots \ldots \ldots \ldots \ldots$

C.1.1.1 Sampling Approach for Inside Mud Pits $\ldots \ldots \ldots \ldots \ldots \ldots \ldots$ C-3

C.1.1.2 Sampling Approach for Outside Mud Pits . ............. C-6

C.1.2 Shaker Pad Areas . .............................. 6

C.1.2.1 Drilling Mud/Grout Piles $\ldots \ldots \ldots \ldots \ldots \ldots \ldots \ldots \ldots \ldots \ldots \ldots \ldots \ldots$

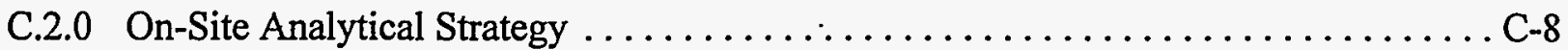

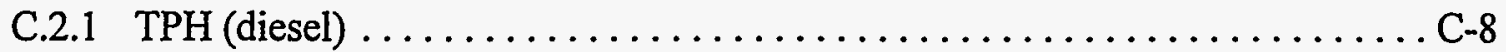

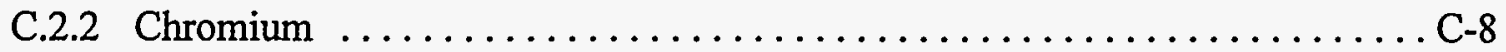

C.2.3 Decision Rules for Chromium Analyses $\ldots \ldots \ldots \ldots \ldots \ldots \ldots \ldots \ldots$ C-10 


\section{C.1.0 Optimization of the Design for Collecting Data}

\section{C.1.1 Statistical Design for Inside Mud Pits}

The sampling program for the mud pits has been designed to provide sufficient data to allow statistical determination of whether targeted analytes are present in the mud pits in concentrations that exceed preliminary action levels. This determination will be made using the procedures described in Chapter 6 of the EPA publication Methods for Evaluating the Attainment of Cleanup Standards, Volume 1: Soils and Solid Media (EPA, 1989). For each mud pit, the mean concentration (or activity for radionuclides in the UC-1 mud pits) and standard deviation of each targeted analyte in the mud pit soils will be used to calculate the number of samples necessary to make that determination at the 90 percent confidence level (equivalent to the decision error rate goal discussion in Section 3.4.6.1 of the CAIP) using the following equation (equation 6.6 from the EPA, 1989, document).

\section{Equation 1}

$$
n_{d}=s^{2}\left(\frac{z_{1-\beta}+z_{1-\alpha}}{C s-\mu_{1}}\right)^{2}
$$

Where:

$$
\begin{aligned}
& \mathrm{n}_{\mathrm{d}}=\text { number of samples; } \\
& \mathrm{s}=\text { standard deviation of the sample population; } \\
& \alpha=\text { false positive rate; } \\
& \beta=\text { false negative rate; } \\
& \mathrm{z}_{1-\alpha}=\text { critical value for normal distribution with a probability of } 1-\alpha ; \\
& \mathrm{z}_{1-\beta}=\text { critical value for normal distribution with a probability of } 1-\beta ; \\
& \mathrm{Cs}=\text { the cleanup standard (or action level); and } \\
& \mu_{1}=\text { mean concentration of contaminant. }
\end{aligned}
$$

By using $z_{1-\alpha}$ and $z_{1-\beta}$ values (usually available from statistics text books) for $\alpha=\beta=0.10$ (the 10 percent decision error rate goal for the project), the number of samples that need to be - collected to make the determination at the 90 percent confidence level can be calculated. If the calculated number of samples is less than or equal to the number of samples actually collected, 
no additional samples would be required to support the decision with no more than a 10 percent chance of making a decision error. If the calculated number of samples is greater than the number actually collected, then either additional samples can be collected to meet the decision error goal, or the decision could be made with the level of confidence calculated for the number of samples collected.

The TPH analytical data collected in 1995 from the Central Mud Pit (Table 2-3 in the CAIP) can be used to illustrate the process. A total of ten samples was collected from the surface and nearsurface of the mud pit, four from the 0 - to 3-inch depth interval (samples 1A, 3A, 4A, and 5A), one from the 3- to 6-inch depth interval (sample 2A), one from the 18-to 21-inch depth interval, (sample 1B), and four from the 20- to 23-inch depth interval (samples $2 \mathrm{~B}$ through $5 \mathrm{~B}$ ). Assuming that the top two feet of the drilling mud is homogeneous (i.e., there is no stratification of TPH contamination, and the analytical results are representative of the top two feet of mud), the data can be used to calculate how many samples would be required to determine whether TPH concentrations in the top two feet of drilling mud exceed the TPH action level, with no more than a 10 percent chance of making a decision error ( $\alpha$ and $\beta=0.10$ ). The values for the equation variables are:

$\mu_{1}=376.9 \mathrm{mg} / \mathrm{kg}$ (the mean TPH concentration for the ten samples);

$\mathrm{s} \quad=258.77 \mathrm{mg} / \mathrm{kg}$ (the standard deviation for the ten samples);

$\dot{C s}=100 \mathrm{mg} / \mathrm{kg}$ (the preliminary action level for TPH, as discussed in Section 3.4.3.3 of the CAIP);

$\mathrm{z}_{1-\alpha}=1.282$ (for $\alpha=0.10$ ); and

$z_{1-\beta}=1.282$ (for $\beta=0.10$ ).

Using these values in the equation above, the number of samples needed to make the determination $\left(n_{d}\right)$ at the specified confidence level is 5.74 , rounded up to 6 . Since 10 samples were collected, no additional samples are needed to make the determination with no more than a 10 percent chance of a decision error (the determination would be that the mean concentration of TPH in the uppermost two feet of drilling mud exceeds the preliminary action level for TPH). It should be noted that the equation is applicable to normally distributed data. Although the distribution of data for the mud pits is unknown, Gilbert (1987) indicates that the arithmetic mean (normal distribution) is a reasonable estimator of the true mean when the coefficient of variation (sample standard deviation divided by sample mean) is less than 1.2. Since the 
coefficient of variation for the above example is approximately 0.93 , the assumption of normality appears to be reasonable.

It should be noted that the closer the mean concentration is to the action level, or the greater the standard deviation (or both), the greater the number of samples needed to make the - determination. In addition, the false positive $(\alpha)$ and false negative $(\beta)$ rates specified for the statistical calculations also affect the number of samples needed. As a result, the number of samples needed to make the determination for other mud pits may not be the same as the number needed for the top two feet of the Central Mud Pit.

\section{C.1.1.1 Sampling Approach.for Inside Mud Pits}

The sampling and analysis program for the CNTA mud pits is designed to support the statistical analysis described above. For each mud pit, the number of samples calculated for the top two . feet of the Central Mud Pit (six) will be used as a starting point for the number of locations to be sampled. Samples will be collected at two-foot intervals at each location in each mud pit to allow determination of whether contamination is stratified, with each two-foot depth increment in each mud pit treated as a separate layer for the purpose of the statistical evaluation (i.e., six samples will be collected from each two-foot depth interval in each mud pit). One sample also will be collected from the native soils below the mud pit at each sampling location.

Due to the lack of data for the mud pits other than the Central Mud Pit and the uncovered mud pit at UC-4, the actual number of samples-needed for each mud pit to support application of the decision rules at a 90 percent confidence level is unknown. The most efficient and cost-effective approach to addressing this uncertainty is to use field analytical methods because these methods will provide "real-time" data which will allow continuous calculation (or recalculation) of the number of samples needed to support application of the decision rules at the specified confidence level without having to wait for results from an off-site fixed laboratory. Due to the sensitivity of the statistical calculation to the difference between the mean measured concentration and the preliminary action level and to the standard deviation of the mean, it is important to select field analytical methods that are capable of measuring contamination at levels well below the preliminary action levels. Because of this, the field analytical method selected for the mud pit investigation is a mobile on-site laboratory capable of performing the same analytical method for TPH and chromium as an off-site fixed laboratory would use (SW-846 Method 8015 modified 
for TPH [EPA, 1996b], x-ray fluorescence spectrometry [XRF] and flame atomic absorption [FLAA] for total chromium [SW-846 Method 7190], and SW-846 Method 7196 for hexavalent chromium). An additional benefit of using the same method as an off-site lab would use is that the number of samples that need to be sent to an off-site fixed laboratory for confirmation analysis will be minimized.

Based on the available information, including the TCLP data from the 1995 DOE sampling event (Table 2-3 in the CAIP), the distribution of chromium concentrations with respect to whether it exceeds preliminary action levels is expected to closely follow the distribution of TPH concentrations. To confirm this assumption, chromium will be quantified on site by analytical methods designed to be definitive.

Based on these considerations, the general sampling and analysis approach for each mud pit is:

- Collect samples at two-foot depth intervals from six locations within each pit.

- Analyze the samples for TPH and hexavalent chromium at the mobile laboratory.

- For each two-foot depth interval, calculate the number of samples needed to determine whether the mean concentration of TPH or hexavalent chromium exceeds the preliminary action levels of $100 \mathrm{mg} / \mathrm{kg}$ and $400 \mathrm{mg} / \mathrm{kg}$, respectively.

- If the calculated number of samples is less than or equal to the number of samples actually collected, no additional samples will be needed to support application of the decision rules.

- If the calculated number of samples is greater than the number actually collected, but is less than nine, collect additional samples from the depth interval so that the number actually collected is equal to the number calculated.

- If the calculated number of samples is greater than the number actually collected, but is greater than nine, collect additional samples from the depth interval so that the total number actually collected is nine.

- Recalculate the number of samples needed.

- Repeat the sequence of sample collection, analysis, and recalculation of the number of samples needed until the calculated number of samples is less than or equal to the number of samples collected, or a total of nine samples have been collected. 
The upper limit of nine locations per mud pit is intended to allow evaluation of other options in addition to continued sampling to support application of the decision rules. These options include:

- Continue sampling until the calculated number of samples is equal to or less than the number collected.

- Modify the decision error goals so that the.calculated number of samples is equal to or less than the number collected.

- If one sample concentration is significantly greater than (or less than) the concentrations in the other samples from the depth interval, treat the one concentration as an outlier.

- Base a decision for the depth interval on data from the adjacent depth intervals. For example, if the data from the interval immediately above supports an "exceeds action levels" decision, and the data from the depth intervals below support a "does not exceed action levels" decision, a decision could be made to include the uncertain depth interval with the overlying "exceeds action levels" interval(s) for the purpose of evaluating remedial options.

A flow chart showing the decision process for each two-foot depth interval for each mud pit is presented in Figure 3-1 in the CAIP.

The samples collected from the native soils below the mud pits will be archived at the mobile laboratory (for TPH and hexavalent chromium analysis). If the deepest sample of drilling mud at a sampling location contains TPH and/or hexavalent chromium above their respective preliminary action levels, these archived samples will be analyzed to allow evaluation of whether the contaminant has migrated into the native soils. In addition, for each mud pit three samples representing the depth interval(s) where TPH and/or hexavalent chromium exceeds its preliminary action level will be sent to a fixed off-site laboratory for TCLP-extractable volatile and semivolatile organic compound and metals analyses to allow evaluation of remedial options.

As noted in Section C.1.1, additional samples for TPH analysis are not needed from the top two feet of the Central Mud Pit. As a result, samples collected from the top two feet of that pit will be analyzed for hexavalent chromium only in accordance with the procedure described in Section C.1.3. 


$$
\text { .. }
$$

In addition, it is unknown whether the small mud pit near the Central Mud Pit (CAS No. 58-09-02) and the mud pit near HTH-1 (CAS No. 58-09-04) actually are mud pits or whether they are borrow pits (until decided otherwise, they will be referred to as mud pits). Two samples will be collected from the small mud pit near the Central Mud Pit and three from the mud pit near HTH-1 for TPH and hexavalent chromium analysis by the mobile laboratory. If the samples collected from these pits physically appear to be the same material as is contained in the known mud pits or if TPH or hexavalent chromium is detected in the samples above its preliminary action level, the sampling and analysis process described above will be implemented in these pits. If it is determined that the material in these pits is not drilling mud, no further sampling will be performed.

\section{C.1.1.2 Sampling Approach for Outside Mud Pits}

Because areas outside the mud pits are not delineated by engineered structures such as berms, a judgmental (biased) sampling design will be used. Once an area has been selected, as indicated in the decision rule for areas outside the mud pits, sampling will occur at two-foot depth

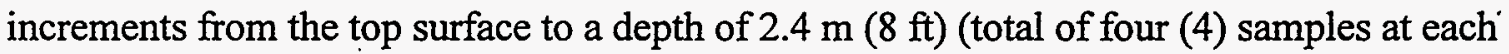
location) unless specific depth intervals are indicated by geophysical measurements. A set of such samples will be taken at five locations: one at the center of the suspected spill or overflow

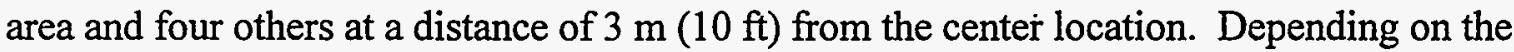
results of these 20 samples, additional samples at new locations and depths will be taken. Sampling will continue until the decision rule for TPH and hexavalent chromium indicates no further action. This may involve collection of samples at depths greater than $2.4 \mathrm{~m}(8 \mathrm{ft})$; however, the maximum depth of sample collection will be $6 \mathrm{~m}(20 \mathrm{ft})$. Once the horizontal and vertical limits of the contaminated area have been delineated, the statistical calculation used for inside of the mud pit berms will be used to verify that sufficient number of samples have been collected from within the contaminated area to support application of the decision rules.

\section{C.1.2 Shaker Pad Areas}

The shaker pad area investigation is designed to determine whether any of the spilled mud can be found and, if it is, to allow determination of whether targeted analytes are presented in concentrations that exceed preliminary action levels and determine the vertical and horizontal extent of the targeted analytes. The same statistical design as is described above for the mud pits will be used for each shaker pad area once the horizontal and vertical limits of the contaminated 
area have been established. The initial effort to locate the spilled mud will involve geophysical studies (described in Section 4.1).

Areas and depth intervals identified by the geophysical investigation or visual observations as potential locations of surficial or subsurface drilling mud will be sampled on a judgmental basis. Samples will be collected at two-foot increments from depth intervals identified by geophysical measurements. If no depth interval information is available, samples will be collected at twofoot increments from the ground surface to a depth of four feet at these locations. These samples will be analyzed for TPH and hexavalent chromium by the on-site mobile laboratory. If TPH and hexavalent chromium are not detected in any of the initial samples from a shaker pad area, no additional sampling will be conducted at that area. If TPH or hexavalent chromium is detected in any of the samples at an area, additional samples will be collected within the area identified by geophysical measurements, with the locations determined on a judgmental basis. These samples will be collected from the depth interval or intervals in which TPH or hexavalent chromium was detected and from the depth interval immediately underlying it. Sampling will proceed on a judgmental basis to determine the vertical and horizontal extent of the target analyte(s).

\section{C.1.2.1 Drilling Mud/Grout Piles}

The primary objective of the drilling mud/grout piles investigation is to determine whether the material present in the piles is drilling mud, cement grout, or a mixture of both. Because of this, the sampling approach is to collect two samples from each drilling mud/grout pile and analyze them for TPH and hexavalent chromium using the mobile laboratory. If TPH or hexavalent chromium is detected at levels that exceed their respective preliminary action level (see Section 3.4.3.3 of the CAIP) in either sample from a pile, an additional sample will be collected from that pile for off-site TCLP-extractable chromium to allow evaluation of disposal options. In addition, a visual inspection will be made of the pile area, and if evidence is found for migration of material or contaminants, then judgmental sampling of these areas will be conducted. If the material in any of the piles is solidified cement, that pile will not be sampled. 


\section{C.2.0 On-Site Analytical Strategy}

\section{C.2.1 TPH (diesel)}

Because the bottleneck in sample analysis most often occurs in the extraction process, it is imperative that the most effective technologies currently available be used to increase production, especially when operating on site in the ESC mode. For this reason, EPA method 3545, Accelerated Solvent Extraction (ASE), for sample extraction will be used on site (EPA, 1996b). This method will significantly increase overall sample throughput, minimize solvent waste, and increase overall production. TPH of the aliquots will be determined by EPA SW-846 Method 8015 modified (EPA, 1996b). Without a concentration step, 30-gram soil samples will provide a practical quantitation limit of 10 parts per million.

The daily throughput of TPH sample analysis (based on a 12-hour day) will be increased from 10 to 12 samples per day to approximately 15 to 18 samples per day. In addition, the automation of this system will help free an otherwise dedicated extractionist to assist with other tasks.

\section{C.2.2 Chromium}

The analysis of chromium will be performed using three methods based on the following rationale:

$X$-Ray Fluorescence -- As in the TPH analysis, sample throughput for metals analysis is equally important for this field investigation. For this reason, the Spectrace $6000 \mathrm{XRF}$ will be used for the analysis of total chromium. This analytical procedure requires minimal sample preparation, provides rapid turnaround times, has a dynamic range that corresponds to typical soil concentrations (from a few ppm to 100 percent), and furnishes accurate quantitative analysis.

This instrument is capable of accurately determining concentrations of chromium in soil with a practical quantitation limit of $20 \mathrm{mg} / \mathrm{kg}$ with a relative standard deviation (RSD) within 10 percent. Based on a preliminary action level of $400 \mathrm{mg} / \mathrm{kg}$, this instrument will be quite capable of accurately determining concentrations within the required range. Although there are no EPA approved methods for XRF, this instrument has been accepted by the EPA for generating both screening-level and definitive data. 
The method detection limit (MDL) for the XRF will be determined in general accordance with the procedures set forth in 40 CFR 136 Appendix A. However, because the matrices to be analyzed at CNTA are solids (soils and drilling mud), $100 \mathrm{mg} / \mathrm{kg}$ soil standards obtained from the National Institute of Standards and Technology will be used for the MDL determination rather than spiked, deionized water described in the CFR method.

Hexavalent Chromium by SW-846 Method 7196A -- Due to the potential for the presence of hexavalent chromium in the drilling mud and drilling mud-contaminated soils, the 24-hour holding time requirements for hexavalent chromium analysis, and the logistical difficulties in sample shipping from a remote site, this colorimetric analytical procedure will be used by the on-site laboratory. Prior to analysis, the samples will be digested using SW-846 Method 3060A (EPA, 1996b), which is a digestion method developed specifically for hexavalent chromium analysis of soils and other solid media.

Total Chromium by SW-846 Method 7190 -- The Flame Atomic Absorption (FLAA) method will be used to verify the total chromium analytical results from the XRF analyses. To determine the correlation between the FLAA and XRF chromium results, a total of 24 samples will be collected from the Central Mud Pit (a sample from four depths at each of six locations within the pit) and analyzed using both the FLAA and XRF methods. The FLAA and XRF chromium data from these samples will be used to perform a linear regression analysis between the FLAA and the XRF. The following are the decision rules to be applied based on the results of the regression analysis:

- If the regression coefficient ( $\mathrm{r}$ ) is greater than or equal to $0.95,1 / 5$ percent of all subsequent samples analyzed for chromium by XRF also will be analyzed by FLAA to verify the $\mathrm{XRF}$ results.

- If $r$ is greater than or equal to 0.9 , but less than $0.95,15$ percent of all subsequent samples analyzed for chromium by XRF also will be analyzed by FLAA to verify the XRF results.

- If $r$ is greater than 0.8 , but less than $0.9,30$ percent of all subsequent samples analyzed for chromium by XRF also will be analyzed by FLAA to verify the XRF results. 
- If $\mathrm{r}$ is greater than 0.7 , but less than or equal to $0.8,50$ percent of all subsequent samples analyzed for chromium by XRF also will be analyzed by FLAA to verify the XRF results.

- If $r$ is less than or equal to 0.7 , then use of the XRF will be discontinued, and all subsequent analyses for total chromium will be analyzed by FLAA.

The results of the subsequent XRF/FLAA split samples will be used to continuously reevaluate the correlation coefficient and apply the above decision rules. This will help to ensure that the total chromium data will be capable of supporting the decision-making process described in the next section.

\section{C.2.3 Decision Rules for Chromium Analyses}

As discussed in Section 3.4.3.3 of the CAIP, the preliminary action level for chromium is.based on the generic soil screening level for hexavalent chromium developed by EPA (EPA, 1996a). The analytical approach for the project has been designed to identify samples that will be analyzed for hexavalent chromium to allow application of the decision rules identified in Section 3.4.5.

The XRF (or FLAA if XRF data is poorly correlated with FLAA results) will be used to initially screen each sample collected for its total chromium concentration. If the chromium concentration determined by XRF is greater than $300 \mathrm{mg} / \mathrm{kg}$, the sample will be analyzed for hexavalent chromium by the on-site laboratory. The trigger level of $300 \mathrm{mg} / \mathrm{kg}$ has been selected as a conservative measure to ensure that samples with total chromium concentrations of close to, but below, the preliminary action level will be analyzed for hexavalent chromium. 


\section{Distribution List}

\section{Copies}

Janet Appenzeller-Wing

8

DOE/Nevada Operations Office

P.O. Box 98518, M/S 505

Las Vegas, NV 89193-85i8

Nevada Department of Environmental Protection

1515 East Tropicana

Las Vegas, NV 89119

Nevada Department of Environmental Protection

1

Capital Complex

Carson City, NV 89710

2

Paul Gretsky

IT Corporation

4330 S. Valley View Blvd., Ste. 114

Las Vegas, NV 89103 